\title{
Timing of Introduction of Complementary Foods and Beverages and Bone Health: A Systematic Review
}

The Pregnancy and Birth to 24 Months Project

Published date: April 15, 2019

Nutrition Evidence Systematic Review

Center for Nutrition Policy and Promotion

Food and Nutrition Service

U.S. Department of Agriculture

3101 Park Center Drive

Alexandria, Virginia 
This systematic review was conducted for the Pregnancy and Birth to 24 Months Project (P/B-24 Project) by the Nutrition Evidence Systematic Review (NESR) team at the Center for Nutrition Policy and Promotion, Food and Nutrition Service, USDA. All systematic reviews from the P/B-24 Project are available on the NESR website: https://nesr.usda.gov.

Conclusion statements drawn as part of this systematic review describe the state of science related to the specific question examined. Conclusion statements do not draw implications, and should not be interpreted as dietary guidance.

The contents of this document may be used and reprinted without permission. Endorsements by NESR, the Center for Nutrition Policy and Promotion, the Food and Nutrition Service, or the U.S. Department of Agriculture (USDA) of derivative products developed from this work may not be stated or implied.

In accordance with Federal civil rights law and USDA civil rights regulations and policies, the USDA, its Agencies, offices, and employees, and institutions participating in or administering USDA programs are prohibited from discriminating based on race, color, national origin, religion, sex, gender identity (including gender expression), sexual orientation, disability, age, marital status, family/parental status, income derived from a public assistance program, political beliefs, or reprisal or retaliation for prior civil rights activity, in any program or activity conducted or funded by USDA (not all bases apply to all programs). Remedies and complaint filing deadlines vary by program or incident.

Persons with disabilities who require alternative means of communication for program information (e.g., Braille, large print, audiotape, American Sign Language, etc.) should contact the responsible Agency or USDA's TARGET Center at (202) 720-2600 (voice and TTY) or contact USDA through the Federal Relay Service at (800) 877-8339. Additionally, program information may be made available in languages other than English.

To file a program discrimination complaint, complete the USDA Program Discrimination Complaint Form, AD3027, found online at How to File a Program Discrimination Complaint and at any USDA office or write a letter addressed to USDA and provide in the letter all of the information requested in the form. To request a copy of the complaint form, call (866) 632-9992. Submit your completed form or letter to USDA by: (1) mail: U.S. Department of Agriculture, Office of the Assistant Secretary for Civil Rights, 1400 Independence Avenue, SW, Washington, D.C. 20250-9410; (2) fax: (202) 690-7442; or (3) email: program.intake@usda.gov.

USDA is an equal opportunity provider, employer, and lender.

Suggested citation for this systematic review: Nutrition Evidence Systematic Review Team and Complementary Feeding Technical Expert Collaborative. Timing of Introduction of Complementary Foods and Beverages and Bone Health: A Systematic Review. Pregnancy and Birth to 24 Months Project. Alexandria, VA: U.S. Department of Agriculture, Food and Nutrition Service, Center for Nutrition Policy and Promotion, February 2019. Available at: https://nesr.usda.gov/project-specific-overview-pb-24-0

This systematic review has also been published in the American Journal of Clinical Nutrition: Obbagy JE, English LK, Wong YP, Butte NF, Dewey KG, Fox MK, et al. Complementary feeding and bone health: a systematic review. Am J Clin Nutr. 2019:872S-8S. doi: 10.1093/ajcn/nqy227.

Related citations are published in the American Journal of Clinical Nutrition:

- P/B-24 Project overview: Stoody EE, Spahn JM, Casavale KO. The Pregnancy and Birth to 24 Months Project: a series of systematic reviews on diet and health. Am J Clin Nutr. 2019;109(7):685S97S. doi: 10.1093/ajcn/nqy372.

- P/B-24 systematic review methodology: Obbagy JE, Spahn JM, Wong YP, Psota TL, Spill MK, Dreibelbis C, et al. Systematic review methodology used in the Pregnancy and Birth to 24 Months Project. Am J Clin Nutr. 2019;109(7):698S-704S. doi: 10.1093/ajcn/nqy226.

- Related systematic reviews from the P/B-24 Project:

o English LK, Obbagy JE, Wong YP, Butte NF, Dewey KG, Fox MK, et al. Timing of introduction of complementary foods and beverages and growth, size, and body composition: a systematic review. Am J Clin Nutr. 2019;109(7):935S-55S. doi: 10.1093/ajcn/nqy267. 
o English LK, Obbagy JE, Wong YP, Butte NF, Dewey KG, Fox MK, et al. Types and amounts of complementary foods and beverages consumed and growth, size, and body composition: a systematic review. Am J Clin Nutr. 2019;109(7):956S-77S. doi: 10.1093/ajcn/nqy281.

o English LK, Obbagy JE, Wong YP, Butte NF, Dewey KG, Fox MK, et al. Complementary feeding and developmental milestones: a systematic review. Am J Clin Nutr. 2019;109(7):879S-89S. doi: 10.1093/ajcn/nqy321.

o Obbagy JE, English LK, Psota TL, Wong YP, Butte NF, Dewey KG, et al. Complementary feeding and micronutrient status: a systematic review. Am J Clin Nutr. 2019;109(7):852S71S. doi: 10.1093/ajen/nqy266.

o Obbagy JE, English LK, Wong YP, Butte NF, Dewey KG, Fleischer DM, et al. Complementary feeding and food allergies, atopic dermatitis and eczema, asthma, and allergic rhinitis: a systematic review. Am J Clin Nutr. 2019;109(7):890S-934S. doi: 10.1093/ajcn/nqy220.

o Obbagy JE, English LK, Wong YP, Butte NF, Dewey KG, Fox MK, et al. Complementary feeding and bone health: a systematic review. Am J Clin Nutr. 2019:872S-8S. doi: 10.1093/ajcn/nqy227. 


\section{ACKNOWLEDGEMENTS}

\section{Complementary Feeding Technical Expert Collaborative (TEC):}

- Nancy F. Butte, PhD, RD, United States Department of Agriculture /Agricultural Research Service, Children's Nutrition Research Center, Baylor College of Medicine, Department of Pediatrics, Emeritus

- Kathryn G. Dewey, PhD, University of California, Davis, Department of Nutrition

- David M. Fleischer, MD, Children's Hospital Colorado, University of Colorado School of Medicine, Department of Pediatrics, Section of Allergy and Immunology

- Mary Kay Fox, Med, Mathematica Policy Research

- Frank R. Greer, MD, University of Wisconsin School of Medicine and Public Health, Department of Pediatrics, Emeritus

- Nancy F. Krebs, MD, MS, University of Colorado School of Medicine, Department of Pediatrics

- Kelley S. Scanlon, PhD, RD, United States Department of Agriculture, Food and Nutrition Service (formerly of the Centers for Disease Control and Prevention, Division of Nutrition, Physical Activity, and Obesity)

\section{Nutrition Evidence Systematic Review (NESR) team:}

- Julie E. Obbagy, PhD, RD USDA, Lead Analyst (05/2016-project completion)

- Laural K. Englishi, PhD, Panum Group, Analyst (11/2016-project completion)

- Tricia L. Psota, USDA, Lead Analyst (07/2015-06/2016)

- Perrine Nadaudi, MS, Panum Group, Analyst (07/2015-05/2016)

- Kirsten Johnsi, MS, USDA, Panum Group, Analyst (07/2015-05/2016)

- Yat Ping Wong, MLS, MPH, USDA, Librarian

- Nancy Terry, MLS, NIH, Librarian

\section{Project Lead:}

- Eve Essery Stoody, PhD, USDA

\section{Federal Expert Group (FEG)-Technical Expert Collaborative (TEC) Liaisons:}

- Kelley S. Scanlon, PhD, RD, United States Department of Agriculture, Food and Nutrition Service (formerly of the Centers for Disease Control and Prevention, Division of Nutrition, Physical Activity, and Obesity)

All TEC and NESR team members, Project leads, and FEG-TEC liaisons participated in establishing the research questions, analytic framework, and study inclusion and exclusion criteria. JEO, LKE, TLP, PN, KJ, YWP, and NT developed and conducted the literature search, screened search results, and identified studies for inclusion. JEO and LKE extracted data and assessed risk of bias for included studies. NFC, KGD, MKF, FRG, NFK, DF and KSS reviewed and provided substantive feedback on all systematic review materials, including the synthesis of the body of evidence, conclusion statement,

i Under contract with the Food and Nutrition Service, United States Department of Agriculture. 
and grade of the strength of the evidence. JEO prepared this report and EES provided oversight. All authors critically reviewed and approved the final report. The authors declare no conflicts of interest.

FUNDING SOURCE: United States Department of Agriculture, Food and Nutrition Service, Center for Nutrition Policy and Promotion, Alexandria, VA 


\section{TABLE OF CONTENTS}

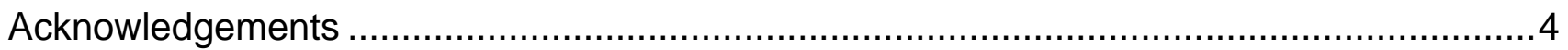

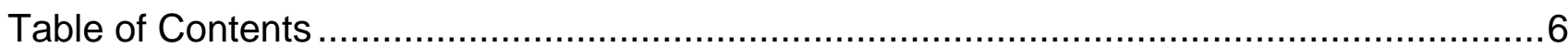

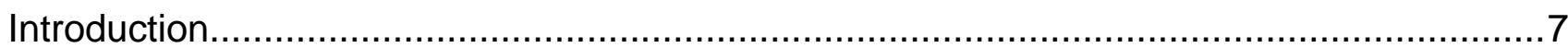

What is the relationship between timing of introduction of complementary foods/beverages

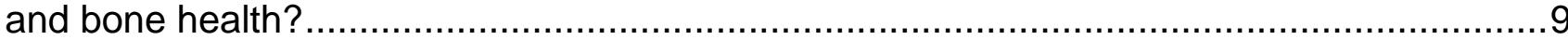

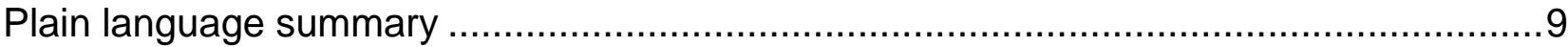

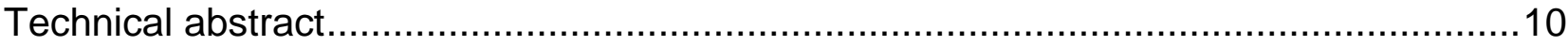

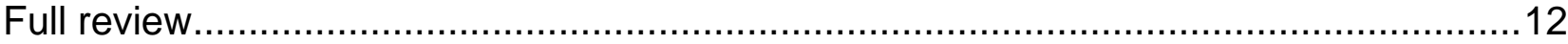

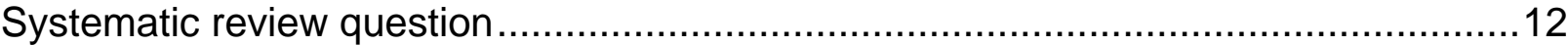

Conclusion statement

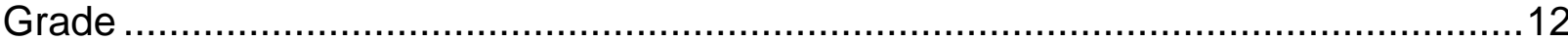

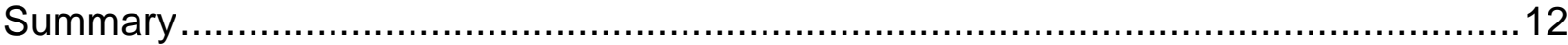

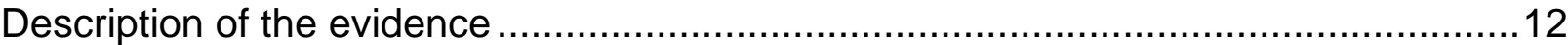

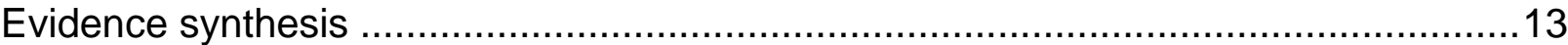

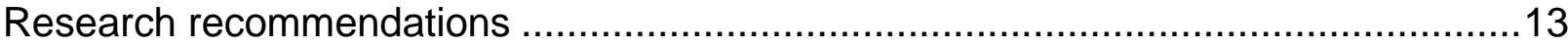

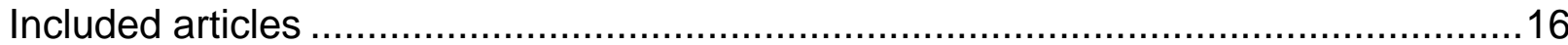

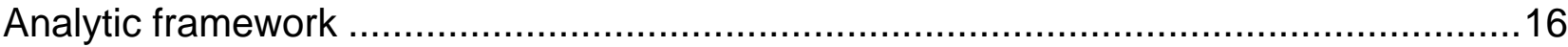

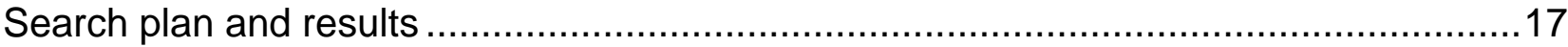

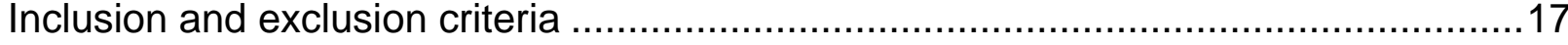

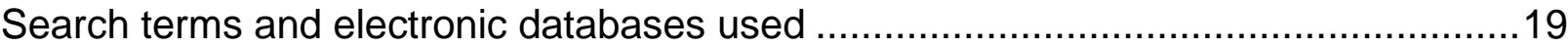

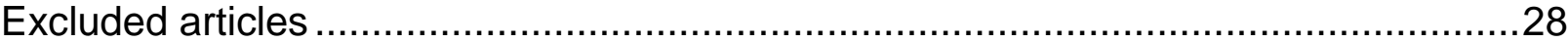

Table 1. Description of evidence on timing of introduction of complementary foods and

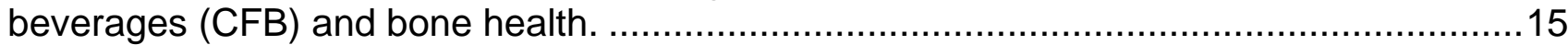

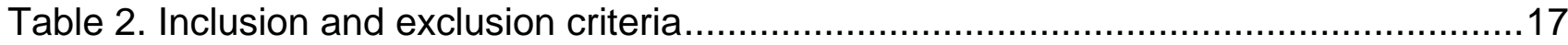

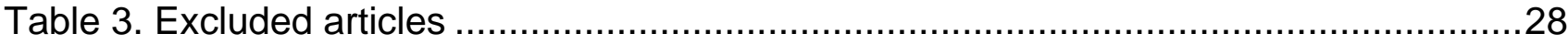

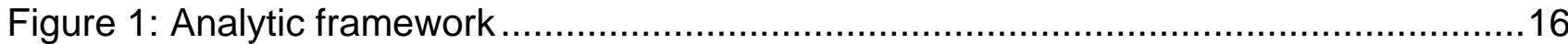

Figure 2: Flow chart of literature search and screening results ...................................26 
This document describes a systematic review conducted to answer the following question: What is the relationship between timing of introduction of complementary foods and beverages and bone health? This systematic review was conducted as part of the Pregnancy and Birth to 24 Months (P/B-24) Project by USDA's Nutrition Evidence Systematic Review (NESR).

The purpose of the P/B-24 Project was to conduct a series of systematic reviews on diet and health for women who are pregnant and for infants and toddlers from birth to 24 months of age. This project was a joint initiative led by USDA and HHS, and USDA's NESR carried out all of the systematic reviews. A Federal Expert Group (FEG), a broadly representative group of Federal researchers and program leaders, also provided input throughout the P/B-24 Project. More information about the P/B-24 Project has been published ${ }^{i i}$ and is available on the NESR website: https://nesr.usda.gov/project-specificoverview-pb-24-0.

NESR, formerly known as the Nutrition Evidence Library (NEL), specializes in conducting food- and nutrition-related systematic reviews using a rigorous, protocol-driven methodology. To conduct each P/B-24 systematic review, NESR's staff worked with a Technical Expert Collaborative (TEC), which is a group of 7-8 leading subject matter experts.

NESR's systematic review methodology involves developing and prioritizing systematic review questions, searching for and selecting studies, extracting and assessing the risk of bias of data from each included study, synthesizing the evidence, developing a conclusion statement, grading the evidence underlying the conclusion statement, and recommending future research. A detailed description of the methodology used in conducting systematic reviews for the P/B-24 Project has been publishediii and is available on the NESR website: https://nesr.usda.gov/pb-24-project-methodology-0. In addition, starting on page 16, this document includes details about the methodology as it was applied to the systematic review described herein. An analytic framework that illustrates the overall scope of the question, including the population, the interventions and/or exposures, comparators, and outcomes of interest is found on page 16. In addition, the literature search plan, that was used to identify studies included in this systematic review, is found on page 16.

\footnotetext{
ii Stoody EE, Spahn JM, Casavale KO. The Pregnancy and Birth to 24 Months Project: a series of systematic reviews on diet and health. Am J Clin Nutr. 2019;109(7):685S-97S. doi: 10.1093/ajcn/nqy372.

iii Obbagy JE, Spahn JM, Wong YP, Psota TL, Spill MK, Dreibelbis C, et al. Systematic review methodology used in the Pregnancy and Birth to 24 Months Project. Am J Clin Nutr. 2019;109(7):698S-704S. doi: 10.1093/ajcn/nqy226.
} 


\section{List of abbreviations}

\begin{tabular}{ll}
\hline Abbreviation & Full name \\
\hline aBMC & Area-adjusted bone mineral content \\
\hline BA & Bone area \\
\hline BMC & Bone mineral content \\
\hline BMD & Bone mineral density \\
\hline FEG & Complementary food and beverages \\
\hline HHS & Federal Expert Group \\
\hline NEL & Department of Health and Human Services \\
\hline NESR & Nutrition Evidence Library \\
\hline NIH & Nutrition Evidence Systematic Review \\
\hline P/B-24 & National Institutes of Health \\
\hline PTH & Pregnancy and Birth to 24 Months Project \\
\hline TEC & Parathyroid hormone \\
\hline USDA & Technical Expert Collaborative \\
\hline
\end{tabular}




\section{WHAT IS THE RELATIONSHIP BETWEEN TIMING OF INTRODUCTION OF COMPLEMENTARY FOODS/BEVERAGES AND BONE HEALTH?}

\section{PLAIN LANGUAGE SUMMARY}

What is the question?

- The question is: What is the relationship between timing of introduction of complementary foods and beverages and bone health?

What is the answer to the question?

- Insufficient evidence is available to draw conclusions about the relationship between the timing of introduction of complementary foods and beverages and bone health.

Why was this question asked?

- This important public health question was identified and prioritized as part of the U.S. Department of Agriculture and Department of Health and Human Services Pregnancy and Birth to 24 Months Project.

How was this question answered?

- A team of Nutrition Evidence Systematic Review staff conducted a systematic review in collaboration with a group of experts called a Technical Expert Collaborative

What is the population of interest?

- Generally healthy infants and toddlers who were fed complementary foods and beverages from ages 0-24 months and had bone health examined through 18 years of age.

What evidence was found?

- This review includes 3 studies.

- These studies compared the age when complementary foods and beverages were first introduced and bone health.

- Complementary foods and beverages are foods and beverages other than human milk or infant formula provided to an infant or young child.

- There are limitations in the evidence as follows: only a few studies were done, and they varied too much to be able to answer the question.

How up-to-date is this review?

- This review includes literature from 1/1980 to 7/2016. 


\section{TECHNICAL ABSTRACT}

\section{Background}

- Complementary feeding is the process that starts when human milk or infant formula is complemented by other foods and beverages, beginning during infancy and typically continuing to 24 months of age.

- This systematic review was conducted by the Nutrition Evidence Systematic Review (NESR) team as part of the U.S. Department of Agriculture and Department of Health and Human Services Pregnancy and Birth to 24 Months Project.

- The goal of this systematic review was to answer the following research question: What is the relationship between timing of introduction of complementary foods and beverages and bone health?

\section{Conclusion Statement and Grades}

- Insufficient evidence is available to draw conclusions about the relationship between the timing of introduction of complementary foods and beverages and bone health. Grade: [Grade Not Assignable]

\section{Methods}

- This systematic review was conducted by a team of staff from NESR in collaboration with a Technical Expert Collaborative.

- A literature search was conducted using 4 databases (CINAHL, Cochrane, Embase, and PubMed) to identify articles published from January 1980 to July 2016 that examined the age when complementary foods and beverages (CFB) were first introduced and bone health. CFB were defined as foods and beverages other than human milk or infant formula provided to an infant or young child. Bone health outcomes included bone, biomarkers of bone metabolism, and incidence and prevalence of osteoporosis, osteopenia, rickets, and fracture. A manual search was done to identify articles that may not have been included in the electronic databases searched. Articles were screened in a dual manner, independently by 2 NESR analysts, to determine which articles met predetermined criteria for inclusion.

- Data from each included article were extracted, risk of bias was assessed. The body of evidence was qualitatively synthesized, a conclusion statement was developed and the strength of the evidence (grade) was assessed using preestablished criteria including evaluation of the internal validity/risk of bias, adequacy, consistency, impact, and generalizability of available evidence. Research recommendations were identified.

\section{Summary of Evidence}

- Three studies met the inclusion criteria for this systematic review, one randomized controlled trial, one prospective cohort study, and one case-control study.

- The randomized controlled trial included a small sample of infants fed only vitamin D fortified infant formula, and did not follow infants long enough to assess the impact of timing of introduction to CFB and bone health, as outcomes were assessed when infants were 26 weeks (wk) of age. 
- The observational studies did not measure and/or account for a number confounding factors that could have impacted the relationship between timing of CFB introduction and bone health later in childhood.

- The ability to draw conclusions about the relationship between the timing of CFB introduction and bone health is limited by an overall lack of research, as well as heterogeneity in the three studies included in this systematic review with regards to methodology, subject populations, and results. 


\section{FULL REVIEW}

\section{Systematic review question}

What is the relationship between timing of introduction of complementary foods and beverages and bone health?

\section{Conclusion statement}

Insufficient evidence is available to draw conclusions about the relationship between the timing of introduction of complementary foods and beverages and bone health.

\section{Grade}

\section{Grade Not Assignable}

\section{Summary}

- Complementary foods and beverages (CFB) were defined as foods and/or beverages (liquids, semisolids, and solids) other than human milk or infant formula provided to an infant or young child to provide nutrients and energy. Fluid cow's milk consumed before 12 mo of age was not considered a CFB. This systematic review includes studies that examined the relationship between the timing of CFB introduction and bone health during childhood.

- Three studies published since 1980 met the inclusion criteria for this systematic review, one randomized controlled trial, one prospective cohort study, and one case-control study.

- The randomized controlled trial included a small sample of infants fed only vitamin $D$ fortified infant formula, and did not follow infants long enough to assess the impact of timing of introduction to CFB and bone health, as outcomes were assessed when infants were 26 weeks (wk) of age.

- The observational studies did not measure and/or account for a number confounding factors that could have impacted the relationship between timing of CFB introduction and bone health later in childhood.

- The ability to draw conclusions about the relationship between the timing of CFB introduction and bone health is limited by an overall lack of research, as well as heterogeneity in the three studies included in this systematic review with regards to methodology, subject populations, and results.

\section{Description of the evidence}

This systematic review includes three articles that examined the relationship between timing of introduction of complementary foods and beverages (CFB) and bone health during childhood (through 18 years of age) (Table 2) (1-3).

Bainbridge et al. (1) randomly assigned infants from the U.S., fed vitamin $D$ and ironfortified formula, to receive CFB (rice cereal) at 16 weeks (wk) or 26 wk. Results showed that infants who received CFB at 16 wk vs. 26 wk had significantly higher parathyroid hormone (PTH) concentrations at 26 wk and greater increases in PTH concentrations from 16 wk to 26 wk. However, there were no differences between groups in serum calcium (total and ionized), magnesium, phosphorous, osteocalcin, or alkaline phosphatase, bone width or bone mineral content of the forearm radius (at 26 
wk or change between 16 wk and 26 wk). The authors deemed the PTH finding clinically insignificant as serum calcium was similar between groups, and PTH levels were all within the normal reference range for infants.

van den Hooven et al. (2) grouped a cohort of infants from the Netherlands based on the age at first CFB ("solid foods") introduction: before 4 months (mo), 4 to $4.9 \mathrm{mo}, 5$ to $5.9 \mathrm{mo}$, or after 6 mo. Results showed that introduction of CFB before 4 vs. at 4 to 4.9 mo was significantly associated with higher BMD. In addition, introduction of CFB before 4 mo vs. at 4-4.9 mo was significantly associated with higher aBMC, but introduction of CFB between 5 and 5.9 vs. 4 to 4.9 mo was significantly associated with lower aBMC. Introduction of CFB between 5 and 5.9 vs. 4-4.9 mo was significantly associated with higher BA, while introduction of CFB after 6 mo vs. at 4 to 4.9 mo was significantly associated with lower BA. Finally, timing of CFB introduction was not associated with any significant differences in BMC.

Majid Molla et al. (3) examined children from Kuwait ( 15 mo of age) diagnosed with rickets (cases) vs. healthy controls, matched for age and socioethnic characteristics, comparing the age at which they were introduced to CFB. Diagnosis of rickets was based on a clinical exam, not confirmed by $x$-ray. Children with rickets were more likely to be fully swaddled (vs. partially) by mothers and breastfed through $6 \mathrm{mo}$, and had significantly lower serum vitamin D levels compared to controls. Results showed that significantly fewer rickets cases, compared to controls, received CFB before 6 mo compared to after $6 \mathrm{mo}$. However, confidence in these findings is limited due to lack of adjustment for key confounders (i.e., serum vitamin D, sunlight exposure, swaddling practices, or milk feeding practices).

\section{Evidence synthesis}

Only 3 studies published since 1980 examined the relationship between the timing of CFB introduction and bone health and met the criteria for inclusion in this systematic review. While the timing of CFB introduction compared in the studies was similar, there was considerable variation in outcome assessment, including the outcomes measured, the methods used to assess outcomes, the ages at which assessments were done (26 wk, $15 \mathrm{mo}$, and $6 \mathrm{y}$ ), and in findings reported.

In addition, a number of potential key confounders or effect modifiers were not consistently accounted for in the observational studies, such as: types and/or amount of CFB introduced and consumed, vitamin D supplementation, physical activity, socioeconomic status, and dietary intake that occurred between the time of CFB introduction and outcome assessment later in life. In particular, confidence in the findings reported by Majid Molla et al. (3) is severely limited as adjustments were not made for potential confounders that differed between cases and controls, including serum vitamin D levels, sunlight exposure, swaddling practices, or infant feeding practices.

Therefore, it is difficult to draw conclusions as to whether the age at which CFB is introduced impacts bone health.

\section{Research recommendations}

Given that evidence was insufficient to draw conclusions, additional research is needed to determine whether the age at which complementary feeding begins impacts bone health later in life. This includes research that addresses key gaps and limitations 
in the evidence, such as:

- Well-conducted and adequately powered studies that focus on timing of introduction of CFB containing nutrients that are likely to impact bone health

- Accounting for whether infants were fed breastmilk and/or infant formula, and other aspects of the overall diet quality consumed from the time at which CFB are introduced to the time when bone health is assessed, including whether infants received vitamin D supplements.

- Adjusting for key confounding factors in observational studies, including: education, socioeconomic status, race/ethnicity, child sex, gestational age, birth weight, growth pattern (or status), diet quality and vitamin D and calcium intake, sunlight exposure, and physical activity.

- Including diverse populations with varying racial/ethnic and socioeconomic backgrounds.

- Including sufficient duration of follow-up, through the second year of life and into childhood, to assess the longer term effects of complementary feeding on bone health, including functional outcomes (i.e., risk of fracture). 
Table 1. Description of evidence on timing of introduction of complementary foods and beverages (CFB) and bone health.

\begin{tabular}{|c|c|c|}
\hline $\begin{array}{l}\text { Reference; Study design; n; } \\
\text { country }\end{array}$ & Intervention or exposure & Results \\
\hline Bainbridge, 1996 (1) & $\begin{array}{l}\text { FF infants randomized to } \\
\text { receive CFB (rice cereal) at } \\
16 \text { weeks (wk) vs. no CFB } \\
\text { until } 26 \text { wk of age }\end{array}$ & Parathyroid hormone at 26wk: $18.2 \pm 6.2$ vs. $12.6 \pm 2.7 \mathrm{pg} / \mathrm{ml}, \mathrm{P}=0.04$ \\
\hline \multirow[t]{2}{*}{$\begin{array}{l}\text { Randomized Controlled Trial; } \\
\mathrm{n}=41 ; \text { United States }\end{array}$} & & $\begin{array}{l}\text { Parathyroid hormone change from } 16 \text { to } 26 \mathrm{wk}: 6.3 \pm 7.8 \text { vs. - } \\
4.8 \pm 3.3 \mathrm{pg} / \mathrm{ml}, \mathrm{P}=0.03\end{array}$ \\
\hline & & $\begin{array}{l}\text { Bone width radius (forearm), BMC (bone mineral content; forearm), } \\
\text { serum calcium (total and ionized), magnesium, phosphorous, } \\
\text { osteocalcin, alkaline phosphatase: No significant group differences }\end{array}$ \\
\hline Majid Molla, 2000 (3) & $\begin{array}{l}\text { Age of CFB introduction: } \\
\text { Mean age, mo }\end{array}$ & Rickets cases vs. controls: $8.12 \pm 3.32 \mathrm{mo}$ vs. $5.71 \pm 2.16 \mathrm{mo}, \mathrm{P}<0.0001$ \\
\hline $\begin{array}{l}\text { Case-Control Study; } 103 \\
\text { Cases of rickets, } 102 \text { Controls; } \\
\text { Kuwait }\end{array}$ & $\begin{array}{l}\text { Age of CFB introduction: } \\
>6 \mathrm{mo} \text {, percentage of cases } \\
\text { vs. controls }\end{array}$ & Rickets cases vs. controls: $26 \%$ vs $69 \% ; \mathrm{P}<0.001$ \\
\hline van den Hooven, 2016 (2) & $\begin{array}{l}\text { Age of CFB introduction: } \\
<4 \mathrm{mo}, 4-4.9 \mathrm{mo}, 5-5.9 \mathrm{mo} \\
\geq 6 \mathrm{mo}\end{array}$ & $\begin{array}{l}\text { Bone mineral density (BMD) at } 6 y:<4 \text { vs. } 4-4.9 \mathrm{mo}: \beta 4.10 \mathrm{mg} / \mathrm{cm}^{2} ; 95 \% \\
\mathrm{Cl}: 0.46,7.75 ; \mathrm{P}<0.05\end{array}$ \\
\hline \multirow[t]{5}{*}{$\begin{array}{l}\text { Prospective Cohort Study; } n= \\
4,919 ; \text { The Netherlands }\end{array}$} & & $\begin{array}{l}\text { Bone area (BA) at } 6 y: 5-5.9 \text { vs } 4-4.9 \mathrm{mo}: \beta 5.60 \mathrm{~cm}^{2} ; 95 \% \mathrm{Cl}: 1.13 \text {, } \\
\text { 10.07; } \mathrm{P}<0.05\end{array}$ \\
\hline & & BA at $6 y: \geq 6$ vs. $4-4.9 \mathrm{mo}: \beta-8.70 \mathrm{~cm}^{2} ; 95 \% \mathrm{Cl}:-13.85,-3.55 ; \mathrm{P}<0.01$ \\
\hline & & BMC at 6y: No significant associations with CFB introduction \\
\hline & & $\begin{array}{l}\text { Area-adjusted BMC (aBMC) at } 6 y:<4 \text { vs. } 4-4.9 \mathrm{mo}: \beta 4.06 \mathrm{~g} ; 95 \% \mathrm{Cl} \text { : } \\
0.18,7.94 ; \mathrm{P}<0.05\end{array}$ \\
\hline & & aBMC at $6 y: 5-5.9$ vs. $4-4.9 \mathrm{mo:} \beta-3.32 ; 95 \% \mathrm{Cl}:-6.50,-0.15 ; P<0.05$ \\
\hline
\end{tabular}




\section{SEARCH PLAN AND RESULTS}

\section{Inclusion and exclusion criteria}

This table provides the inclusion and exclusion criteria for the systematic review question(s): What is the relationship between timing of introduction of complementary foods and beverages and bone health? The inclusion and exclusion criteria are a set of characteristics to determine which studies will be included or excluded in the systematic review.

Table 2. Inclusion and exclusion criteria

\begin{tabular}{|c|c|c|}
\hline Category & Inclusion Criteria & Exclusion Criteria \\
\hline \multirow[t]{6}{*}{ Study design } & Randomized controlled trials & Cross-sectional studies \\
\hline & Non-randomized controlled trials & Uncontrolled studies \\
\hline & Prospective cohort studies & Pre/post studies without a control \\
\hline & Retrospective cohort studies & Narrative reviews \\
\hline & Case-control studies & Systematic reviews \\
\hline & Pre/post studies with a control & Meta-analyses \\
\hline $\begin{array}{l}\text { Independent } \\
\text { variable } \\
\text { (intervention or } \\
\text { exposure) }\end{array}$ & $\begin{array}{l}\text { Timing of introduction to complementary } \\
\text { foods and beverages (CFB) (i.e., foods } \\
\text { and beverages (liquids, semisolids, and } \\
\text { solids) other than human milk or infant } \\
\text { formula provided to an infant or young } \\
\text { child to provide nutrients and energy) }\end{array}$ & $\begin{array}{l}\text { Consumption of fluid cow's milk } \\
\text { before } 12 \text { months of age }\end{array}$ \\
\hline Comparator & Different timing of introduction of CFB & \\
\hline \multirow[t]{3}{*}{$\begin{array}{l}\text { Dependent } \\
\text { variables } \\
\text { (outcomes) }\end{array}$} & $\begin{array}{l}\text { Bone mass, including bone mineral } \\
\text { density and bone mineral content }\end{array}$ & \\
\hline & Biomarkers of bone metabolism & \\
\hline & $\begin{array}{l}\text { Incidence and prevalence of osteoporosis, } \\
\text { osteopenia, rickets, and/or fracture }\end{array}$ & \\
\hline Date range & January 1980 - July 2016 & \\
\hline Language & Studies published in English & $\begin{array}{l}\text { Studies published in languages other } \\
\text { than English }\end{array}$ \\
\hline $\begin{array}{l}\text { Publication } \\
\text { status }\end{array}$ & $\begin{array}{l}\text { Studies published in peer-reviewed } \\
\text { journals }\end{array}$ & $\begin{array}{l}\text { Grey literature, including unpublished } \\
\text { data, manuscripts, reports, abstracts, } \\
\text { conference proceedings }\end{array}$ \\
\hline Country $2,3,4$ & $\begin{array}{l}\text { Studies conducted in Very High or High } \\
\text { Human Development Countries }\end{array}$ & $\begin{array}{l}\text { Studies conducted in Medium or Low } \\
\text { Human Development Countries }\end{array}$ \\
\hline
\end{tabular}




\begin{tabular}{lll}
\hline \hline Category & Inclusion Criteria & Exclusion Criteria
\end{tabular}

Study Human subjects
participants

Males

Females

\begin{abstract}
Age of study Age at intervention or exposure: Infants participants
\end{abstract}

\section{Health status of study participants}

\section{Source of foods and beverages}

Hospitalized patients, not including

birth and immediate post-partum

hospitalization of healthy babies
Age at outcome: Infants (0-12mo); Toddlers (12-24mo); Child (2-5 years $(\mathrm{y}))$; Child (6-12y); Adolescents (13-18y)

Studies done in generally healthy populations

Studies done in populations where infants were full term ( $\geq 37 \mathrm{wk}$ gestational age)

Studies done in populations with elevated chronic disease risk, or that enroll some participants with a disease or with the health outcome of interest
Age at intervention or exposure: Child (2-5 years $(\mathrm{y}))$; Child (6-12y); Adolescents (13-18y); Adults (19y and older); Older adults (65 to $79 y$ ); Older adults $(80+y)$

Age at outcome: Adults (19y and older); Older adults (65 to 79y); Older adults (80+y)

Studies that exclusively enroll subjects with a disease or with the health outcome of interest

Studies done in hospitalized or malnourished subjects

Studies of exclusively pre-term babies (gestational age $<37 \mathrm{wk}$ ) or babies that are small for gestational age $(<2500 \mathrm{~g})$

Studies of subjects with infectious diseases (e.g. HIVIAIDS) (or with mothers diagnosed with an infectious disease)

Whole food sources Human milk

Fortified foods/beverages

Infant formulas (e.g., milk-based, soy, partially-hydrolyzed, extensivehydrolyzed, amino acid-based)

Enriched foods/beverages
Vitamin and mineral supplements (e.g., iron drops)

\footnotetext{
${ }^{1}$ Risk of bias was assessed using the Nutrition Evidence Library Bias Assessment Tool. Available at nesr.usda.gov.

2 United Nations Development Programme. Human Development Report 2014: Reducing Vulnerabilities and Building Resilience. Available from: http://hdr.undp.org/en/content/human-development-report-2014.

${ }^{3}$ Medium Development Countries were originally included, but due to concerns about generalizability to the U.S. of study participants (i.e., baseline health status) and CFB typically consumed, a decision was made to exclude "Medium" countries in October 2017.
} 
${ }^{4}$ When a country was not included in the Human Development Report 2014, country classification from the World Bank was used instead (The World Bank. Internet: https://datahelpdesk.worldbank.org/knowledgebase/articles/906519-worldbank-country-and-lending-groups (accessed March 27, 2018)

\section{Search terms and electronic databases used}

PubMed, US National Library of Medicine (1966 to 19 July 2016):

Date(s) Searched: 7/19/2016

Search Terms:

Complementary OR supplementary OR wean* OR transition* OR introduc* OR "Infant Nutritional Physiological Phenomena"[Mesh:noexp] OR weaning[mesh] OR ((bottle*) NOT (milk OR formula))

AND (feeding* OR food OR beverage*[tiab] OR beverages[mh] OR eating OR

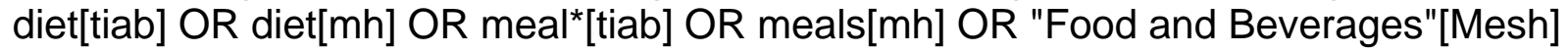
OR diets[tiab] OR cereal*[tiab] OR "Edible Grain"[Mesh] OR bread*[tiab] OR whole grain* OR juice*[tiab] OR milk[tiab] OR "Milk"[Mesh] OR dairy[tiab] OR "Dairy Products"[Mesh] OR meat[tiab] OR cheese[tiab] OR yogurt[tiab] OR yoghurt*[tiab] OR fruit*[tiab] OR "Fruit"[Mesh] OR vegetable*[tiab] OR "Vegetables"[Mesh] OR egg*[tiab] OR "Eggs"[Mesh] OR nut[tiab] OR nuts[tiab] OR peas[tiab] OR beans[tiab] OR legume*[tiab] OR snack*[tiab] OR bread[mh] OR honey[mh] OR vegetable*[tiab] OR "Vegetables"[Mesh] OR egg*[tiab] OR "Eggs"[Mesh:noexp] OR "egg white"[mh] OR "egg yolk"[mh] OR snack*[tiab] OR candy[mh] OR "Fast Foods"[Mesh] OR meat[mh] OR molasses[mh] OR nuts[mh] OR "Raw Foods"[Mesh] OR seeds[mh])

OR "infant food"[mesh]

OR infant feed*

OR

(breast feeding[mh] OR breastfeeding[tiab] OR breast feeding*[tiab] OR breastfeeding*[tiab] OR breastfed[tiab] OR breast-fed[tiab] OR breast-feed OR breast-feeds)

OR

(Bottle feeding[mh] OR bottle feeding*[tiab]s OR bottle feeding OR bottle-feeding*[tiab] OR bottle-feedings OR bottle-fed[tiab] OR "bottle fed"[tiab])

NOT (editorial[ptyp] OR comment[ptyp] OR news[ptyp] OR letter[ptyp] OR review[ptyp] OR systematic[sb])

OR ((Solid food*) OR solids));

AND

Growth[mh:noexp] OR "Child Development"[Mesh] OR "Growth Charts"[Mesh] OR "growth and development" [Subheading] OR "growth and development"[tiab] OR "Growth and Development"[Mesh:noexp] OR "Growth"[tiab] OR development*[tiab] OR "Child Development"[Mesh] OR child develop*[tiab] OR tooth[mh] OR tooth[tiab] OR 
teeth[tiab] OR movement[mh] OR "Overnutrition"[Mesh] OR under-nutrition[tiab] OR undernutrition[tiab] OR "developmental delay"[tiab] OR "Motor Skills"[Mesh] OR "Nonverbal Communication"[Mesh]

Standing[tiab] OR sitting[tiab] OR walking[tiab] OR crawling[tiab] OR "Motor Skills"[Mesh] OR Ages and Stages Questionnaire* OR ASQ[tiab]

OR Cognitive[tiab] OR cognition[mh] OR cognition OR learning OR "Learning Disorders"[Mesh] OR "Intellectual Disability"[Mesh] OR intelligence[tiab] OR intelligence[mh] OR "Achievement"[Mesh] OR "Aptitude"[Mesh] OR "Executive Function"[Mesh] OR memory OR inhibitory control*[tiab] OR "problem solving"[tiab] OR"Social-emotional development"[tiab] OR "Neurological development"[tiab] OR "mental development"[tiab] OR

"Motor development"[tiab] OR anxiety[tiab] OR anxiety[mh:noexp] OR "Anxiety, Separation"[Mesh] OR depression[tiab] OR depression[mh] OR "Depression, Postpartum"[Mesh] OR "Depressive Disorder"[Mesh] OR "Visual Acuity"[Mesh] OR "Auditory Perception"[Mesh] OR "Psychological Tests"[Mesh]

OR

("Bone Density"[Mesh] OR "bone density"[tiab] OR "Bone Development"[Mesh] OR "Bone Development"[tiab] OR "Fractures, Bone"[Mesh] OR "Bone Diseases"[Mesh] OR osteoporosis[tiab] OR (bone[tiab] AND fracture*[tiab]) OR "Rickets"[Mesh] OR ricket*[tiab] OR bone mineral*[tiab] OR "bone mass"[tiab] OR bone health*[tiab] OR "Bone Demineralization, Pathologic"[Mesh] OR bone demineral*[tiab])

OR

("body size"[tiab] OR body size[mh] OR obesity[tiab] OR obese[tiab] OR overweight[mh] OR obesity[mh] OR overweight [tiab] OR adipos*[tiab] OR adiposity[mh] OR "body composition"[mh] OR body fat distribution[mh] OR "body fat"[tiab] OR "body weight"[tiab] OR body weight[mh] OR birth weight*[tiab] OR weight gain[mh] OR weight loss[mh] OR "body-weight"[tiab] OR "weight gain"[tiab] OR weightgain[tiab] OR weight loss[tiab] OR weight-loss[tiab] OR "Body Weights and Measures"[mh] OR weight[ti] OR "Anthropometry"[Mesh:noexp] OR body mass index[mh] OR "body mass index"[tiab] OR BMI[tiab] OR "weight status"[tiab] OR "adipose tissue"[mh] OR "healthy weight"[tiab] OR waist circumference[mh] OR "body mass"[ti] OR "fat mass"[tiab] OR body weight changes[mh] OR "waist circumference"[tiab] OR ideal body weight[mh] OR waist-hip ratio[mh] OR Waist Hip*[tiab] OR body height*[tiab] OR Crown-Rump Length*[tiab] OR head circumference*[tiab] OR arm circumference ${ }^{*}[$ tiab] OR thigh circumference* OR limb circumference* OR fat free mass*[tiab] OR skinfold[tiab] OR skin fold*[tiab])

AND

infant* OR baby OR babies OR toddler* OR newborn*[tiab] OR "Child, Preschool"[Mesh] OR preschool*[tiab] OR pre-school*[tiab] OR "early childhood"[tiab] OR "early years"[tiab] OR pre-k[tiab] OR pre-primary[tiab] OR under five*[ti] OR young child*[ti] OR "head start"[tiab] OR prekindergarten[tiab] OR pre-kindergarten[tiab] OR 
weanling*

OR limit to child, preschool

for child 0-18 all develop outcomes

for all; body wgt/comp/bone

NOT

nutritional status[mh] OR nutritional status*[tiab] OR Nutrition Status*[tiab] OR Iron[mh] OR iron[tiab] OR "Anemia"[Mesh] OR "Anemia"[tiab] OR iron deficien*[tiab] OR ferritin*[tiab] OR ferrous[tiab] OR "Transferrin"[Mesh] OR "Transferrin"[tiab] OR zinc OR "Vitamin D"[Mesh] OR "Vitamin D"[tiab] OR "Vitamin D Deficiency"[Mesh] OR "Vitamin B 12"[Mesh] OR "Vitamin B 12"[tiab] OR "Vitamin B12"[tiab] OR "Vitamin B 12 Deficiency"[Mesh] OR Cobamide*[tiab] OR Cobalamin*[tiab] OR Cyanocobalamin[tiab] OR Folate[tiab] OR "Folic Acid"[Mesh] OR folacin[tiab] OR vitamin b9*[tiab] OR Fatty acid*[tiab] OR "Fatty Acids"[Mesh:noexp] OR fatty acid*[tiab] OR "Fatty Acids, Unsaturated"[Mesh:noexp] OR Arachidonic acid*[tiab] OR linolenic acid*[tiab] OR linoleic acid*[tiab] OR Docosahexaenoic Acid*[tiab] OR Eicosapentaenoic Acid*[tiab] OR gamma-Linolenic Acid*[tiab] OR "Arachidonic Acids"[Mesh] OR "Fatty Acids, Essential"[Mesh] OR "Fatty Acids, Omega-3"[Mesh] OR "Fatty Acids, Omega-6"[Mesh] OR alpha-Linolenic Acid*[tiab] OR "Fatty Acids, Essential"[Mesh] OR "Linolenic Acids"[Mesh] OR "Trans Fatty Acids"[Mesh] OR "Fatty Acids, Monounsaturated"[Mesh]

for nonmedline[sb]: NOT animals by: NOT (sheep[ti] OR lamb[ti] OR lambs[ti] OR calving[ti] OR calves[ti] OR mice[ti] OR mouse[ti] OR pigs[ti] OR cows[ti] OR piglets[ti] OR cow[ti] OR piglet[ti] OR monkey[ti] OR rats[ti] OR rat[ti] OR animal*[ti])

\section{Embase, Elsevier (1947 to 1 August 2016):}

Date(s) Searched: 8/1/16

Search Terms:

(Complementary OR supplementa* OR wean* OR transition* OR introduc* OR family) NEAR/3 (feed* OR food* OR beverage* OR eating OR diet)

OR

(Complementary OR transition* OR introduct* OR wean*) AND (food/exp OR 'baby food'/exp OR 'cereal'/exp OR 'dairy product'/exp OR 'egg'/exp OR 'fruit'/exp OR 'meat'/exp OR 'sea food'/exp OR 'milk'/exp OR fish/exp OR 'poultry'/exp OR 'beverage'/exp OR 'vegetable'/exp OR nut/exp OR pea/exp OR meal/exp)

OR

(Complementary OR supplementa* OR wean* OR transition* OR introduc*) NEAR/5 ('whole grain' OR 'whole grains' OR dairy OR egg OR eggs OR meat OR poultry OR seafood OR fruit* OR milk OR fish* OR poultry OR beverage* OR vegetables* OR pea OR peas OR nut OR nuts OR cereal OR bread* OR yog*urt* OR cheese* OR juice* OR rice OR soup OR legume* OR snack* OR meal*) (for Embase)

OR 'baby food'/de OR (solid NEAR/2 food*):ab,ti 
AND

(infant*:ti,ab OR infant/exp) OR (baby OR babies OR toddler* OR newborn* OR nurser*):ti,ab OR 'newborn'/exp OR 'newborn care'/exp OR preschool*:ti,ab OR preschool:ti,ab OR 'preschool child'/exp OR 'infancy'/exp OR "early childhood":ti,ab OR "early years" OR pre-k:ti,ab OR 'nursery'/exp OR 'nursery school'/exp OR prekindergarten:ti,ab OR pre-kindergarten:ti,ab OR weanling*

AND ([in process]/lim OR [article]/lim OR [article in press]/lim) AND ([embase]/lim NOT [medline]/lim)

AND

Limit to humans:

AND

'executive function'/exp OR 'executive function':ti,ab OR 'learning'/exp OR 'intelligence'/exp OR 'mental development'/exp OR 'mental development':ti,ab OR intelligence:ti,ab OR cogniti*:ti,ab OR 'cognition'/exp OR 'cognition assessment'/exp OR aptitude:ti,ab OR 'memory'/exp OR memory:ti,ab OR 'anxiety'/exp OR 'anxiety':ti,ab OR 'depression'/exp OR depressi*:ti,ab OR 'visual acuity'/exp OR visual:ti OR 'hearing'/exp OR hearing:ti,ab OR auditory:ti,ab OR 'postnatal development'/exp OR 'postnatal development':ti,ab OR 'overnutrition'/exp OR 'overnutrition':ti,ab OR undernutrition:ti,ab OR "developmental delay":ti,ab OR 'nonverbal communication'/exp

OR

('metabolic bone disease'/exp OR osteoporosis:ti,ab OR (bone NEAR/2 (disease* OR fracture* OR injur* OR health* OR density OR mineralize* OR demineraliz*)):ti,ab OR ricket*:ti,ab OR 'bone injury'/exp OR 'bone density'/exp)

AND

'body size'/de OR 'body size':ti,ab OR 'obesity'/exp OR overweight:ab,ti OR 'macrosomia'/exp OR obese:ab,ti OR obesity:ab,ti OR 'weight gain':ab,ti OR adiposity:ab,ti OR adipose:ab,ti OR 'body weight'/exp OR 'body weight':ti,ab OR 'weight gain'/de OR 'body composition'/exp OR 'body composition':ti,ab OR 'body fat':ab,ti OR 'anthropometry'/de OR 'body mass'/de OR bmi:ab,ti OR 'body mass':ab,ti OR weight:ab,ti OR (waist NEXT/1 hip NEXT/1 ratio*) OR 'body fat'/de OR 'adipose tissue'/exp OR skinfold OR 'skin fold':ti,ab OR 'fat mass':ti,ab OR 'fat mass'/exp OR 'anthropometric parameters'/exp OR circumference OR length OR height

OR

'body growth'/exp 'body growth':ti,ab OR 'growth rate and growth regulation'/exp OR 'postnatal growth'/exp OR 'human development'/exp OR 'Bayley Scales of Infant Development'/exp OR 'cognition assessment'/exp OR 'mental function assessment'/de 
Cochrane Central Register of Controlled Trials, John Wiley \& Sons in the Cochrane Library (searched 9 August 2016):

Date(s) Searched: 8/9/16

Search Terms:

(feed* OR food* OR beverage*OR diet* OR 'whole grain' OR 'whole grains' OR dairy OR egg OR meat OR poultry OR seafood OR fruit* OR milk OR fish* OR poultry OR vegetables* OR pea OR beans OR legume* OR nut OR cereal OR beverage* OR bread* OR seafood OR yog*urt* OR cheese OR juice OR snack OR yogurt OR yoghurt OR nut OR nuts OR honey OR meal OR meals) NEAR/3 (Complementary OR supplementa* OR wean* OR transition* OR introduct* OR family)

OR

[mh ^"Infant Nutritional Physiological Phenomena"] OR [mh weaning] OR ((bottle*) NOT (milk OR formula))

AND ([mh beverages] OR [mh eating] OR [mh diet] OR [mh meals] OR [mh "Food and Beverages"] OR [mh "Edible Grain"] OR [mh "Milk"] OR dairy[:ti,ab OR [mh "Dairy Products"] OR [mh "Fruit"] OR [mh "Vegetables"] OR [mh "Eggs"] OR [mh bread] OR [mh honey] OR [mh "Vegetables"] OR [mh ^"Eggs"] OR [mh "egg white"] OR [mh "egg yolk"] OR [mh candy] OR [mh "Fast Foods"] OR [mh meat] OR [mh molasses] OR [mh nuts] OR [mh "Raw Foods"] OR [mh seeds])

OR

((Infant* OR baby* OR babies) NEAR/2 food*):ti,ab OR [mh "infant food"]

AND

[mh ^Growth] OR [mh "Child Development"] OR [mh "Growth Charts"] OR "growth and development" OR [mh^" "Growth and Development"] OR [mh "Child Development"] OR (child NEAR/1 develop*):ti,ab OR [mh tooth] OR tooth:ti,ab OR teeth:ti,ab OR [mh movement] OR [mh "Overnutrition"] OR "under-nutrition:ti,ab OR undernutrition:ti,ab OR [mh "Motor Skills"] OR [mh "Nonverbal Communication"]

OR

'body growth':ti,ab OR 'growth rate and growth regulation' OR 'postnatal growth':ti,ab OR 'human development':ti,ab OR 'Bayley Scales of Infant Development'

OR Standing:ti,ab OR sitting:ti,ab OR walking:ti,ab OR crawling:ti,ab OR "Ages and Stages Questionnaire" OR ASQ:ti,ab

OR [mh cognition] OR [mh learning] OR [mh "Learning Disorders"] OR [mh "Intellectual Disability"] OR intelligence:ti,ab OR [mh intelligence] OR [mh "Achievement"] OR [mh "Aptitude"] OR [mh "Executive Function"] OR (inhibitory NEAR/1 control*):ti,ab OR "problem solving":ti, ab OR "Social-emotional development":ti,ab OR "Neurological development":ti,ab OR "mental development":ti, ab OR "Motor development"ti,ab OR [mh ^anxiety] OR [mh "Anxiety, Separation"] OR [mh depression] OR [mh "Depression, Postpartum"] OR [mh "Depressive Disorder"] OR [mh "Visual Acuity"] OR [mh "Auditory Perception"] OR [mh "Psychological Tests"] 
OR Stunt*:ti,ab OR wasting:ti,ab

OR

cogniti*:ti,ab OR aptitude:ti,ab OR memory:ti,ab OR [mh memory] OR 'anxiety':ti,ab OR depressi*:ti,ab OR visual:ti,ab OR vision:ti,ab OR hearing:ti,ab OR auditory:ti,ab OR 'postnatal development':ti,ab OR 'overnutrition':ti,ab OR "developmental delay":ti,ab OR 'nonverbal communication'

OR

[mh "Bone Density"] OR [mh "Bone Development"] OR [mh "Fractures, Bone"] OR [mh "Bone Diseases"] OR [mh "Rickets"] OR [mh "Bone Demineralization, Pathologic"] OR osteoporosis:ti,ab OR (bone NEAR/2 (disease* OR fracture* OR injur* OR health* OR density OR mineral* OR demineral* OR develop* OR mass)):ti,ab OR ricket*:ti,ab

OR 'body size':ti,ab OR overweight:ab,ti OR 'macrosomia':ti,ab OR obese:ab,ti OR obesity:ab,ti OR adipos*:ab,ti OR 'body weight':ti,ab OR 'weight gain':ti,ab OR 'body composition':ti,ab OR 'body fat':ab,ti OR 'anthropometr':ti,ab OR bmi:ab,ti OR 'body mass':ab,ti OR (waist NEXT/1 hip NEXT/1 ratio*) OR 'body fat':ti,ab OR 'adipose tissue':ti,ab OR skinfold:ti,ab OR 'skin fold':ti,ab OR 'fat mass':ti,ab OR circumference:ti,ab OR length:ti,ab OR height:ti,ab

([mh "body size"] OR [mh overweight] OR [mh obesity] OR [mh adiposity] OR [mh "body composition"] OR [mh "body fat distribution"] OR [mh "body weight"] OR [mh "weight gain"] OR [mh "weight loss"] OR "weight gain":ti,ab OR "weight loss":ti,ab OR "weight-loss":ti,ab OR [mh "Body Weights and Measures"] OR weight:ti OR [mh ^"Anthropometry"] OR [mh "body mass index"] OR "weight status":ti,ab OR [mh "adipose tissue"] OR "healthy weight":ti,ab OR [mh "waist circumference"] OR [mh "body weight changes"] OR [mh "ideal body weight"] OR [mh "waist-hip ratio"] OR "Waist Hip":ti,ab OR "waist-hip":ti,ab OR “Crown-Rump":ti,ab OR "fat free mass":ti,ab)

NOT (pubmed OR embase)

\section{CINAHL Plus with Full Text, EBSCO (Cumulative Index to Nursing and Allied Health Literature; 1937 to 22 August 2016):}

Date(s) Searched: 8/22/2016

Search Terms:

(MH "Food and Beverages+") OR (MH "Food") OR (MH "Diet") OR (MH "Eating") OR (MH "Eating Behavior") OR (MH "Taste") OR (MH "Taste Buds") OR (MH "Cereals") OR (MH "Dairy Products") OR (MH "Yogurt") OR (MH "Cheese") OR (MH "Milk") OR (MH "Eggs") OR (MH "Fruit") OR (MH "Fruit Juices") OR (MH "Meat") OR (MH "Seafood") OR (MH "Fish") OR (MH "Poultry") OR (MH "Vegetables") OR (MH "Nuts") OR (MH "Legumes") OR (MH "Bread") AND (Complementary OR supplementa* OR wean* OR transition* OR introduc*) 
OR

('whole grain' OR 'whole grains' OR dairy OR egg OR eggs OR meat OR poultry OR seafood OR fruit* OR milk OR fish* OR poultry OR vegetables* OR pea OR peas OR nut OR nuts OR cereal OR beverage* OR bread* OR seafood OR yog*urt* OR cheese* OR juice*) N5 (Complementary OR supplementa* OR wean* OR transition* OR introduc* OR family)

OR (Infant* OR baby OR babies) N2 food*

NOT

(MH "Nutritional Status") OR "nutritional status" OR (MH "Nutritional Requirements") OR (MH "Vitamin D") OR (MH "Vitamin D Deficiency") OR (MH "Vitamin B12 Deficiency") OR (MH "Anemia") OR "anemia" OR (MH "Anemia, Iron Deficiency") OR (MH "Iron") OR (MH "Zinc") OR (MH "Vitamin B12") OR (MH "Vitamin B12 Deficiency") OR (MH "Folic Acid") OR (MH "Niacin") OR (MH "Folic Acid Deficiency") OR "folate" OR "folacin" OR cyanocobalamin* OR cobalamin* OR cobamamide* OR (MH "Fatty Acids") OR "fatty acids" OR (MH "Fatty Acids, Omega-6") OR (MH "Fatty Acids, Omega-3") OR (MH "Fatty Acids, Unsaturated") OR (MH "Trans Fatty Acids") OR (MH "Fatty Acids, Monounsaturated") OR (MH "Fatty Acids, Saturated") OR (MH "Fatty Acids, Essential") OR (MH "Arachidonic Acids") OR (MH "Docosahexaenoic Acids") OR (MH "Linolenic Acids") OR (MH "Linoleic Acids")

AND osteoporosis OR (bone n2 (disease* OR fracture* OR injur* OR health* OR density OR mineralize* OR demineraliz*)) OR ricket* OR (MH "Osteoporosis") OR (MH "Bone Density") OR

(MH "Bone Diseases+") OR (MH "Bone Diseases, Developmental+") OR (MH "Rickets+")

OR

(MH "Executive Function") OR (MH "Learning+") OR (MH "Intelligence+") OR "intelligence" OR (MH "Intelligence Tests") OR (MH "Cognition+") OR "cognition" OR "mental development" OR (MH "Aptitude") OR "aptitude" OR (MH "Aptitude Tests+") OR (MH "Memory+") OR "memory" OR (MH "Anxiety+") OR "anxiety" OR (MH "Depression+") OR "depression" OR (MH "Visual Acuity") OR (MH "Visual Perception+") OR (MH "Hearing+") OR "auditory" OR "overnutrition" OR "undernutrition" OR (MH "Nonverbal Communication+") OR "postnatal development" OR OR "developmental delay"

OR

(MH "Anthropometry+") OR (MH "Body Weights and Measures+") OR (MH "Body Weight+") OR

(MH "Bone Development+") OR (MH "Growth+") OR (MH "Human Development+") OR "bayley scales" OR "mental function" OR (MH "Body Size") OR (MH "Obesity+") OR "overweight" OR "macrosomia" OR (MH "Weight Gain+") OR (MH "Waist-Hip Ratio") OR (MH "Body Composition+") OR (MH "Adipose Tissue+") OR (MH "Abdominal Fat") 
OR (MH "Fat Free Mass") OR (MH "Body Mass Index") OR (MH "Skinfold Thickness") OR (MH "Head Circumference") OR (MH "Arm Circumference") OR (MH "Waist Circumference") OR (MH "Growth and Development (Omaha)") OR (MH "Body Height") OR (MH "Crown-Rump Length") OR (MH "Leg Length Inequality") OR (MH "Mean Length of Utterance")

\section{Figure 2: Flow chart of literature search and screening results}

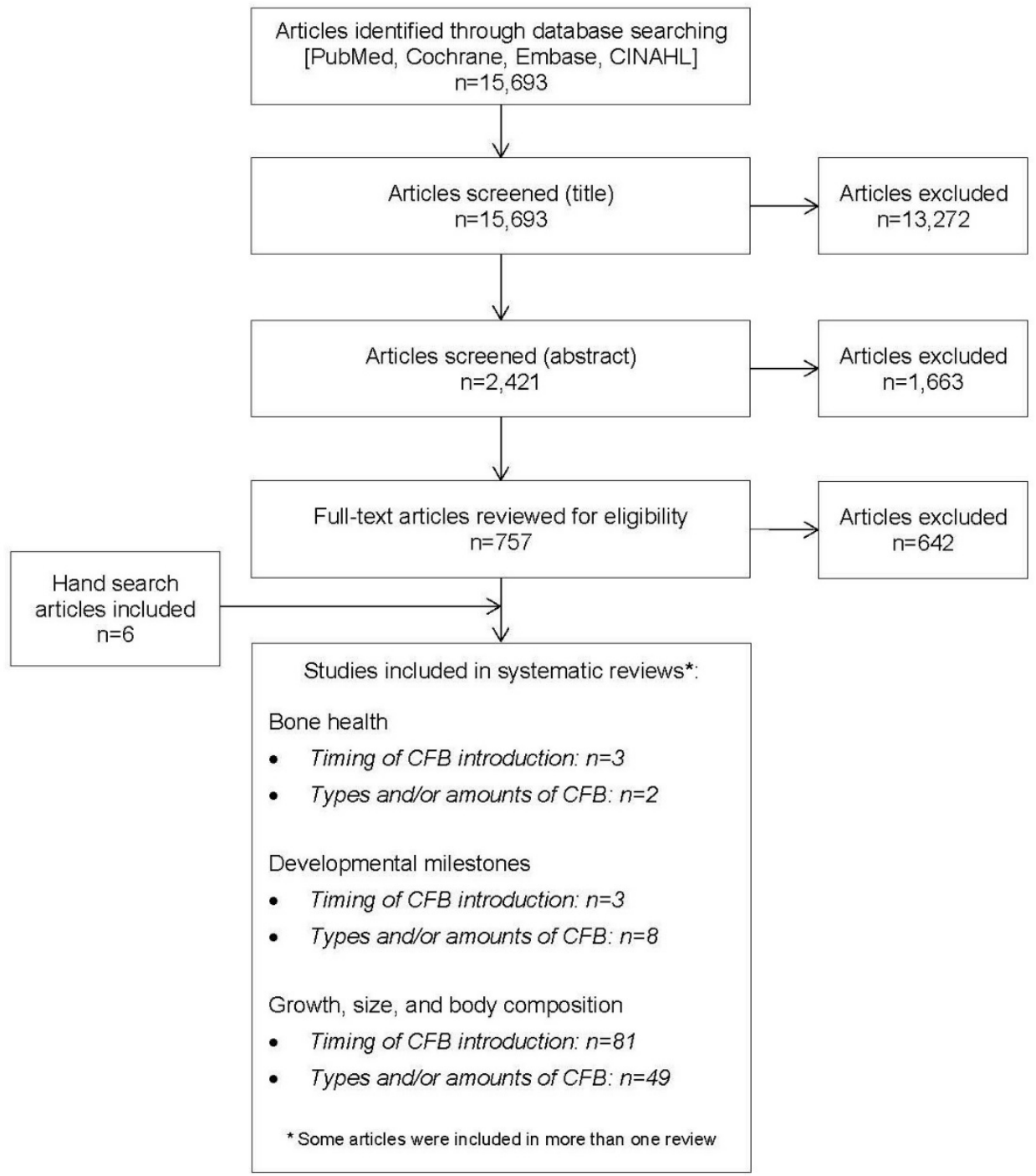

This flow chart illustrates the literature search results for articles examining the relationship between complementary feeding and bone health. The results of an electronic database search were screened independently by two NESR analysts in a dual, step-wise manner by reviewing titles, abstracts, and full text articles to determine which articles met the criteria for inclusion. A manual search was done to ascertain articles not identified through the electronic database search. The systematic review on timing of introduction of CFB included three articles, and the systematic review on types and amounts of CFB consumed included two articles. The literature search was conducted for multiple systematic reviews that addressed complementary feeding and 
various health outcomes; the systematic reviews on developmental milestones and growth, size, and body composition are described in separate reports. 


\section{Excluded articles}

The table below lists the excluded articles with at least one reason for exclusion, but may not reflect all possible reasons.

Table 3. Excluded articles

\begin{tabular}{|c|c|c|}
\hline & Citation & Rationale \\
\hline 1 & Complementary feeding in the WHO Multicentre Growth Reference Study. Acta Paediatr Suppl.2006;450:27-37. & DV \\
\hline 2 & $\begin{array}{l}\text { Weaning and the weaning diet. Report of the Working Group on the Weaning Diet of the Committee on Medical Aspects of } \\
\text { Food Policy. Rep Health Soc Subj (Lond).1994;45:1-113. }\end{array}$ & Design \\
\hline 3 & $\begin{array}{l}\text { Aarts, C.,Kylberg, E.,Hofvander, Y.,Gebre-Medhin, M. Growth under privileged conditions of healthy Swedish infants } \\
\text { exclusively breastfed from birth to 4-6 months: a longitudinal prospective study based on daily records of feeding. Acta } \\
\text { Paediatr.2003;92:145-51. }\end{array}$ & IV \\
\hline 4 & $\begin{array}{l}\text { Abarin, T.,Yan Wu, Y.,Warrington, N.,Lye, S.,Pennell, C.,Briollais, L. The impact of breastfeeding on FTO-related BMI } \\
\text { growth trajectories: an application to the Raine pregnancy cohort study. Int J Epidemiol.2012;41:1650-60. }\end{array}$ & IV \\
\hline 5 & $\begin{array}{l}\text { Abou Samra, H.,Stevens, D.,Binkley, T.,Specker, B. Determinants of bone mass and size in 7-year-old former term, late- } \\
\text { preterm, and preterm boys. Osteoporos Int.2009;20:1903-10. }\end{array}$ & Design, IV \\
\hline 6 & $\begin{array}{l}\text { Aboud, F. E.,Akhter, S. A cluster-randomized evaluation of a responsive stimulation and feeding intervention in } \\
\text { bangladesh. Pediatrics.2011;127:e1191-7. }\end{array}$ & IV \\
\hline 7 & $\begin{array}{l}\text { Aboud, F. E.,Shafique, S.,Akhter, S. A responsive feeding intervention increases children's self-feeding and maternal } \\
\text { responsiveness but not weight gain. J Nutr.2009;139:1738-43. }\end{array}$ & IV \\
\hline 8 & $\begin{array}{l}\text { Adu-Afarwuah, S.,Lartey, A.,Brown, K. H.,Zlotkin, S.,Briend, A.,Dewey, K. G. Randomized comparison of } 3 \text { types of } \\
\text { micronutrient supplements for home fortification of complementary foods in Ghana: effects on growth and motor } \\
\text { development. Am J Clin Nutr.2007;86:412-20. }\end{array}$ & IV \\
\hline 9 & $\begin{array}{l}\text { Agarwal, K. N.,Agarwal, D. K.,Gupta, A.,Bansal, A. K. Relationship of exclusive breast feeding for } 6 \text { mo to linear growth up } \\
\text { to } 18 \text { mo of age. Indian J Pediatr.2013;80:11-5. }\end{array}$ & Country \\
\hline 10 & $\begin{array}{l}\text { Aggarwal, A.,Arora, S.,Patwari, A. K. Breastfeeding among urban women of low-socioeconomic status: factors influencing } \\
\text { introduction of supplemental feeds before four months of age. Indian Pediatr.1998;35:269-73. }\end{array}$ & $\begin{array}{l}\text { Design, IV, } \\
\text { DV }\end{array}$ \\
\hline 11 & $\begin{array}{l}\text { Agostoni, C.,Fiocchi, A.,Riva, E.,Terracciano, L.,Sarratud, T.,Martelli, A.,Lodi, F.,D'Auria, E.,Zuccotti, G.,Giovannini, M. } \\
\text { Growth of infants with IgE-mediated cow's milk allergy fed different formulas in the complementary feeding period. Pediatr } \\
\text { Allergy Immunol.2007;18:599-606. }\end{array}$ & IV \\
\hline 12 & $\begin{array}{l}\text { Agostoni, C.,Grandi, F.,Gianni, M. L.,Silano, M.,Torcoletti, M.,Giovannini, M.,Riva, E. Growth patterns of breast fed and } \\
\text { formula fed infants in the first } 12 \text { months of life: an Italian study. Arch Dis Child.1999;81:395-9. }\end{array}$ & IV \\
\hline
\end{tabular}


13 Agostoni, C.,Grandi, F.,Scaglioni, S., Gianni, M. L., Torcoletti, M.,Radaelli, G.,Fiocchi, A., Riva, E. Growth pattern of

breastfed and nonbreastfed infants with atopic dermatitis in the first year of life. Pediatrics.2000;106:E73.

14 Agostoni,C.,Marangoni,F.,Lammardo,A. M.,Giovannini,M.,Riva,E.,Galli,C. Breastfeeding duration, milk fat composition and developmental indices at 1 year of life among breastfed infants. Prostaglandins Leukot Essent Fatty Acids.2001;64:105-9.

15 Agostoni,C.,Zuccotti,G. V.,Radaelli,G.,Besana,R.,Podesta,A.,Sterpa,A.,Rottoli,A.,Riva,E.,Giovannini,M. Docosahexaenoic acid supplementation and time at achievement of gross motor milestones in healthy infants: a randomized, prospective, double-blind, placebo-controlled trial. Am J Clin Nutr.2009;89:64-70.

16 Allen, L.,Shrimpton, R. The International Research on Infant Supplementation study: implications for programs and further research. J Nutr.2005;135:666s-669s.

17 Alm,B.,Aberg,N.,Erdes,L.,Mollborg,P.,Pettersson,R.,Norvenius,S. G.,Goksor,E.,Wennergren,G. Early introduction of fish decreases the risk of eczema in infants. Arch Dis Child.2009;94:11-5.

18 Almqvist,C.,Garden,F.,Xuan,W.,Mihrshahi,S.,Leeder,S. R.,Oddy,W.,Webb,K.,Marks,G. B. Omega-3 and omega-6 fatty acid exposure from early life does not affect atopy and asthma at age 5 years. J Allergy Clin Immunol.2007;119:1438-44.

19 Alvarez-Uria, G.,Midde, M.,Pakam, R.,Bachu, L.,Naik, P. K. Effect of Formula Feeding and Breastfeeding on Child Growth Infant Mortality, and HIV Transmission in Children Born to HIV-Infected Pregnant Women Who Received Triple Antiretroviral Therapy in a Resource-Limited Setting: Data from an HIV Cohort Study in India. ISRN Pediatr.2012;2012:763591.

20 Andersen, L. B.,Molgaard, C.,Michaelsen, K. F.,Carlsen, E. M.,Bro, R.,Pipper, C. B. Indicators of dietary patterns in Danish infants at 9 months of age. Food Nutr Res.2015;59:27665.

21 Andersen,A. D.,Michaelsen,K. F.,Hellgren,L. I.,Trolle,E.,Lauritzen,L. A randomized controlled intervention with fish oil versus sunflower oil from 9 to 18 months of age: exploring changes in growth and skinfold thicknesses. Pediatr Res.2011;70:368-74.

22 Andersen,L. B.,Pipper,C. B.,Trolle,E.,Bro,R.,Larnkjaer,A.,Carlsen,E. M.,Molgaard,C.,Michaelsen,K. F. Maternal obesity and offspring dietary patterns at 9 months of age. Eur J Clin Nutr.2015;69:668-75.

23 Anderson, G. H.,Morson-Pasut, L. A.,Bryan, H.,Cleghorn, G., Tanaka, P., Yeung, D.,Zimmerman, B. Age of introduction of cow's milk to infants. J Pediatr Gastroenterol Nutr.1985;4:692-8.

24 Anderson, V. P.,Cornwall, J.,Jack, S.,Gibson, R. S. Intakes from non-breastmilk foods for stunted toddlers living in poor urban villages of Phnom Penh, Cambodia, are inadequate. Matern Child Nutr.2008;4:146-59.

25 Andres, A.,Casey, P. H.,Cleves, M. A.,Badger, T. M. Body fat and bone mineral content of infants fed breast milk, cow's milk formula, or soy formula during the first year of life. J Pediatr.2013;163:49-54.

26 Andres, A.,Cleves, M. A.,Bellando, J. B.,Pivik, R. T.,Casey, P. H.,Badger, T. M. Developmental status of 1-year-old infants fed breast milk, cow's milk formula, or soy formula. Pediatrics.2012;129:1134-40.

27 Andrissi, L.,Mottini, G.,Sebastiani, V.,Boldrini, L., Giuliani, A. Dietary habits and growth: an urban/rural comparison in the Andean region of Apurimac, Peru. Ann Ist Super Sanita.2013;49:340-6. 


\begin{tabular}{|c|c|c|}
\hline 28 & Anfield,L. Nutrition in the first year. Midwife Health Visit Community Nurse.1985;21:161-4. & Design \\
\hline 29 & $\begin{array}{l}\text { Anzman-Frasca, S.,Liu, S.,Gates, K. M.,Paul, I. M.,Rovine, M. J.,Birch, L. L. Infants' Transitions out of a Fussing/Crying } \\
\text { State Are Modifiable and Are Related to Weight Status. Infancy.2013;18:662-686. }\end{array}$ & IV \\
\hline 30 & Armstrong, J.,Reilly, J. J. Breastfeeding and lowering the risk of childhood obesity. Lancet.2002;359:2003-4. & IV \\
\hline 31 & $\begin{array}{l}\text { Arsenault,J. E.,Havel,P. J.,Lopez de Romana,D.,Penny,M. E.,Van Loan,M. D.,Brown,K. H. Longitudinal measures of } \\
\text { circulating leptin and ghrelin concentrations are associated with the growth of young Peruvian children but are not affected } \\
\text { by zinc supplementation. Am J Clin Nutr.2007;86:1111-9. }\end{array}$ & $\begin{array}{l}\text { Health } \\
\text { status }\end{array}$ \\
\hline 32 & $\begin{array}{l}\text { Arvas, A.,Elgormus, Y.,Gur, E.,Alikasifoglu, M.,Celebi, A. Iron status in breast-fed full-term infants. Turk J } \\
\text { Pediatr.2000;42:22-6. }\end{array}$ & IV \\
\hline 33 & $\begin{array}{l}\text { Asha Bai, P. V.,Leela, M.,Subramaniam, V. R. Adequacy of breast milk for optimal growth of infants. Trop Geogr } \\
\text { Med.1980;32:158-62. }\end{array}$ & IV \\
\hline 34 & $\begin{array}{l}\text { Assuncao, M. L.,Ferreira, H. S., Coutinho, S. B.,Santos, L. M.,Horta, B. L. Protective effect of breastfeeding against } \\
\text { overweight can be detected as early as the second year of life: a study of children from one of the most socially-deprived } \\
\text { areas of Brazil. J Health Popul Nutr.2015;33:85-91. }\end{array}$ & $\begin{array}{l}\text { Design, } \\
\text { Health } \\
\text { status, IV }\end{array}$ \\
\hline 35 & $\begin{array}{l}\text { Atladottir, H.,Thorsdottir, I. Energy intake and growth of infants in Iceland-a population with high frequency of breast- } \\
\text { feeding and high birth weight. Eur J Clin Nutr.2000;54:695-701. }\end{array}$ & IV \\
\hline 36 & Auestad,N. Infant nutrition--brain development--disease in later life. An introduction. Dev Neurosci.2000;22:472-3. & Design \\
\hline 37 & $\begin{array}{l}\text { Augusto,R. A.,Souza,J. M. Effectiveness of a supplementary feeding program in child weight gain. Rev Saude } \\
\text { Publica.2010;44:793-801. }\end{array}$ & Design, IV \\
\hline 38 & $\begin{array}{l}\text { Axelsson,I. E.,Jakobsson,I.,Raiha,N. C. Formula with reduced protein content: effects on growth and protein metabolism } \\
\text { during weaning. Pediatr Res.1988;24:297-301. }\end{array}$ & IV \\
\hline 39 & $\begin{array}{l}\text { Azad, M. B.,Konya, T.,Maughan, H.,Guttman, D. S.,Field, C. J.,Chari, R. S.,Sears, M. R.,Becker, A. B.,Scott, J. } \\
\text { A.,Kozyrskyj, A. L. Gut microbiota of healthy Canadian infants: profiles by mode of delivery and infant diet at } 4 \text { months. } \\
\text { Cmaj.2013;185:385-94. }\end{array}$ & DV \\
\hline 40 & Badger, T. Effects of soy infant formula on growth and development in the first year of life. Food Nutr Bull.2013;34:252-3. & Design, IV \\
\hline 41 & $\begin{array}{l}\text { Bahamondes L,Bahamondes MV,Modesto W,Tilley IB,Magalhaes A,Pinto e Silva JL,Amaral E, Jr. Mishell DR. Effect of } \\
\text { hormonal contraceptives during breastfeeding on infant's milk ingestion and growth. Fertil Steril.2013;100:445-50. }\end{array}$ & IV \\
\hline 42 & $\begin{array}{l}\text { Bai, K. I.,Sastry, V. N.,Reddy, C. C. A comparative study of feeding pattern of infants in rural and urban areas. Indian J } \\
\text { Pediatr.1981;48:277-80. }\end{array}$ & Design, IV \\
\hline 43 & $\begin{array}{l}\text { Balaban, G.,Motta, M. E.,Silva, G. A. Early weaning and other potential risk factors for overweight among preschool } \\
\text { children. Clinics (Sao Paulo).2010;65:181-7. }\end{array}$ & IV, Age \\
\hline
\end{tabular}




\begin{tabular}{|c|c|c|}
\hline 44 & $\begin{array}{l}\text { Balogun,T. A.,Lombard,M. J.,McLachlan,M. The nutrient intake of children aged 12-36 months living in two communities in } \\
\text { the Breede Valley, Western Cape province, South Africa. South African Family Practice.2015;57:1-7 7p. }\end{array}$ & Design \\
\hline 45 & $\begin{array}{l}\text { Baranowski, T.,Bryan, G. T.,Harrison, J. A., Rassin, D. K.,Greaves, K. A.,Baranowski, J. H. Height, infant-feeding practices } \\
\text { and cardiovascular functioning among } 3 \text { or } 4 \text { year old children in three ethnic groups. J Clin Epidemiol.1992;45:513-8. }\end{array}$ & DV \\
\hline 46 & $\begin{array}{l}\text { Bartok, C. J.,Schaefer, E. W.,Beiler, J. S.,Paul, I. M. Role of body mass index and gestational weight gain in breastfeeding } \\
\text { outcomes. Breastfeed Med.2012;7:448-56. }\end{array}$ & IV, DV \\
\hline 47 & Beal, V. A. Nutrition and growth-patterns of young children. ASDC J Dent Child.1983;50:139-41. & Design \\
\hline 48 & $\begin{array}{l}\text { Begum, H. A.,Mascie-Taylor, C.,Nahar, S. The impact of food supplementation on infant weight gain in rural Bangladesh; } \\
\text { an assessment of the Bangladesh Integrated Nutritional Program (BINP). Public Health Nutr.2007;10:49-54. }\end{array}$ & IV \\
\hline 49 & $\begin{array}{l}\text { Beinner,M. A.,Velasquez-Melendez,G.,Pessoa,M. C.,Greiner,T. Iron-fortified rice is as efficacious as supplemental iron } \\
\text { drops in infants and young children. J Nutr.2010;140:49-53. }\end{array}$ & IV, DV \\
\hline 50 & $\begin{array}{l}\text { Ben,X. M.,Zhou,X. Y.,Zhao,W. H.,Yu,W. L.,Pan,W.,Zhang,W. L.,Wu,S. M.,Van Beusekom,C. M.,Schaafsma,A. Growth and } \\
\text { development of term infants fed with milk with long-chain polyunsaturated fatty acid supplementation. Chin Med J } \\
\text { (Engl).2004;117:1268-70. }\end{array}$ & IV \\
\hline 51 & $\begin{array}{l}\text { Bennett,W. E.,Jr.,Hendrix,K. S.,Thompson-Fleming,R. T.,Downs,S. M.,Carroll,A. E. Early cow's milk introduction is } \\
\text { associated with failed personal-social milestones after } 1 \text { year of age. Eur J Pediatr.2014;173:887-92. }\end{array}$ & IV \\
\hline 52 & $\begin{array}{l}\text { Bergmann, K. E.,Bergmann, R. L.,Von Kries, R.,Bohm, O.,Richter, R.,Dudenhausen, J. W.,Wahn, U. Early determinants of } \\
\text { childhood overweight and adiposity in a birth cohort study: role of breast-feeding. Int J Obes Relat Metab } \\
\text { Disord.2003;27:162-72. }\end{array}$ & IV \\
\hline 53 & $\begin{array}{l}\text { Bernal, M. J.,Periago, M. J.,Martinez, R.,Ortuno, I.,Sanchez-Solis, M.,Ros, G.,Romero, F.,Abellan, P. Effects of infant } \\
\text { cereals with different carbohydrate profiles on colonic function--randomised and double-blind clinical trial in infants aged } \\
\text { between } 6 \text { and } 12 \text { months--pilot study. Eur J Pediatr.2013;172:1535-42. }\end{array}$ & IV \\
\hline 54 & $\begin{array}{l}\text { Berni Canani R,Nocerino R,Terrin G,Frediani T,Lucarelli S,Cosenza L,Passariello A,Leone L,Granata V,Di Costanzo } \\
\text { M,Pezzella V,Troncone R. Formula selection for management of children with cow's milk allergy influences the rate of } \\
\text { acquisition of tolerance: a prospective multicenter study. J Pediatr.2013;163:771-7.e1. }\end{array}$ & IV, DV \\
\hline 55 & $\begin{array}{l}\text { Betoko, A.,Charles, M. A.,Hankard, R.,Forhan, A.,Bonet, M.,Regnault, N.,Botton, J.,Saurel-Cubizolles, M. J.,de Lauzon- } \\
\text { Guillain, B. Determinants of infant formula use and relation with growth in the first } 4 \text { months. Matern Child } \\
\text { Nutr.2014;10:267-79. }\end{array}$ & IV \\
\hline 56 & $\begin{array}{l}\text { Betoko, A.,Charles, M. A.,Hankard, R.,Forhan, A.,Bonet, M.,Saurel-Cubizolles, M. J.,Heude, B.,de Lauzon-Guillain, B. } \\
\text { Infant feeding patterns over the first year of life: influence of family characteristics. Eur J Clin Nutr.2013;67:631-7. }\end{array}$ & DV \\
\hline 57 & $\begin{array}{l}\text { Bhandari, N.,Bahl, R.,Nayyar, B.,Khokhar, P.,Rohde, J. E.,Bhan, M. K. Food supplementation with encouragement to feed } \\
\text { it to infants from } 4 \text { to } 12 \text { months of age has a small impact on weight gain. J Nutr.2001;131:1946-51. }\end{array}$ & Country \\
\hline 58 & $\begin{array}{l}\text { Bhandari, N.,Mazumder, S.,Bahl, R.,Martines, J.,Black, R. E.,Bhan, M. K. An educational intervention to promote } \\
\text { appropriate complementary feeding practices and physical growth in infants and young children in rural Haryana, India. J }\end{array}$ & IV \\
\hline
\end{tabular}


59 Bhatia, B. D.,Banerjee, D.,Agarwal, D. K.,Agarwal, K. N. Exterogestate growth: relationship with maternal body size and dietary intakes. Indian J Pediatr.1983;50:241-6.

60 Bindon, J. R.,Cabrera, C. Infant feeding patterns and growth of infants in American Samoa during the first year of life. Hum Biol.1988;60:81-92.

61 Bindon, J. R. The body build and composition of Samoan children: relationships to infant feeding patterns and infant weight-for-length status. Am J Phys Anthropol.1984;63:379-88.

62 Bindon, J. R. The influence of infant feeding patterns on growth of children in American Samoa. Med Anthropol.1985;9:183-95.

63 Birch,E. E.,Garfield,S.,Castaneda,Y.,Hughbanks-Wheaton,D.,Uauy,R.,Hoffman,D. Visual acuity and cognitive outcomes at 4 years of age in a double-blind, randomized trial of long-chain polyunsaturated fatty acid-supplemented infant formula. Early Hum Dev.2007;83:279-84.

64 Bisimwa, G.,Owino, V. O.,Bahwere, P.,Dramaix, M.,Donnen, P.,Dibari, F.,Collins, S. Randomized controlled trial of the effectiveness of a soybean-maize-sorghum-based ready-to-use complementary food paste on infant growth in South Kivu, Democratic Republic of Congo. Am J Clin Nutr.2012;95:1157-64.

65 Bjorke-Monsen, A. L. Is exclusive breastfeeding ensuring an optimal micronutrient status and psychomotor development in infants?. Clin Biochem.2014;47:714.

66 Block,S. L. Delayed introduction of solid foods to infants: not so fast!. Pediatr Ann.2013;42:143-7.

67 Bogen, D. L.,Hanusa, B. H.,Whitaker, R. C. The effect of breast-feeding with and without formula use on the risk of obesity
at 4 years of age. Obes Res.2004;12:1527-35.

67 Bogen, D. L.,Hanusa, B. H.,Whitaker, R. C. The effect of breast-feeding with and without formula use on the risk of obesity
at 4 years of age. Obes Res.2004;12:1527-35.

68 Bonuck, K.,Avraham, S. B.,Lo, Y.,Kahn, R.,Hyden, C. Bottle-weaning intervention and toddler overweight. J Pediatr.2014;164:306-12.e1-2.

69 Borschel, M. W.,Baggs, G. E.,Barrett-Reis, B. Growth of healthy term infants fed ready-to-feed and powdered forms of an extensively hydrolyzed casein-based infant formula: a randomized, blinded, controlled trial. Clin Pediatr (Phila).2014;53:585-92.

70 Boulton J. Nutrition in childhood and its relationships to early somatic growth, body fat, blood pressure, and physical fitness. Acta Paediatr Scand Suppl.1981;284:1-85.

71 Brakohiapa, L. A.,Yartey, J.,Bille, A.,Harrison, E.,Quansah, E.,Armar, M. A.,Kishi, K.,Yamamoto, S. Does prolonged breastfeeding adversely affect a child's nutritional status?. Lancet.1988;2:416-8.

72 Brazionis, L.,Golley, R. K., Mittinty, M. N.,Smithers, L. G.,Emmett, P.,Northstone, K.,Lynch, J. W. Diet spanning infancy and toddlerhood is associated with child blood pressure at age 7.5 y. Am J Clin Nutr.2013;97:1375-86.

73 Breij, L. M.,Mulder, M. T.,van Vark-van der Zee, L. C.,Hokken-Koelega, A. C. Appetite-regulating hormones in early life and relationships with type of feeding and body composition in healthy term infants. Eur J Nutr.2016.

Design

Health

status, IV

Design, IV, DV

IV

Country

IV

Design

V

IV

IV

Design, DV

IV, DV

DV

IV 
74 Brekke, H. K.,van Odijk, J.,Ludvigsson, J. Predictors and dietary consequences of frequent intake of high-sugar, lownutrient foods in 1-year-old children participating in the ABIS study. Br J Nutr.2007;97:176-81.

75 Brew,B. K., Toelle,B. G.,Webb,K. L.,Almqvist,C.,Marks,G. B. Omega-3 supplementation during the first 5 years of life and later academic performance: a randomised controlled trial. Eur J Clin Nutr.2015;69:419-24.

76 Briend,A.,Bari,A. Breastfeeding improves survival, but not nutritional status, of 12-35 months old children in rural Bangladesh. Eur J Clin Nutr.1989;43:603-8.

77 Briend,A.,Darmon,N. Determining limiting nutrients by linear programming: A new approach to predict insufficient intakes from complementary foods. Pediatrics.2000;106:1288-9.

78 Brito,A.,Olivares,M.,Pizarro,T.,Rodriguez,L.,Hertrampf,E. Chilean complementary feeding program reduces anemia and improves iron status in children aged 11 to 18 months. Food Nutr Bull.2013;34:378-85.

79 Brown A,Lee MD. Early influences on child satiety-responsiveness: the role of weaning style. Pediatr Obes.2015;10:57-66.

80 Brown, A.,Lee, M. Breastfeeding during the first year promotes satiety responsiveness in children aged 18-24 months. Pediatr Obes.2012;7:382-90.

81 Brown,K. H.,Lopez de Romana,D.,Arsenault,J. E.,Peerson,J. M.,Penny,M. E. Comparison of the effects of zinc delivered in a fortified food or a liquid supplement on the growth, morbidity, and plasma zinc concentrations of young Peruvian children. Am J Clin Nutr.2007;85:538-47.

82 Brown,L. V.,Zeitlin,M. F.,Peterson,K. E.,Chowdhury,A. M.,Rogers,B. L.,Weld,L. H.,Gershoff,S. N. Evaluation of the impact of weaning food messages on infant feeding practices and child growth in rural Bangladesh. Am J Clin Nutr.1992;56:9941003. disorders. Pediatr Rev.2009;30:e29-33.

84 Bulk-Bunschoten, A. M.,van Bodegom, S.,Reerink, J. D.,de Jong, P. C.,de Groot, C. J. Weight and weight gain at 4 months (The Netherlands 1998): influences of nutritional practices, socio-economic and ethnic factors. Paediatr Perinat Epidemiol.2002;16:361-9.

85 Burnham, L.,Matlak, S.,Makrigiorgos, G.,Braun, N.,Knapp, B. P.,Merewood, A. Breastfeeding and coffee consumption in children younger than 2 years in Boston, Massachusetts, USA. J Hum Lact.2015;31:267-72.

86 Caleyachetty A,Krishnaveni GV,Veena SR,Hill J,Karat SC,Fall CH,Wills AK. Breastfeeding duration, age of starting solids and high BMI risk and adiposity in Indian children. Matern Child Nutr.2013;9:199-216. 87 Calvo,E. B.,Galindo,A. C.,Aspres,N. B. Iron status in exclusively breast-fed infants. Pediatrics.1992;90:375-9.

Design

Design

IV

IV

IV

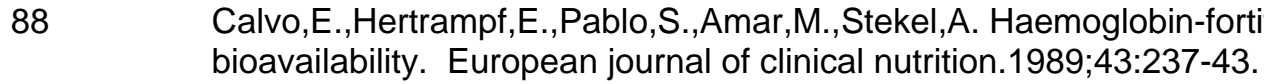

89 Cameron, S. L.,Heath, A. L., Gray, A. R.,Churcher, B.,Davies, R. S.,Newlands, A., Galland, B. C.,Sayers, R. M.,Lawrence, J.

A., Taylor, B. J., Taylor, R. W. Lactation Consultant Support from Late Pregnancy with an Educational Intervention at 4

DV

Design,

Country

IV, DV 
Months of Age Delays the Introduction of Complementary Foods in a Randomized Controlled Trial. J Nutr.2015;145:1481-

90.

90 Capozzi,L.,Russo,R.,Bertocco,F.,Ferrara,D.,Ferrara,M. Diet and iron deficiency in the first year of life: a retrospective study.

DV Hematology.2010;15:410-3.

91 Capozzi,L.,Russo,R.,Bertocco,F.,Ferrara,D.,Ferrara,M. Effect on haematological and anthropometric parameters of iron supplementation in the first 2 years of life. Risks and benefits. Hematology.2011;16:261-4.

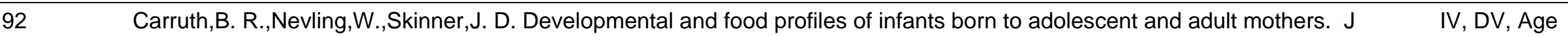
Adolesc Health.1997;20:434-41.

93 Casiday, R. E.,Wright, C. M.,Panter-Brick, C.,Parkinson, K. N. Do early infant feeding patterns relate to breast-feeding continuation and weight gain? Data from a longitudinal cohort study. Eur J Clin Nutr.2004;58:1290-6.

94 Castillo-Duran,C.,Perales,C. G.,Hertrampf,E. D.,Marin,V. B.,Rivera,F. A.,Icaza,G. Effect of zinc supplementation on development and growth of Chilean infants. J Pediatr.2001;138:229-35.

95 Chaimay, B.,Ruagdaraganon, N.,Thinkhamrop, B., Thinkhamrop, J. Association between infant feeding practices and first meaningful words at first year of life: a prospective cohort study of Thai children. Asia Pac J Public Health.2015;27:Np1071-84.

96 Chan,G. M.,Roberts,C. C.,Folland,D.,Jackson,R. Growth and bone mineralization of normal breast-fed infants and the effects of lactation on maternal bone mineral status. Am J Clin Nutr.1982;36:438-43.

97 Chang, S. Y.,He, W.,Chen, C. M. Complementary feeding and growth of infant and young child in China. Biomed Environ Sci.2008;21:264-8.

$98 \quad$ Chatterjee, M. K. Feeding pattern practised by the mothers attending an under five clinic. Indian J Public Health.1987;31:268-9.

99 Chavez A,Martinez C,Schlaepfer L. Health effects of supplementary feeding programs. Prog Clin Biol Res.1981;67:12939.

100 Chawla, P.,Puri, R.,Pershad, D. Impact of pre-school supplementary feeding on mental abilities. Indian Pediatr.1983;20:513-6.

101 Chawla, P.,Puri, R. Impact of pre-school supplementary feeding programme on anthropometry. Indian Pediatr.1983;20:363-7. Clin Nutr.2016;103:398-405.

103 Chirmulay, D.,Nisal, R. Nutritional status of tribal underfive children in Ahmadnagar District, Maharashtra in relation to weaning/feeding practices. Indian Pediatr.1993;30:215-22. 
105 Chivers, P.,Hands, B.,Parker, H.,Bulsara, M.,Beilin, L. J.,Kendall, G. E.,Oddy, W. H. Body mass index, adiposity rebound and early feeding in a longitudinal cohort (Raine Study). Int J Obes (Lond).2010;34:1169-76.

106 Cho, H. N.,Hong, S.,Lee, S. H.,Yum, H. Y. Nutritional status according to sensitized food allergens in children with atopic dermatitis. Allergy, Asthma and Immunology Research.2010;3:53-57.

Design, IV

107 Chorell,E.,Karlsson Videhult,F.,Hernell,O.,Antti,H.,West,C. E. Impact of probiotic feeding during weaning on the serum lipid IV DV profile and plasma metabolome in infants. Br J Nutr.2013;110:116-26.

108 Choudhury, N.,Bromage, S.,Alam, M. A.,Ahmed, A. M.,Islam, M. M.,Hossain, M. I.,Mahfuz, M.,Mondal, D.,Haque, M. R.,Ahmed, T. Intervention study shows suboptimal growth among children receiving a food supplement for five months in a slum in Bangladesh. Acta Paediatr.2016.

109 Christoffel, K. A pediatric perspective on vegetarian nutrition. Clin Pediatr (Phila).1981;20:632-43.

110 Christopher, G. C. First food: the essential role of breastfeeding. Breastfeed Med.2009;4 Suppl 1:S9-s10.

111 Chuang, C. H.,Yang, S. H.,Chang, P. J.,Chen, P. C., Chen, Y. C. Dietary supplement intake by 6-month-old Taiwanese infants. J Pediatr Gastroenterol Nutr.2012;54:71-6.

112 Closa-Monasterolo, R.,Gispert-Llaurado, M.,Luque, V.,Ferre, N.,Rubio-Torrents, C.,Zaragoza-Jordana, M.,Escribano, J. Safety and efficacy of inulin and oligofructose supplementation in infant formula: results from a randomized clinical trial. Clin Nutr.2013;32:918-27.

113 Cloutier, M. M.,Wiley, J.,Wang, Z., Grant, A., Gorin, A. A. The Early Childhood Obesity Prevention Program (ECHO): an ecologically-based intervention delivered by home visitors for newborns and their mothers. BMC Public Health.2015;15:584.

114 Cockburn,F. Neonatal brain and dietary lipids. Arch Dis Child Fetal Neonatal Ed.1994;70:F1-2.

115 Cohen RJ,Brown KH,Canahuati J,Rivera LL,Dewey KG. Effects of age of introduction of complementary foods on infant breast milk intake, total energy intake, and growth: a randomised intervention study in Honduras. Lancet.1994;344:288-93.

116 Cohen, R. J.,Brown, K. H.,Canahuati, J.,Rivera, L. L.,Dewey, K. G. Determinants of growth from birth to 12 months among breast-fed Honduran infants in relation to age of introduction of complementary foods. Pediatrics.1995;96:504-10.

117 Coleman,B. L. Early introduction of non-formula cow's milk to southern Ontario infants. Can J Public Health.2006;97:18790.

118 Colombo,J.,Carlson,S. E.,Cheatham,C. L.,Shaddy,D. J.,Kerling,E. H., Thodosoff,J. M.,Gustafson,K. M.,Brez,C. Long-term effects of LCPUFA supplementation on childhood cognitive outcomes. Am J Clin Nutr.2013;98:403-12.

119 Coppi, S.,lacoponi, F.,Fommei, C.,Strambi, M. Growth trend during the first six months of life in male infants with different type of feeding. Minerva Pediatr.2013;65:51-9.

120 Costom, B. H.,Shore, D. Effect of a comprehensive nutritional program on the growth and ponderosity of infants. Clin Pediatr (Phila).1983;22:105-11. 
Visual acuity development and fatty acid composition of erythrocytes in full-term infants fed breast milk, commercial formula, or evaporated milk. J Dev Behav Pediatr.1998;19:9-17.

122 Cusack, R. Dietary management of obese children and adolescents. Pediatr Ann.1984;13:455, 458-9, 462-4.

123 Dagan, R.,Sofer, S.,Klish, W. J.,Hundt, G.,Saltz-Rennert, H.,Moses, S. W. Infant feeding practices among Bedouins in transition from seminomadic to settlement conditions in the Negev area of Israel. Isr J Med Sci.1984;20:1029-34.

124 Dagnelie,P. C.,van Staveren,W. A.,Hautvast,J. G. Stunting and nutrient deficiencies in children on alternative diets. Acta Paediatr Scand Suppl.1991;374:111-8.

125 Dagnelie,P. C.,van Staveren,W. A.,Vergote,F. J.,Dingjan,P. G.,van den Berg,H.,Hautvast,J. G. Increased risk of vitamin B12 and iron deficiency in infants on macrobiotic diets. Am J Clin Nutr.1989;50:818-24.

126 Dagnelie,P. C.,van Staveren,W. A., Verschuren,S. A.,Hautvast,J. G. Nutritional status of infants aged 4 to 18 months on macrobiotic diets and matched omnivorous control infants: a population-based mixed-longitudinal study. I. Weaning pattern, energy and nutrient intake. Eur J Clin Nutr.1989;43:311-23.

127 Daniels, L. A.,Mallan, K. M.,Battistutta, D.,Nicholson, J. M.,Meedeniya, J. E.,Bayer, J. K.,Magarey, A. Child eating behavior outcomes of an early feeding intervention to reduce risk indicators for child obesity: the NOURISH RCT. Obesity (Silver Spring).2014;22:E104-11.

128 Daniels, L. A.,Mallan, K. M.,Battistutta, D.,Nicholson, J. M.,Perry, R., Magarey, A. Evaluation of an intervention to promote protective infant feeding practices to prevent childhood obesity: outcomes of the NOURISH RCT at 14 months of age and 6 months post the first of two intervention modules. Int J Obes (Lond).2012;36:1292-8.

129 Daniels, L. A.,Mallan, K. M.,Nicholson, J. M.,Battistutta, D.,Magarey, A. Outcomes of an early feeding practices intervention to prevent childhood obesity. Pediatrics.2013;132:e109-18.

130 Daniels, L. A., Mallan, K. M.,Nicholson, J. M.,Thorpe, K.,Nambiar, S.,Mauch, C. E.,Magarey, A. An Early Feeding Practices Intervention for Obesity Prevention. Pediatrics.2015;136:e40-9.

131 Daniels, M. C.,Adair, L. S. Breast-feeding influences cognitive development in Filipino children. J Nutr.2005;135:2589-95.

132 Davidsson,L.,Sarker,S. A.,Jamil,K. A.,Sultana,S.,Hurrell,R. Regular consumption of a complementary food fortified with ascorbic acid and ferrous fumarate or ferric pyrophosphate is as useful as ferrous sulfate in maintaining hemoglobin concentrations >105 g/L in young Bangladeshi children. Am J Clin Nutr.2009;89:1815-20.

133 de Hoog ML,van Eijsden M,Stronks K,Gemke RJ,Vrijkotte TG. The role of infant feeding practices in the explanation for ethnic differences in infant growth: the Amsterdam Born Children and their Development study. Br J Nutr.2011;106:1592601.

134 de Kanashiro, H. C.,Brown, K. H.,Lopez de Romana, G.,Lopez, T.,Black, R. E. Consumption of food and nutrients by infants in Huascar (Lima), Peru. Am J Clin Nutr.1990;52:995-1004.

135 de Villiers, A., Senekal, M. Determinants of growth failure in 12-24-month-old children in a high-density urban slum community in East London, South Africa. Eur J Clin Nutr.2002;56:1231-41. 
139 Dewey, K. G.,Hawck, M. G.,Brown, K. H.,Lartey, A.,Cohen, R. J.,Peerson, J. M. Infant weight-for-length is positively associated with subsequent linear growth across four different populations. Matern Child Nutr.2005;1:11-20.

140 Dewey, K. G.,Heinig, M. J.,Nommsen, L. A.,Lonnerdal, B. Adequacy of energy intake among breast-fed infants in the DARLING study: relationships to growth velocity, morbidity, and activity levels. Davis Area Research on Lactation, Infant Nutrition and Growth. J Pediatr.1991;119:538-47.

141 Dewey, K. G.,Lonnerdal, B. Milk and nutrient intake of breast-fed infants from 1 to 6 months: relation to growth and fatness. J Pediatr Gastroenterol Nutr.1983;2:497-506.

142 Dewey, K. G.,Peerson, J. M.,Brown, K. H.,Krebs, N. F.,Michaelsen, K. F.,Persson, L. A.,Salmenpera, L.,Whitehead, R. G.,Yeung, D. L. Growth of breast-fed infants deviates from current reference data: a pooled analysis of US, Canadian, and European data sets. World Health Organization Working Group on Infant Growth. Pediatrics.1995;96:495-503.

143 Dewey, K. G.,Peerson, J. M.,Heinig, M. J.,Nommsen, L. A.,Lonnerdal, B.,Lopez de Romana, G.,de Kanashiro, H. C.,Black, R. E.,Brown, K. H. Growth patterns of breast-fed infants in affluent (United States) and poor (Peru) communities: implications for timing of complementary feeding. Am J Clin Nutr.1992;56:1012-8.

144 Dewey, K. G. Complementary feeding and infant growth and body composition. Pediatrics.2000;106:1281.

145 Dewey,K. G.,Cohen,R. J.,Brown,K. H.,Rivera,L. L. Effects of exclusive breastfeeding for four versus six months on Country maternal nutritional status and infant motor development: results of two randomized trials in Honduras. $\mathrm{J}$ Nutr.2001;131:262-7.

146 Dewey,K. G.,Cohen,R. J.,Rivera,L. L.,Brown,K. H. Effects of age of introduction of complementary foods on iron status of breast-fed infants in Honduras. Am J Clin Nutr.1998;67:878-84.

147 Dewey,K. G.,Huffman,S. L. Maternal, infant, and young child nutrition: combining efforts to maximize impacts on child growth and micronutrient status. Food Nutr Bull.2009;30:S187-9.

148 Dewey,K. G.,Romero-Abal,M. E.,Quan de Serrano,J.,Bulux,J.,Peerson,J. M.,Eagle,P.,Solomons,N. W. Effects of discontinuing coffee intake on iron status of iron-deficient Guatemalan toddlers: a randomized intervention study. Am J Clin Nutr.1997;66:168-76.

149 Diaz, S.,Herreros, C.,Aravena, R.,Casado, M. E.,Reyes, M. V.,Schiappacasse, V. Breast-feeding duration and growth of fully breast-fed infants in a poor urban Chilean population. Am J Clin Nutr.1995;62:371-6.

150 Doak, C. M.,van der Starre, R. E.,van Beusekom, I.,Campos Ponce, M.,Vossenaar, M.,Solomons, N. W. Earlier introduction of aguitas is associated with higher risk of stunting in infants and toddlers in the Western Highlands of

DV

Design

DV 


\begin{tabular}{|c|c|c|}
\hline 151 & $\begin{array}{l}\text { Domellof,M.,Cohen,R. J.,Dewey,K. G.,Hernell,O.,Rivera,L. L.,Lonnerdal,B. Iron supplementation of breast-fed Honduran } \\
\text { and Swedish infants from } 4 \text { to } 9 \text { months of age. J Pediatr.2001;138:679-87. }\end{array}$ & IV, DV \\
\hline 152 & $\begin{array}{l}\text { Dong,C.,Ge,P.,Ren,X.,Wang,J.,Fan, H.,Yan,X.,Yin,S. A. Prospective study on the effectiveness of complementary food } \\
\text { supplements on improving status of elder infants and young children in the areas affected by Wenchuan earthquake. PLoS } \\
\text { One.2013;8:e72711. }\end{array}$ & $\begin{array}{l}\text { Design, } \\
\text { Health } \\
\text { status }\end{array}$ \\
\hline 153 & $\begin{array}{l}\text { Donma, M. M.,Donma, O. Infant feeding and growth: a study on Turkish infants from birth to } 6 \text { months. Pediatr } \\
\text { Int.1999;41:542-8. }\end{array}$ & IV \\
\hline 154 & $\begin{array}{l}\text { Donma, M. M.,Donma, O. The influence of feeding patterns on head circumference among Turkish infants during the first } 6 \\
\text { months of life. Brain Dev.1997;19:393-7. }\end{array}$ & IV \\
\hline 155 & $\begin{array}{l}\text { Dubakiene, R.,Rudzeviciene, O.,Butiene, I.,Sezaite, I.,Petronyte, M.,Vaicekauskaite, D.,Zvirbliene, A. Studies on early } \\
\text { allergic sensitization in the Lithuanian birth cohort. ScientificWorldJournal.2012;2012:909524. }\end{array}$ & IV, DV \\
\hline 156 & $\begin{array}{l}\text { Dubois, L.,Girard, M. Breast-feeding, day-care attendance and the frequency of antibiotic treatments from } 1.5 \text { to } 5 \text { years: a } \\
\text { population-based longitudinal study in Canada. Soc Sci Med.2005;60:2035-44. }\end{array}$ & IV, DV \\
\hline 157 & $\begin{array}{l}\text { Dubois, L.,Girard, M. Social inequalities in infant feeding during the first year of life. The Longitudinal Study of Child } \\
\text { Development in Quebec (LSCDQ 1998-2002). Public Health Nutr.2003;6:773-83. }\end{array}$ & IV, DV \\
\hline 158 & $\begin{array}{l}\text { Dubowitz, T.,Levinson, D.,Peterman, J. N.,Verma, G.,Jacob, S.,Schultink, W. Intensifying efforts to reduce child } \\
\text { malnutrition in India: an evaluation of the Dular program in Jharkhand, India. Food Nutr Bull.2007;28:266-73. }\end{array}$ & IV \\
\hline 159 & $\begin{array}{l}\text { Duggan,C.,Penny,M. E.,Hibberd,P.,Gil,A.,Huapaya,A.,Cooper,A.,Coletta,F.,Emenhiser,C.,Kleinman,R. E. Oligofructose- } \\
\text { supplemented infant cereal: } 2 \text { randomized, blinded, community-based trials in Peruvian infants. Am J Clin } \\
\text { Nutr.2003;77:937-42. }\end{array}$ & IV \\
\hline 160 & $\begin{array}{l}\text { Dunne,A. Nutrition in infancy: achieving nutrition needs for new mothers and children. Br J Community } \\
\text { Nurs.2012;Suppl:S22. }\end{array}$ & Design \\
\hline 161 & Edmondson, L. What toddlers eat really matters. J Fam Health Care.2011;21:33-41. & Design \\
\hline 162 & $\begin{array}{l}\text { El-Sayed H,Martines J,Rakha M,Zekry O,Abdel-Hak M,Abbas H. The effectiveness of the WHO training course on } \\
\text { complementary feeding counseling in a primary care setting, Ismailia, Egypt. J Egypt Public Health Assoc.2014;89:1-8. }\end{array}$ & IV \\
\hline 163 & $\begin{array}{l}\text { Elwood, P. C., Haley, T. J.,Hughes, S. J.,Sweetnam, P. M.,Gray, O. P.,Davies, D. P. Child growth (0-5 years), and the effect } \\
\text { of entitlement to a milk supplement. Arch Dis Child.1981;56:831-5. }\end{array}$ & IV \\
\hline 164 & $\begin{array}{l}\text { Emmett,P. M.,Jones,L. R. Diet and growth in infancy: relationship to socioeconomic background and to health and } \\
\text { development in the Avon Longitudinal Study of Parents and Children. Nutr Rev.2014;72:483-506. }\end{array}$ & Design \\
\hline 165 & $\begin{array}{l}\text { Emond A,Drewett R,Blair P,Emmett P. Postnatal factors associated with failure to thrive in term infants in the Avon } \\
\text { Longitudinal Study of Parents and Children. Arch Dis Child.2007;92:115-9. }\end{array}$ & IV \\
\hline
\end{tabular}




\begin{tabular}{|c|c|c|}
\hline 166 & $\begin{array}{l}\text { Eneroth,H.,El Arifeen,S.,Persson,L. A.,Kabir,I.,Lonnerdal,B.,Hossain,M. B.,Ekstrom,E. C. Duration of exclusive breast- } \\
\text { feeding and infant iron and zinc status in rural Bangladesh. J Nutr.2009;139:1562-7. }\end{array}$ & IV, DV \\
\hline 167 & $\begin{array}{l}\text { Engelmann,M. D.,Davidsson,L.,Sandstrom,B.,Walczyk, T.,Hurrell,R. F.,Michaelsen,K. F. The influence of meat on nonheme } \\
\text { iron absorption in infants. Pediatr Res.1998;43:768-73. }\end{array}$ & DV \\
\hline 168 & $\begin{array}{l}\text { England, L.,Brenner, R.,Bhaskar, B.,Simons-Morton, B.,Das, A.,Revenis, M.,Mehta, N.,Clemens, J. Breastfeeding practices } \\
\text { in a cohort of inner-city women: the role of contraindications. BMC Public Health.2003;3:28. }\end{array}$ & IV, DV \\
\hline 169 & $\begin{array}{l}\text { Escribano, J.,Luque, V.,Ferre, N.,Mendez-Riera, G.,Koletzko, B.,Grote, V.,Demmelmair, H.,Bluck, L.,Wright, A.,Closa- } \\
\text { Monasterolo, R. Effect of protein intake and weight gain velocity on body fat mass at } 6 \text { months of age: the EU Childhood } \\
\text { Obesity Programme. Int J Obes (Lond).2012;36:548-53. }\end{array}$ & IV \\
\hline 170 & $\begin{array}{l}\text { Esfarjani, F.,Azar, M. R.,Gafarpour, M. IDDM and early exposure of infant to cow's milk and solid food. Indian J } \\
\text { Pediatr.2001;68:107-10. }\end{array}$ & DV \\
\hline 171 & $\begin{array}{l}\text { Evans, D.,Hansen, J. D.,Moodie, A. D.,van der Spuy, H. I. Intellectual development and nutrition. J Pediatr.1980;97:358- } \\
63 .\end{array}$ & $\begin{array}{l}\text { Health } \\
\text { status, IV }\end{array}$ \\
\hline 172 & $\begin{array}{l}\text { ExI, B. M.,Deland, U.,Secretin, M. C.,Preysch, U.,Wall, M.,Shmerling, D. H. Improved general health status in an } \\
\text { unselected infant population following an allergen reduced dietary intervention programme. The ZUFF-study-programme. } \\
\text { Part I: Study design and 6-month nutritional behaviour. Eur J Nutr.2000;39:89-102. }\end{array}$ & DV \\
\hline 173 & $\begin{array}{l}\text { Exl, B. M.,Deland, U.,Secretin, M. C.,Preysch, U.,Wall, M.,Shmerling, D. H. Improved general health status in an } \\
\text { unselected infant population following an allergen-reduced dietary intervention programme: the ZUFF-STUDY- } \\
\text { PROGRAMME. Part II: infant growth and health status to age } 6 \text { months. ZUg-FrauenFeld. Eur J Nutr.2000;39:145-56. }\end{array}$ & IV \\
\hline 174 & $\begin{array}{l}\text { Faber,M.,Kvalsvig,J. D.,Lombard,C. J.,Benade,A. J. Effect of a fortified maize-meal porridge on anemia, micronutrient } \\
\text { status, and motor development of infants. Am J Clin Nutr.2005;82:1032-9. }\end{array}$ & Country \\
\hline 175 & $\begin{array}{l}\text { Faber,M. Dietary intake and anthropometric status differ for anaemic and non-anaemic rural South African infants aged 6- } \\
12 \text { months. J Health Popul Nutr.2007;25:285-93. }\end{array}$ & Design \\
\hline 176 & $\begin{array}{l}\text { Fabiansen, C.,Phelan, K. P.,Cichon, B.,Ritz, C.,Briend, A.,Michaelsen, K. F.,Friis, H.,Shepherd, S. Short children with a low } \\
\text { midupper arm circumference respond to food supplementation: an observational study from Burkina Faso. Am J Clin } \\
\text { Nutr.2016;103:415-21. }\end{array}$ & $\begin{array}{l}\text { Health } \\
\text { status }\end{array}$ \\
\hline 177 & $\begin{array}{l}\text { Fabius, R. J.,Merritt, R. J.,Fleiss, P. M.,Ashley, J. M. Malnutrition associated with a formula of barley water, corn syrup, and } \\
\text { whole milk. Am J Dis Child.1981;135:615-7. }\end{array}$ & Design \\
\hline 178 & Falkner, F. Introduction of food to infants. Genetic-environmental considerations. Am J Clin Nutr.1985;41:436-9. & Design \\
\hline 179 & $\begin{array}{l}\text { Fall } \mathrm{CH} \text {,Borja JB,Osmond C,Richter L,Bhargava SK,Martorell R,Stein AD,Barros FC,Victora CG. Infant-feeding patterns } \\
\text { and cardiovascular risk factors in young adulthood: data from five cohorts in low- and middle-income countries. Int J } \\
\text { Epidemiol.2011;40:47-62. }\end{array}$ & Design \\
\hline 180 & $\begin{array}{l}\text { Farris, R. P.,Frank, G. C.,Webber, L. S.,Srinivasan, S. R.,Berenson, G. S. Influence of milk source on serum lipids and } \\
\text { lipoproteins during the first year of life, Bogalusa heart study. Am J Clin Nutr.1982;35:42-9. }\end{array}$ & IV \\
\hline
\end{tabular}




\begin{tabular}{|c|c|c|}
\hline 181 & $\begin{array}{l}\text { Farrow, C. V.,Blissett, J. Controlling feeding practices: cause or consequence of early child weight?. } \\
\text { Pediatrics.2008;121:e164-9. }\end{array}$ & IV \\
\hline 182 & $\begin{array}{l}\text { Farrow, C.,Blissett, J. Does maternal control during feeding moderate early infant weight gain?. Pediatrics.2006;118:e293- } \\
8 .\end{array}$ & IV \\
\hline 183 & Fawcett, J. N. Feeding from birth to 18 months. Nursing (Lond).1981:956-8. & Design \\
\hline 184 & $\begin{array}{l}\text { Feldens CA,Vitolo MR, Rauber F,Cruz LN,Hilgert JB. Risk factors for discontinuing breastfeeding in southern Brazil: a } \\
\text { survival analysis. Matern Child Health J.2012;16:1257-65. }\end{array}$ & IV, DV \\
\hline 185 & $\begin{array}{l}\text { Feldens, C. A.,Ardenghi, T. M.,Cruz, L. N.,Scalco, G. P.,Vitolo, M. R. Advising mothers about breastfeeding and weaning } \\
\text { reduced pacifier use in the first year of life: a randomized trial. Community Dent Oral Epidemiol.2013;41:317-26. }\end{array}$ & IV, DV \\
\hline 186 & $\begin{array}{l}\text { Feldens, C. A.,Kramer, P. F.,Sequeira, M. C.,Rodrigues, P. H.,Vitolo, M. R. Maternal education is an independent } \\
\text { determinant of cariogenic feeding practices in the first year of life. Eur Arch Paediatr Dent.2012;13:70-5. }\end{array}$ & DV \\
\hline 187 & $\begin{array}{l}\text { Fergusson, D. M.,Woodward, L. J. Breast feeding and later psychosocial adjustment. Paediatr Perinat } \\
\text { Epidemiol.1999;13:144-57. }\end{array}$ & IV \\
\hline 188 & $\begin{array}{l}\text { Fernandes, T. A.,Werneck, G. L.,Hasselmann, M. H. Prepregnancy weight, weight gain during pregnancy, and exclusive } \\
\text { breastfeeding in the first month of Life in Rio de Janeiro, Brazil. J Hum Lact.2012;28:55-61. }\end{array}$ & IV, DV \\
\hline 189 & $\begin{array}{l}\text { Fernstrom, J. D.,Navia, J. L. Introduction to the workshop. Low-calorie sweeteners and weight control--what the science } \\
\text { tells us. J Nutr.2012;142:1132s-3s. }\end{array}$ & Design \\
\hline 190 & $\begin{array}{l}\text { Ferrara,M.,Bertocco,F.,Ricciardi,A.,Ferrara,D.,Incarnato,L.,Capozzi,L. Iron deficiency screening in the first three years of } \\
\text { life: a three-decade-long retrospective case study. Hematology.2014;19:239-43. }\end{array}$ & DV \\
\hline 191 & $\begin{array}{l}\text { Fildes, A.,van Jaarsveld, C. H.,Llewellyn, C.,Wardle, J.,Fisher, A. Parental control over feeding in infancy. Influence of } \\
\text { infant weight, appetite and feeding method. Appetite.2015;91:101-6. }\end{array}$ & IV, DV \\
\hline 192 & $\begin{array}{l}\text { Fisher, J. O.,Birch, L. L.,Smiciklas-Wright, H.,Picciano, M. F. Breast-feeding through the first year predicts maternal control } \\
\text { in feeding and subsequent toddler energy intakes. J Am Diet Assoc.2000;100:641-6. }\end{array}$ & IV, DV \\
\hline 193 & $\begin{array}{l}\text { Flax, V. L.,Bentley, M. E.,Chasela, C. S.,Kayira, D.,Hudgens, M. G.,Kacheche, K. Z., Chavula, C.,Kourtis, A. P.,Jamieson, } \\
\text { D. J.,van der Horst, C. M.,Adair, L. S. Lipid-based nutrient supplements are feasible as a breastmilk replacement for HIV- } \\
\text { exposed infants from } 24 \text { to } 48 \text { weeks of age. J Nutr.2013;143:701-7. }\end{array}$ & $\begin{array}{l}\text { Health } \\
\text { status, IV }\end{array}$ \\
\hline 194 & $\begin{array}{l}\text { Fomon SJ,Ziegler EE,Nelson SE,Edwards BB. Sweetness of diet and food consumption by infants. Proc Soc Exp Biol } \\
\text { Med.1983;173:190-3. }\end{array}$ & IV, DV \\
\hline 195 & $\begin{array}{l}\text { Fomon, S. J.,Rogers, R. R.,Ziegler, E. E.,Nelson, S. E.,Thomas, L. N. Indices of fatness and serum cholesterol at age eight } \\
\text { years in relation to feeding and growth during early infancy. Pediatr Res.1984;18:1233-8. }\end{array}$ & IV, Date \\
\hline 196 & $\begin{array}{l}\text { Forns,J.,Torrent,M.,Garcia-Esteban,R.,Caceres,A.,Pilar Gomila,M.,Martinez,D.,Morales,E.,Julvez,J.,Grimalt,J. O.,Sunyer,J. } \\
\text { Longitudinal association between early life socio-environmental factors and attention function at the age } 11 \text { years. Environ } \\
\text { Res.2012;117:54-9. }\end{array}$ & IV \\
\hline
\end{tabular}


197 Foroushani, A. R.,Mohammad, K.,Mahmoodi, M.,Siassi, F. Effect of breastfeeding on cognitive performance in a British birth cohort. East Mediterr Health J.2010;16:202-8.

198 Franks, A. J.,Jurgensen, C. Nutrition and health in the first year of life on a Pacific atoll. Observations on Abemama Atoll, Central Pacific. Trans R Soc Trop Med Hyg.1985;79:681-4.

199 Frederiksen,B. N.,Seifert,J.,Kroehl,M.,Lamb,M. M.,Milne,G. L.,Rewers,M.,Norris,J. M. Timing of solid food introduction is associated with urinary F2-isoprostane concentrations in childhood. Pediatric Research.2015;78:451-456.

200 Freeman, V.,van't Hof, M.,Haschke, F. Patterns of milk and food intake in infants from birth to age 36 months: the Eurogrowth study. J Pediatr Gastroenterol Nutr.2000;31 Suppl 1:S76-85.

201 Freeman,V. E.,Mulder,J.,van't Hof,M. A.,Hoey,H. M.,Gibney,M. J. A longitudinal study of iron status in children at 12, 24 and 36 months. Public Health Nutr.1998;1:93-100.

202 Friel,J. K.,Andrews,W. L.,Simmons,B. S.,L'Abbe,M. R.,Mercer,C.,MacDonald,A.,McCloy,U. R. Evaluation of full-term infants fed an evaporated milk formula. Acta Paediatr.1997;86:448-53.

203 Froozani, M. D.,Malekafzali, H.,Bahrini, B. Growth of a group of low income infants in the first year of life. J Trop Pediatr.1980;26:96-8.

204 Fuchs lii, G. J.,Gastanaduy, A. S.,Suskind, R. M. Comparative metabolic study of older infants fed infant formula, transition formula, or whole cow's milk. Nutrition Research.1992;12:1467-1478.

205 Fuchs, G. J.,Farris, R. P.,DeWier, M.,Hutchinson, S.,Strada, R.,Suskind, R. M. Effect of dietary fat on cardiovascular risk factors in infancy. Pediatrics.1994;93:756-63.

206 Gabriel, C. G.,Corso, A. C.,Caldeira, G. V.,Gimeno, S. G.,Schmitz Bde, A.,de Vasconcelos Fde, A. Overweight and obesity related factors in schoolchildren in Santa Catarina State, Brazil. Arch Latinoam Nutr.2010;60:332-9.

207 Gaffney, K. F.,Brito, A. V.,Kitsantas, P.,Kermer, D. A. Early Feeding Practices and Weight Status at One Year of Age: A Comparison of Hispanic Immigrant Mother-Infant Dyads with Participants of the Infant Feeding Practices Study II. Child Obes.2016.

208 Gale, C., Thomas, E. L.,Jeffries, S.,Durighel, G.,Logan, K. M.,Parkinson, J. R.,Uthaya, S., Santhakumaran, S.,Bell, J. D.,Modi, N. Adiposity and hepatic lipid in healthy full-term, breastfed, and formula-fed human infants: a prospective shortterm longitudinal cohort study. Am J Clin Nutr.2014;99:1034-40.

209 Galler, J. R.,Ramsey, F. C.,Harrison, R. H.,Brooks, R.,Weiskopf-Bock, S. Infant feeding practices in Barbados predict later growth. J Nutr.1998;128:1328-35.

210 Gallo PV. Physiological and behavioral consequences of maternal and post-weaning protein restriction. Physiol Behav.1981;26:77-84. breastfeeding extend beyond its own borders?. J Hum Lact.2013;29:128-31. 
monitoring growth from early pregnancy to 5 years of age. Breastfeed Med.2014;9:341-4.

213 Geuns, M.,Huisinga, C.,van Staveren, W. A.,Deurenberg, P.,Hautvast, J. G. Intakes of energy, protein and calcium and weaning pattern of a group of Dutch infants aged 6-12 months. Tijdschr Kindergeneeskd.1985;53:50-6.

214 Ghorashi,Z.,Nezami,N.,Ghalehgolab Behbahan,A.,Ghorashi,S. Supplemental food may not prevent iron-deficiency anemia in infants. Indian J Pediatr.2008;75:1121-4.

215 Ghosh,S.,Kilaru,A.,Ganapathy,S. Nutrition education and infant growth in rural Indian infants: narrowing the gender gap? J Indian Med Assoc.2002;100:483-4, 486-8, 490.

216 Gianni, M. L.,Roggero, P.,Morlacchi, L.,Garavaglia, E.,Piemontese, P.,Mosca, F. Formula-fed infants have significantly higher fat-free mass content in their bodies than breastfed babies. Acta Paediatr.2014;103:e277-81.

217 Gibson,R. S.,Hotz,C. The adequacy of micronutrients in complementary foods. Pediatrics.2000;106:1298-9.

Design, IV,

DV

DV

IV

IV

Design

218 Gill, D. G.,Vincent, S.,Segal Paediatr.1997;86:683-9.

219 Gillman, M. W.,Rifas-Shiman, S. L.,Camargo, C. A., Jr.,Berkey, C. S.,Frazier, A. L.,Rockett, H. R.,Field, A. E., Colditz, G. A. Risk of overweight among adolescents who were breastfed as infants. Jama.2001;285:2461-7.

220 Gokcay, G., Turan, J. M.,Partalci, A.,Neyzi, O. Growth of infants during the first year of life according to feeding regimen in the first 4 months. J Trop Pediatr.2003;49:6-12.

221 Golley,R. K.,Smithers,L. G.,Mittinty,M. N.,Brazionis,L.,Emmett,P.,Northstone,K.,Campbell,K.,McNaughton,S. A.,Lynch,J . W. An index measuring adherence to complementary feeding guidelines has convergent validity as a measure of infant diet quality. J Nutr.2012;142:901-8.

222 Gomez Santos, S. F.,Estevez Santiago, R.,Palacios Gil-Antunano, N.,Leis Trabazo, M. R., Tojo Sierra, R.,Cuadrado Vives, C.,Beltran de Miguel, B.,Avila Torres, J. M.,Varela Moreiras, G.,Casas Esteve, R. THAO-CHILD HEALTH PROGRAMME: COMMUNITY BASED INTERVENTION FOR HEALTHY LIFESTYLES PROMOTION TO CHILDREN AND FAMILIES: RESULTS OF A COHORT STUDY. Nutr Hosp.2015;32:2584-7.

223 Gomez-Sanchiz, M.,Canete, R.,Rodero, I.,Baeza, J. E.,Avila, O. Influence of breast-feeding on mental and psychomotor development. Clin Pediatr (Phila).2003;42:35-42.

224 Gomez-Sanchiz, M.,Canete, R.,Rodero, I.,Baeza, J. E.,Gonzalez, J. A. Influence of breast-feeding and parental intelligence on cognitive development in the 24-month-old child. Clin Pediatr (Phila).2004;43:753-61.

225 Gong, Y. H.,Ji, C. Y.,Zheng, X. X., Shan, J. P.,Hou, R. Correlation of 4-month infant feeding modes with their growth and iron status in Beijing. Chin Med J (Engl).2008;121:392-8.

226 Gooze, R. A.,Anderson, S. E.,Whitaker, R. C. Prolonged bottle use and obesity at 5.5 years of age in US children. J Pediatr.2011;159:431-6.

227 Greene, L. C.,Lucas, A.,Livingstone, M. B.,Harland, P. S.,Baker, B. A. Relationship between early diet and subsequent cognitive performance during adolescence. Biochem Soc Trans.1995;23:376s.
IV

Design

IV

IV, DV

Age

IV

IV

IV

Design, IV 
hydroxyvitamin D concentrations in breast-fed infants with and without supplemental vitamin D: one-year follow-up. J Pediatr.1982;100:919-22.

229 Grote, V.,von Kries, R.,Closa-Monasterolo, R.,Scaglioni, S.,Gruszfeld, D.,Sengier, A.,Langhendries, J. P.,Koletzko, B. Protein intake and growth in the first 24 months of life. J Pediatr Gastroenterol Nutr.2010;51 Suppl 3:S117-8.

230 Gruszfeld, D.,Weber, M.,Nowakowska-Rysz, M.,Janas, R.,Kozlik-Feldmann, R.,Xhonneux, A.,Carlier, C.,Riva, E.,Verduci, E.,Closa-Monasterolo, R.,Escribano, J.,Dobrzanska, A.,Koletzko, B. Protein intake in infancy and carotid intima media thickness at 5 years--a secondary analysis from a randomized trial. Ann Nutr Metab.2015;66:51-9.

231 Gubbels, J. S., Thijs, C., Stafleu, A.,van Buuren, S.,Kremers, S. P. Association of breast-feeding and feeding on demand with child weight status up to 4 years. Int J Pediatr Obes.2011;6:e515-22.

232 Gunderson, E. P.,Hurston, S. R.,Dewey, K. G.,Faith, M. S.,Charvat-Aguilar, N.,Khoury, V. C.,Nguyen, V. T.,Quesenberry, C. P., Jr. The study of women, infant feeding and type 2 diabetes after GDM pregnancy and growth of their offspring (SWIFT Offspring study): prospective design, methodology and baseline characteristics. BMC Pregnancy Childbirth.2015;15:150.

233 Gunnarsdottir I,Schack-Nielsen L,Michaelsen KF,Sorensen TI,Thorsdottir I. Infant weight gain, duration of exclusive breastfeeding and childhood BMI - two similar follow-up cohorts. Public Health Nutr.2010;13:201-7.

234 Gunnarsdottir, I., Thorsdottir, I. Relationship between growth and feeding in infancy and body mass index at the age of 6 years. Int J Obes Relat Metab Disord.2003;27:1523-7.

235 Gunther, A. L.,Buyken, A. E.,Kroke, A. Protein intake during the period of complementary feeding and early childhood and the association with body mass index and percentage body fat at 7 y of age. Am J Clin Nutr.2007;85:1626-33.

236 Gunther, A. L.,Buyken, A. E.,Kroke, A. The influence of habitual protein intake in early childhood on BMI and age at adiposity rebound: results from the DONALD Study. Int J Obes (Lond).2006;30:1072-9.

237 Gurnida, D. A.,Rowan, A. M.,Idjradinata, P.,Muchtadi, D.,Sekarwana, N. Association of complex lipids containing gangliosides with cognitive development of 6-month-old infants. Early Hum Dev.2012;88:595-601.

238 Hamilton, K.,Daniels, L.,White, K. M.,Murray, N.,Walsh, A. Predicting mothers' decisions to introduce complementary feeding at 6 months. An investigation using an extended theory of planned behaviour. Appetite.2011;56:674-81.

239 Hammer, L. D.,Bryson, S.,Agras, W. S. Development of feeding practices during the first 5 years of life. Arch Pediatr Adolesc Med.1999;153:189-94.

240 Han,Y. H.,Yon,M.,Han,H. S.,Johnston,K. E., Tamura,T.,Hyun,T. Zinc status and growth of Korean infants fed human milk, casein-based, or soy-based formula: three-year longitudinal study. Nutr Res Pract.2011;5:46-51.

241 Harbild, H. L.,Harslof, L. B., Christensen, J. H.,Kannass, K. N.,Lauritzen, L. Fish oil-supplementation from 9 to 12 months of age affects infant attention in a free-play test and is related to change in blood pressure. Prostaglandins Leukot Essent Fatty Acids.2013;89:327-33.

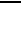


243 Harrington,M.,Hotz,C.,Zeder,C.,Polvo,G. O., Villalpando,S.,Zimmermann,M. B., Walczyk, T.,Rivera,J. A.,Hurrell,R. F. A comparison of the bioavailability of ferrous fumarate and ferrous sulfate in non-anemic Mexican women and children consuming a sweetened maize and milk drink. Eur J Clin Nutr.2011;65:20-5.

$244 \quad$ Harris,R. Inadequate diets: short- and long-term problems. J Fam Health Care.2002;12:6.

245 Hasan,J.,Ray,J.,Khan,Z. Role of weaning in the nutritional status of infant--a longitudinal study in the rural area of Aligarh. J Indian Med Assoc.1996;94:169, 215.

246 Haschke, F.,Pietschnig, B.,Vanura, H.,Heil, M.,Steffan, I.,Hobiger, G.,Schuster, E.,Camaya, Z. Iron intake and iron nutritional status of infants fed iron-fortified beikost with meat. Am J Clin Nutr.1988;47:108-12.

247 Hawley, N. L.,Johnson, W.,Nu'usolia, O.,McGarvey, S. T. The contribution of feeding mode to obesogenic growth trajectories in American Samoan infants. Pediatr Obes.2014;9:e1-e13.

248 Hay,G.,Johnston,C.,Whitelaw,A.,Trygg,K.,Refsum,H. Folate and cobalamin status in relation to breastfeeding and weaning DV in healthy infants. Am J Clin Nutr.2008;88:105-14.

249 Hediger, M. L.,Overpeck, M. D.,Ruan, W. J., Troendle, J. F. Early infant feeding and growth status of US-born infants and children aged 4-71 mo: analyses from the third National Health and Nutrition Examination Survey, 1988-1994. Am J Clin Nutr.2000;72:159-67.

250 Hegar, B.,Dewanti, N. R.,Kadim, M.,Alatas, S.,Firmansyah, A., Vandenplas, Y. Natural evolution of regurgitation in healthy infants. Acta Paediatr.2009;98:1189-93.

251 Heine, W.,Lapsien, C. Influence of early breast milk and formula feeding on body weight in children born in Rostock since 1945. Bibl Nutr Dieta.1982:17-8.

252 Herbst, A.,Diethelm, K.,Cheng, G.,Alexy, U.,Icks, A.,Buyken, A. E. Direction of associations between added sugar intake in early childhood and body mass index at age 7 years may depend on intake levels. J Nutr.2011;141:1348-54.

253 Hess,S. Y.,Abbeddou,S.,Jimenez,E. Y.,Somé,J. W.,Vosti,S. A.,Ouédraogo,Z. P.,Guissou,R. M.,Ouédraogo,J. B.,Brown,K. $\mathrm{H}$. Small-quantity lipid-based nutrient supplements, regardless of their zinc content, increase growth and reduce the prevalence of stunting and Wasting in young burkinabe children: A cluster-randomized trial. PLoS ONE.2015;10.

254 Hettiarachchi,M.,Lekamwasam,S.,Liyanage,C. Long-term cereal-based nutritional supplementation improved the total spine bone mineral density amongst Sri Lankan preschool children: a randomized controlled study. J Pediatr Endocrinol Metab.2010;23:555-63.

255 Hijazi, S. S.,Abulaban, A.,Waterlow, J. C. The duration for which exclusive breast-feeding is adequate. A study in Jordan. Acta Paediatr Scand.1989;78:23-8.

256 Hillis, S. D.,Weigle, K.,Miranda, C. M.,McCann, M.,Bender, D.,Stewart, P. Supplementary feeding in Colombian child-care centers and growth velocity. Pediatrics.1994;94:1066-9.

Design, IV DV

IV

IV

V

\section{IV, DV}

Design

IV, Country

\section{IV, Age}

IV

IV

IV 


\begin{tabular}{|c|c|c|}
\hline 258 & $\begin{array}{l}\text { Hitchcock, N. E.,McGuiness, D.,Gracey, M. Growth and feeding practices of Western Australian infants. Med J } \\
\text { Aust.1982;1:372-6. }\end{array}$ & $\begin{array}{l}\text { Design, IV, } \\
\text { DV, Date }\end{array}$ \\
\hline 259 & Hitchcock, N. E.,Owles, E. N.,Gracey, M. Breast feeding and growth of healthy infants. Med J Aust.1981;2:536-7. & IV, DV, Date \\
\hline 260 & $\begin{array}{l}\text { Hoffman, D. R.,Garfield, S.,Morale, S. E.,Bosworth, R. G.,Castaneda, Y. S.,Wheaton, D. K. H., Theuer, R. C.,Birch, E. E. } \\
\text { Visual and neural development of breast-fed infants receiving docosahexaenoic acid (dha)-enriched baby food: a } \\
\text { randomized clinical trial. Iovs.2004;45:ARVO E-abstract } 3510 .\end{array}$ & Design \\
\hline 261 & $\begin{array}{l}\text { Hokama,T. Levels of serum ferritin and total body iron among infants with different feeding regimens. Acta Paediatr } \\
\text { Jpn.1993;35:298-301. }\end{array}$ & IV, DV \\
\hline 262 & $\begin{array}{l}\text { Holgerson PL,Vestman NR,Claesson R,Ohman C,Domellof M,Tanner AC,Hernell O,Johansson I. Oral microbial profile } \\
\text { discriminates breast-fed from formula-fed infants. J Pediatr Gastroenterol Nutr.2013;56:127-36. }\end{array}$ & $\begin{array}{l}\text { Design, IV, } \\
\text { DV }\end{array}$ \\
\hline 263 & $\begin{array}{l}\text { Hop le, T.,Berger, J. Multiple micronutrient supplementation improves anemia, micronutrient nutrient status, and growth of } \\
\text { Vietnamese infants: double-blind, randomized, placebo-controlled trial. J Nutr.2005;135:660s-665s. }\end{array}$ & IV \\
\hline 264 & $\begin{array}{l}\text { Hop, L. T.,Gross, R.,Giay, T.,Sastroamidjojo, S.,Schultink, W.,Lang, N. T. Premature complementary feeding is associated } \\
\text { with poorer growth of vietnamese children. J Nutr.2000;130:2683-90. }\end{array}$ & Country \\
\hline 265 & $\begin{array}{l}\text { Hop, L. T.,Gross, R.,Giay, T.,Schultink, W.,Thuan, B. T.,Sastroamidjojo, S. Longitudinal observation of growth of } \\
\text { Vietnamese children in Hanoi, Vietnam from birth to } 10 \text { years of age. Eur J Clin Nutr.1997;51:164-71. }\end{array}$ & IV, DV \\
\hline 266 & $\begin{array}{l}\text { Hopkins, D.,Steer, C. D.,Northstone, K.,Emmett, P. M. Effects on childhood body habitus of feeding large volumes of cow } \\
\text { or formula milk compared with breastfeeding in the latter part of infancy. Am J Clin Nutr.2015;102:1096-103. }\end{array}$ & IV \\
\hline 267 & $\begin{array}{l}\text { Hopkins,D.,Emmett,P.,Steer,C.,Rogers,I.,Noble,S.,Emond,A. Infant feeding in the second } 6 \text { months of life related to iron } \\
\text { status: an observational study. Arch Dis Child.2007;92:850-4. }\end{array}$ & DV \\
\hline 268 & $\begin{array}{l}\text { Hoppe, C.,Molgaard, C., Thomsen, B. L.,Juul, A.,Michaelsen, K. F. Protein intake at } 9 \text { mo of age is associated with body } \\
\text { size but not with body fat in 10-y-old Danish children. Am J Clin Nutr.2004;79:494-501. }\end{array}$ & IV \\
\hline 269 & $\begin{array}{l}\text { Horodynski, M. A.,Baker, S.,Van Egeren, L.,Olson, B.,Brophy-Herb, H.,Auld, G. The healthy babies curriculum. J Nutr } \\
\text { Educ Behav.2014;46:151-2. }\end{array}$ & Design, IV \\
\hline 270 & $\begin{array}{l}\text { Horta, B. L.,Bas, A.,Bhargava, S. K.,Fall, C. H.,Feranil, A.,de Kadt, J.,Martorell, R.,Richter, L. M.,Stein, A. D.,Victora, C. G. } \\
\text { Infant feeding and school attainment in five cohorts from low- and middle-income countries. PLoS One.2013;8:e71548. }\end{array}$ & Design \\
\hline 271 & Horwood, L. J.,Fergusson, D. M. Breastfeeding and later cognitive and academic outcomes. Pediatrics.1998;101:E9. & IV \\
\hline 272 & $\begin{array}{l}\text { Hosaka, M.,Asayama, K.,Staessen, J. A.,Ohkubo, T.,Hayashi, K., Tatsuta, N.,Kurokawa, N.,Satoh, M.,Hashimoto, } \\
\text { T.,Hirose, T.,Obara, T.,Metoki, H.,Inoue, R.,Kikuya, M.,Nakai, K.,Imai, Y.,Satoh, H. Breastfeeding leads to lower blood } \\
\text { pressure in 7-year-old Japanese children: Tohoku Study of Child Development. Hypertens Res.2013;36:117-22. }\end{array}$ & IV, DV \\
\hline 273 & $\begin{array}{l}\text { Hudara S,Mimouni F,Rachman Y,Dayan B,Silbermintz A,Turner D. Retrospective cohort study of a new infant formula } \\
\text { during the first } 6 \text { months of life: reflections on growth curves, human milk and formula feeding. Isr Med Assoc } \\
\text { J.2010;12:676-80. }\end{array}$ & IV \\
\hline
\end{tabular}




\begin{tabular}{|c|c|c|}
\hline 274 & $\begin{array}{l}\text { Hurley, K. M.,Black, M. M. Introduction to a supplement on responsive feeding: promoting healthy growth and development } \\
\text { for infants and toddlers. J Nutr.2011;141:489. }\end{array}$ & Design \\
\hline 275 & $\begin{array}{l}\text { Husaini, M. A.,Karyadi, L.,Husaini, Y. K.,Sandjaja,,Karyadi, D.,Pollitt, E. Developmental effects of short-term supplementary } \\
\text { feeding in nutritionally-at-risk Indonesian infants. Am J Clin Nutr.1991;54:799-804. }\end{array}$ & Country \\
\hline 276 & $\begin{array}{l}\text { Inostroza, J.,Haschke, F.,Steenhout, P.,Grathwohl, D.,Nelson, S. E.,Ziegler, E. E. Low-protein formula slows weight gain in } \\
\text { infants of overweight mothers. J Pediatr Gastroenterol Nutr.2014;59:70-7. }\end{array}$ & IV \\
\hline 277 & $\begin{array}{l}\text { Isherwood,R. J.,Dimond,C.,Longhurst,S. Breast feeding and weaning practices in relation to nutritional status of under-5 } \\
\text { children in north Bangladesh. J Trop Pediatr.1988;34:28-31. }\end{array}$ & Design \\
\hline 278 & $\begin{array}{l}\text { Islam, M. M.,Peerson, J. M.,Ahmed, T.,Dewey, K. G.,Brown, K. H. Effects of varied energy density of complementary foods } \\
\text { on breast-milk intakes and total energy consumption by healthy, breastfed Bangladeshi children. Am J Clin } \\
\text { Nutr.2006;83:851-8. }\end{array}$ & IV, DV \\
\hline 279 & $\begin{array}{l}\text { Jackson, D. A.,Imong, S. M.,Wongsawasdii, L.,Silprasert, A.,Preunglampoo, S.,Leelapat, P.,Drewett, R. F.,Amatayakul, } \\
\text { K.,Baum, J. D. Weaning practices and breast-feeding duration in Northern Thailand. Br J Nutr.1992;67:149-64. }\end{array}$ & IV, DV \\
\hline 280 & $\begin{array}{l}\text { Jackson,M. I. Early childhood WIC participation, cognitive development and academic achievement. Soc Sci } \\
\text { Med.2015;126:145-53. }\end{array}$ & IV \\
\hline 281 & $\begin{array}{l}\text { Jacobson, S. W.,Chiodo, L. M.,Jacobson, J. L. Breastfeeding effects on intelligence quotient in 4- and 11-year-old children. } \\
\text { Pediatrics.1999;103:e71. }\end{array}$ & IV \\
\hline 282 & $\begin{array}{l}\text { Jain,V.,Klein,B. P.,Nash,M.,Chapman-Novakofski,K. Two feasibility studies for introduction of multimicronutrient soy/whey- } \\
\text { based supplements in rural homes in Honduras. Journal of Hunger and Environmental Nutrition.2011;6:247-263. }\end{array}$ & IV \\
\hline 283 & Jansen,G.R.,O'B Hourihane. The nutritional status of preschool children in Egypt. World Rev Nutr Diet.1985;45:42-67. & Design \\
\hline 284 & $\begin{array}{l}\text { Jatanasen,A.,Sacholvicharn,V.,Ongkulna,P. An evaluation of supplementary feedings of Thai infants in urban slum } \\
\text { communities: effect on growth, health and nutritional status. J Med Assoc Thai.1983;66 Suppl 1:20-9. }\end{array}$ & $\begin{array}{l}\text { Design, } \\
\text { Health } \\
\text { status }\end{array}$ \\
\hline 285 & $\begin{array}{l}\text { Jensen, B. W.,Nichols, M.,Allender, S.,de Silva-Sanigorski, A.,Millar, L.,Kremer, P.,Lacy, K.,Swinburn, B. Inconsistent } \\
\text { associations between sweet drink intake and 2-year change in BMI among Victorian children and adolescents. Pediatr } \\
\text { Obes.2013;8:271-83. }\end{array}$ & Age \\
\hline 286 & $\begin{array}{l}\text { Jensen, S. M.,Ritz, C.,Ejlerskov, K. T.,Molgaard, C.,Michaelsen, K. F. Infant BMI peak, breastfeeding, and body } \\
\text { composition at age } 3 \text { y. Am J Clin Nutr.2015;101:319-25. }\end{array}$ & IV \\
\hline 287 & $\begin{array}{l}\text { Jensen,C. L.,Prager,T. C.,Zou,Y.,Fraley,J. K.,Maude,M.,Anderson,R. E.,Heird,W. C. Effects of maternal docosahexaenoic } \\
\text { acid supplementation on visual function and growth of breast-fed term infants. Lipids.1999;34 Suppl:S225. }\end{array}$ & Design, IV \\
\hline 288 & $\begin{array}{l}\text { Jones, G.,Hynes, K. L.,Dwyer, T. The association between breastfeeding, maternal smoking in utero, and birth weight with } \\
\text { bone mass and fractures in adolescents: a 16-year longitudinal study. Osteoporos Int.2013;24:1605-11. }\end{array}$ & IV \\
\hline 289 & $\begin{array}{l}\text { Jones, G.,Riley, M.,Dwyer, T. Breastfeeding in early life and bone mass in prepubertal children: a longitudinal study. } \\
\text { Osteoporos Int.2000;11:146-52. }\end{array}$ & IV \\
\hline
\end{tabular}


290 Jooste, P. L.,Rossouw, L. J.,Steenkamp, H. J.,Rossouw, J. E.,Swanepoel, A. S., Charlton, D. O. Effect of breast feeding on the plasma cholesterol and growth of infants. J Pediatr Gastroenterol Nutr.1991;13:139-42.

291 Joseph, N.,Unnikrishnan, B.,Naik, V. A.,Mahantshetti, N. S.,Mallapur, M. D.,Kotian, S. M.,Nelliyanil, M. Infant rearing practices in South India: a longitudinal study. J Family Med Prim Care.2013;2:37-43.

292 Joshi N,Agho KE,Dibley MJ,Senarath U,Tiwari K. Determinants of inappropriate complementary feeding practices in young children in Nepal: secondary data analysis of Demographic and Health Survey 2006. Matern Child Nutr.2012;8 Suppl 1:4559.

293 Juez, G.,Diaz, S.,Casado, M. E.,Duran, E.,Salvatierra, A. M.,Peralta, O.,Croxatto, H. B. Growth pattern of selected urban Chilean infants during exclusive breast-feeding. Am J Clin Nutr.1983;38:462-8.

294 Jung, E.,Czajka-Narins, D. M. Birth weight doubling and tripling times: an updated look at the effects of birth weight, sex race and type of feeding. Am J Clin Nutr.1985;42:182-9.

295 Kagura, J.,Feeley, A. B.,Micklesfield, L. K.,Pettifor, J. M.,Norris, S. A. Association between infant nutrition and

296 Kainonen E,Rautava S,Isolauri E. Immunological programming by breast milk creates an anti-inflammatory cytokine milieu in breast-fed infants compared to formula-fed infants. Br J Nutr.2013;109:1962-70.

297 Kajantie, E.,Barker, D. J.,Osmond, C.,Forsen, T.,Eriksson, J. G. Growth before 2 years of age and serum lipids 60 years later: the Helsinki Birth Cohort study. Int J Epidemiol.2008;37:280-9.

298 Kallio, M. J.,Salmenpera, L.,Siimes, M. A.,Perheentupa, J.,Miettinen, T. A. Tracking of serum cholesterol and lipoprotein levels from the first year of life. Pediatrics.1993;91:949-54.

299 Kallio,M. J.,Salmenpera,L.,Siimes,M. A.,Perheentupa,J.,Miettinen,T. A. Exclusive breast-feeding and weaning: effect on serum cholesterol and lipoprotein concentrations in infants during the first year of life. Pediatrics.1992;89:663-6.

300 Karaolis-Danckert, N.,Buyken, A. E.,Kulig, M.,Kroke, A.,Forster, J.,Kamin, W.,Schuster, A.,Hornberg, C.,Keil, T.,Bergmann, R. L.,Wahn, U.,Lau, S. How pre- and postnatal risk factors modify the effect of rapid weight gain in infancy and early childhood on subsequent fat mass development: results from the Multicenter Allergy Study 90 . Am J Clin Nutr.2008;87:1356-64.

301 Karlsland Akeson, P. K.,Axelsson, I. E.,Raiha, N. C.,Warm, A.,Minoli, I.,Moro, G. Protein intake and metabolism in formulafed infants given Swedish or Italian weaning foods. Acta Paediatr.2000;89:158-64.

302 Karlsson Videhult, F.,Ohlund, I.,Stenlund, H.,Hernell, O.,West, C. E. Probiotics during weaning: a follow-up study on effects on body composition and metabolic markers at school age. Eur J Nutr.2015;54:355-63.

303 Kattelmann,K. K.,Ho,M.,Specker,B. L. Effect of timing of introduction of complementary foods on iron and zinc status of formula fed infants at 12, 24, and 36 months of age. J Am Diet Assoc.2001;101:443-7. 
306 Kersting, M.,Alexy, U.,Sichert-Hellert, W.,Manz, F.,Schoch, G. Measured consumption of commercial infant food products in German infants: results from the DONALD study. Dortmund Nutritional and Anthropometrical Longitudinally Designed. J Pediatr Gastroenterol Nutr.1998;27:547-52.

307 Kesaree, N.,Shivamurty, K. S.,Prakash, B. S.,Ramachandra,,Haridas, C. K. Feeding pattern of infants in Devangere. Indian J Pediatr.1981;48:281-4.

$308 \quad$ Khaldi, F.,Bouguerra, F. Feeding practices, growth, and morbidity in Tunisia. Pediatrics.2000;106:1275-6.

309 Khan, A. I.,Kabir, I.,Hawkesworth, S.,Ekström, E. C.,Arifeen, S.,Frongillo, E. A.,Persson, L. A. Early invitation to food and/or Date multiple micronutrient supplementation in pregnancy does not affect body composition in offspring at 54 months: Follow-up of the MINIMat randomised trial, Bangladesh. Maternal and Child Nutrition.2015;11:385-397.

310 Khan, M. U. Breastfeeding, growth and diarrhoea in rural Bangladesh children. Hum Nutr Clin Nutr.1984;38:113-9.

IV

311

312 Kholdi N,Zayeri F,Bagheban AA,Khodakarim S,Ramezankhani A. A study of growth failure and its related factors in
children from 0 to 2 years in Tehran, Iran. Turk J Pediatr.2012;54:38-44.

313

Kiefte-de Jong, J. C.,de Vries, J. H.,Escher, J. C.,Jaddoe, V. W.,Hofman, A

Kiefte-de Jong, J. C.,de Vries, J. H.,Escher, J. C.,Jaddoe, V. W.,Hofman, A.,Raat, H.,Moll, H. A. Role of dietary patterns sedentary behaviour and overweight on the longitudinal development of childhood constipation: the Generation $R$ study. Matern Child Nutr.2013;9:511-23.

314 Kilaru, A.,Griffiths, P. L.,Ganapathy, S.,Ghosh, S. Community-based nutrition education for improving infant growth in rural Karnataka. Indian Pediatr.2005;42:425-32.

315 King,S.,Prawitz,A. D.,Umoren,J.,O'Gorman,T. The impact of high diastase malted barley flour on weight and height of malnourished children in Panama. Journal of Hunger and Environmental Nutrition.2007;1:23-35.

316 Klag, E. A.,McNamara, K.,Geraghty, S. R.,Keim, S. A. Associations Between Breast Milk Feeding, Introduction of Solid Foods, and Weight Gain in the First 12 Months of Life. Clin Pediatr (Phila).2015;54:1059-67. Kleinman, R. E. Complementary feeding and neuromuscular development. Pediatrics.2000;106:1279.

318 Kolacek, S.,Kapetanovic, T.,Zimolo, A.,Luzar, V. Early determinants of cardiovascular risk factors in adults. A. Plasma lipids. Acta Paediatr.1993;82:699-704.

319 Koletzko, B.,Dokoupil, K.,Reitmayr, S.,Weimert-Harendza, B.,Keller, E. Dietary fat intakes in infants and primary school DV children in Germany. Am J Clin Nutr.2000;72:1392s-1398s.

320 Koletzko, B.,von Kries, R.,Closa, R.,Escribano, J.,Scaglioni, S.,Giovannini, M.,Beyer, J.,Demmelmair, H.,Anton, B.,Gruszfeld, D.,Dobrzanska, A.,Sengier, A.,Langhendries, J. P.,Rolland Cachera, M. F.,Grote, V. Can infant feeding
IV, DV

Design, IV 
321 Koletzko, B.,von Kries, R.,Closa, R.,Escribano, J.,Scaglioni, S.,Giovannini, M.,Beyer, J.,Demmelmair, H.,Gruszfeld, D.,Dobrzanska, A.,Sengier, A.,Langhendries, J. P.,Rolland Cachera, M. F.,Grote, V. Lower protein in infant formula is associated with lower weight up to age 2 y: a randomized clinical trial. Am J Clin Nutr.2009;89:1836-45.

322 Koletzko, B. Complementary foods and the development of food allergy. Pediatrics.2000;106:1285.

323 Konstantynowicz, J.,Nguyen, T. V.,Kaczmarski, M.,Jamiolkowski, J.,Piotrowska-Jastrzebska, J.,Seeman, E. Fractures during growth: potential role of a milk-free diet. Osteoporos Int.2007;18:1601-7.

324 Kramer, M. S.,Fombonne, E.,Matush, L.,Bogdanovich, N.,Dahhou, M.,Platt, R. W. Long-term behavioural consequences of infant feeding: the limits of observational studies. Paediatr Perinat Epidemiol.2011;25:500-6.

325 Kramer, M. S.,Guo, T.,Platt, R. W.,Shapiro, S.,Collet, J. P.,Chalmers, B.,Hodnett, E.,Sevkovskaya, Z.,Dzikovich, I.,Vanilovich, I. Breastfeeding and infant growth: biology or bias?. Pediatrics.2002;110:343-7.

326 Kramer, M. S.,Moodie, E. E.,Dahhou, M.,Platt, R. W. Breastfeeding and infant size: evidence of reverse causality. Am J Epidemiol.2011;173:978-83.

327 Kramer, M. S.,Moodie, E. E.,Platt, R. W. Infant feeding and growth: can we answer the causal question?. Epidemiology.2012;23:790-4.

$328 \quad$ Kramer, M. S. Do breast-feeding and delayed introduction of solid foods protect against subsequent obesity?. J Pediatr.1981;98:883-7.

329 Krebs,N. F. Culbertson D. L. Westcott J. L. Sherlock L. Hambidge K. M. Normal Iron Status in Breastfed Infants Consuming Meat as an Early Complementary Food. Pediatric Academic Societies Annual Meeting.2011.

330 Krebs,N. F.,Hambidge,K. M.,Westcott,J. E.,Miller,L. V.,Sian,L.,Bell,M.,Grunwald,G. Exchangeable zinc pool size in infants is related to key variables of zinc homeostasis. J Nutr.2003;133:1498s-501s.

331 Krebs,N. F.,Mazariegos,M.,Chomba,E.,Sami,N.,Pasha,O., Tshefu,A.,Carlo,W. A.,Goldenberg,R. L.,Bose,C. L.,Wright,L. L.,Koso-Thomas,M.,Goco,N.,Kindem,M.,McClure,E.

M.,Westcott,J.,Garces,A.,Lokangaka,A.,Manasyan,A.,Imenda,E.,Hartwell,T. D.,Hambidge,K. M. Randomized controlled trial of meat compared with multimicronutrient-fortified cereal in infants and toddlers with high stunting rates in diverse settings. Am J Clin Nutr.2012;96:840-7.

332 Krebs,N. F.,Westcott,J. E.,Culbertson,D. L.,Sian,L.,Miller,L. V.,Hambidge,K. M. Comparison of complementary feeding strategies to meet zinc requirements of older breastfed infants. Am J Clin Nutr.2012;96:30-5.

333 Kronborg, H.,Foverskov, E.,Vaeth, M. Predictors for early introduction of solid food among Danish mothers and infants: an observational study. BMC Pediatr.2014;14:243.

334 Kuklina, E. V.,Ramakrishnan, U.,Stein, A. D.,Barnhart, H. H.,Martorell, R. Growth and diet quality are associated with the attainment of walking in rural Guatemalan infants. J Nutr.2004;134:3296-300.

335 Kumar, V.,Sharma, S.,Khanna, P.,Vanaja, K. Breast vs bottle feeding-impact on growth in urban infants. Indian J 
336 Kusin, J. A., Kardjati, S.,van Steenbergen, W. M.,Renqvist, U. H. Nutritional transition during infancy in East Java, Indonesia: 2. A longitudinal study of growth in relation to the intake of breast milk and additional foods. Eur $\mathrm{J}$ Clin Nutr.1991;45:77-84

337 Kusin, J. A.,Kardjati, S.,van Steenbergen, W. Traditional infant feeding practices: right or wrong?. Soc Sci Med.1985;21:283-6.

338 Kwok, M. K.,Leung, G. M.,Lam, T. H.,Schooling, C. M. Breastfeeding, childhood milk consumption, and onset of puberty. Pediatrics.2012;130:e631-9.

339 Laitinen,K.,Kalliomaki,M.,Poussa,T.,Lagstrom,H.,Isolauri,E. Evaluation of diet and growth in children with and without atopic eczema: follow-up study from birth to 4 years. Br J Nutr.2005;94:565-74.

$340 \quad$ Lampe,J. B.,Velez,N. The effect of prolonged bottle feeding on cow's milk intake and iron stores at 18 months of age. Clin Pediatr (Phila).1997;36:569-72.

341 Lang B,Moynihan P. The weaning diet: promoting growth while safeguarding dental health. Quintessence Int.2006;37:6326.

342 Larnkjaer, A.,Hoppe, C.,Molgaard, C.,Michaelsen, K. F. The effects of whole milk and infant formula on growth and IGF-I in late infancy. Eur J Clin Nutr.2009;63:956-63.

343 Lasky, P. A.,Eichelberger, K. M. Implications, considerations, and nursing interventions of obesity in neonatal and preschool patients. Nurs Clin North Am.1982;17:199-205.

344 Lauzon-Guillain, Bd,Wijndaele, K.,Clark, M.,Acerini, C. L.,Hughes, I. A., Dunger, D. B.,Wells, J. C.,Ong, K. K. Breastfeeding and infant temperament at age three months. PLoS One.2012;7:e29326.

345 Lawlor, D. A.,Riddoch, C. J.,Page, A. S.,Andersen, L. B.,Wedderkopp, N.,Harro, M.,Stansbie, D.,Smith, G. D. Infant feeding and components of the metabolic syndrome: findings from the European Youth Heart Study. Arch Dis Child.2005;90:5828.

$346 \quad$ Lee, K. Crying and behavior pattern in breast- and formula-fed infants. Early Hum Dev.2000;58:133-40.

347 Leermakers, E. T.,Kiefte-de Jong, J. C.,Hofman, A.,Jaddoe, V. W.,Franco, O. H. Lutein intake at the age of 1 year and cardiometabolic health at the age of 6 years: the Generation R Study. Br J Nutr.2015;114:970-8.

348 Legovic, M.,Ostric, L. The effects of feeding methods on the growth of the jaws in infants. ASDC J Dent Child.1991;58:253-5.

349 Lei, D. L.,Chaves, S. P.,Paes, A. T.,Escuder, M. M.,Ribeiro, A. B.,Freire, R. D.,Lerner, B. R. Risk of linear growth retardation during the first two years of life: a new approach. Eur J Clin Nutr.1999;53:456-60.

350 Leonard, W. R.,Dewalt, K. M.,Stansbury, J. P.,McCaston, M. K. Influence of dietary quality on the growth of highland and coastal Ecuadorian children. Am J Hum Biol.2000;12:825-837. DV

DV

IV, DV

Design

Design

IV

Design

Design, IV

IV

IV

Design, IV, DV

IV

IV 
351 Leroy, J. L.,Ruel, M.,Habicht, J. P.,Frongillo, E. A. Using height-for-age differences (HAD) instead of height-for-age z-

scores (HAZ) for the meaningful measurement of population-level catch-up in linear growth in children less than 5 years of age. BMC Pediatr.2015;15:145.

352 Leung, S. S.,Peng, C. X.,Xu, Y. Y.,Liu, K. M.,Quan, X. J.,Lui, S.,Davies, D. P. Comparative study of growth of Chinese IV, DV infants: Hong Kong versus Guangzhou. J Trop Pediatr.1994;40:166-71.

353 Leung,S.,Davies,D. P. Infant feeding and growth of Chinese infants: birth to 2 years. Paediatr Perinat Epidemiol.1994;8:301-13.

354 Leventakou, V.,Roumeliotaki, T.,Koutra, K., Vassilaki, M.,Mantzouranis, E.,Bitsios, P.,Kogevinas, M.,Chatzi, L. Breastfeeding duration and cognitive, language and motor development at 18 months of age: Rhea mother-child cohort in Crete, Greece. J Epidemiol Community Health.2015;69:232-9.

355 Li, C.,Kaur, H.,Choi, W. S.,Huang, T. T.,Lee, R. E.,Ahluwalia, J. S. Additive interactions of maternal prepregnancy BMI and breast-feeding on childhood overweight. Obes Res.2005;13:362-71.

356 Li, R.,Magadia, J.,Fein, S. B.,Grummer-Strawn, L. M. Risk of bottle-feeding for rapid weight gain during the first year of life. Arch Pediatr Adolesc Med.2012;166:431-6.

357 Lin, S. L.,Leung, G. M.,Lam, T. H.,Schooling, C. M. Timing of solid food introduction and obesity: Hong Kong's "children of 1997" birth cohort. Pediatrics.2013;131:e1459-67.

358 Lind,T.,Lonnerdal,B.,Persson,L. A.,Stenlund,H.,Tennefors,C.,Hernell,O. Effects of weaning cereals with different phytate contents on hemoglobin, iron stores, and serum zinc: a randomized intervention in infants from 6 to 12 mo of age. Am J Clin Nutr.2003;78:168-75.

359 Livingstone V. Failure to thrive while breastfeeding. Breastfeed Med.2006;1:108-11.

360 Lozoff, B.,De Andraca, I.,Castillo, M.,Smith, J. B.,Walter, T.,Pino, P. Behavioral and developmental effects of preventing iron-deficiency anemia in healthy full-term infants. Pediatrics.2003;112:846-54.

361 Lucas, R.,Judge, M.,Sajdlowska, J.,Cong, X.,McGrath, J. M.,Brandon, D. Effect of Maternal Body Mass Index on Infant Breastfeeding Behaviors and Exclusive Direct Breastfeeding. J Obstet Gynecol Neonatal Nurs.2015;44:772-83.

362 Lutter, C. K.,Mora, J. O.,Habicht, J. P.,Rasmussen, K. M.,Robson, D. S.,Herrera, M. G. Age-specific responsiveness of weight and length to nutritional supplementation. Am J Clin Nutr.1990;51:359-64.

363 Lutter, C. K.,Mora, J. O.,Habicht, J. P.,Rasmussen, K. M.,Robson, D. S.,Sellers, S. G.,Super, C. M.,Herrera, M. G. Nutritional supplementation: effects on child stunting because of diarrhea. Am J Clin Nutr.1989;50:1-8.

364 Lutter,C. K.,Rodriguez,A.,Fuenmayor,G.,Avila,L.,Sempertegui,F.,Escobar,J. Growth and micronutrient status in children receiving a fortified complementary food. J Nutr.2008;138:379-88.

365 Luukkainen,P.,Salo,M. K.,Visakorpi,J. K.,Raiha,N. C.,Nikkari,T. Impact of solid food on plasma arachidonic and docosahexaenoic acid status of term infants at 8 months of age. J Pediatr Gastroenterol Nutr.1996;23:229-34.

366 MacCarthy, D. Psychological influences affecting growth. Health Visit.1980;53:470-6.

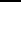

V


367 Magarey, A.,Kavian, F.,Scott, J. A.,Markow, K.,Daniels, L. Feeding Mode of Australian Infants in the First 12 Months of Life: An Assessment against National Breastfeeding Indicators. J Hum Lact.2015.

368 Maimaitiming, T.,Wang, Y. P. Feeding and intellectual development in infants and children from Uygur, Kazak, and Han nationality: A comparison of 454 cases. Journal of Clinical Rehabilitative Tissue Engineering Research.2007;11:1071010712.

369 Makrides,M.,Gould,J. F.,Gawlik,N. R.,Yelland,L. N.,Smithers,L. G.,Anderson,P. J.,Gibson,R. A. Four-year follow-up of children born to women in a randomized trial of prenatal DHA supplementation. Jama.2014;311:1802-4.

370 Male,C.,Persson,L. A.,Freeman,V.,Guerra,A.,van't Hof,M. A.,Haschke,F. Prevalence of iron deficiency in 12-mo-old infants from 11 European areas and influence of dietary factors on iron status (Euro-Growth study). Acta Paediatr.2001;90:492-8.

371 Mallan, K. M.,Fildes, A.,Magarey, A. M.,Daniels, L. A. The Relationship between Number of Fruits, Vegetables, and Noncore Foods Tried at Age 14 Months and Food Preferences, Dietary Intake Patterns, Fussy Eating Behavior, and Weight Status at Age 3.7 Years. J Acad Nutr Diet.2016;116:630-7.

372 Mallard,S. R.,Houghton,L. A.,Filteau,S.,Mullen,A.,Nieuwelink,J.,Chisenga,M.,Siame,J.,Gibson,R. S. Dietary diversity at 6 months of age is associated with subsequent growth and mediates the effect of maternal education on infant growth in urban Zambia. J Nutr.2014;144:1818-25.

373 Mamabolo, R. L.,Alberts, M.,Mbenyane, G. X.,Steyn, N. P.,Nthangeni, N. G.,Delemarre-Van De Waal, H. A.,Levitt, N. S. Feeding practices and growth of infants from birth to 12 months in the central region of the Limpopo Province of South Africa. Nutrition.2004;20:327-33.

374 Mamabolo,R. L.,Alberts,M.,Levitt,N. S.,Delemarre-van de Waal,H. A.,Steyn,N. P. Association between insulin-like growth factor-1, insulin-like growth factor-binding protein-1 and leptin levels with nutritional status in 1-3-year-old children, residing in the central region of Limpopo Province, South Africa. Br J Nutr.2007;98:762-9.

375 Mamun, A. A.,Lawlor, D. A.,O'Callaghan, M. J.,Williams, G. M.,Najman, J. M. Family and early life factors associated with changes in overweight status between ages 5 and 14 years: findings from the Mater University Study of Pregnancy and its outcomes. Int J Obes (Lond).2005;29:475-82.

376 Manjrekar, C.,Vishalakshi, M. P.,Begum, N. J.,Padma, G. N. Breast feeding ability of undernourished mothers and physical development of their infants during 0-1 year. Indian Pediatr.1985;22:801-9.

377 Marques,R. C.,Dorea,J. G.,Bernardi,J. V.,Bastos,W. R.,Malm,O. Maternal fish consumption in the nutrition transition of the Amazon Basin: growth of exclusively breastfed infants during the first 5 years. Ann Hum Biol.2008;35:363-77.

378 Marquis, G. S.,Habicht, J. P.,Lanata, C. F.,Black, R. E., Rasmussen, K. M. Association of breastfeeding and stunting in Peruvian toddlers: an example of reverse causality. Int J Epidemiol.1997;26:349-56.

379 Marquis, G. S.,Habicht, J. P.,Lanata, C. F.,Black, R. E.,Rasmussen, K. M. Breast milk or animal-product foods improve linear growth of Peruvian toddlers consuming marginal diets. Am J Clin Nutr.1997;66:1102-9.

380 Martin, R. M.,McCarthy, A.,Smith, G. D.,Davies, D. P.,Ben-Shlomo, Y. Infant nutrition and blood pressure in early adulthood: the Barry Caerphilly Growth study. Am J Clin Nutr.2003;77:1489-97. 
381 Martin, R. M.,Smith, G. D.,Mangtani, P.,Frankel, S.,Gunnell, D. Association between breast feeding and growth: the Boyd-

Orr cohort study. Arch Dis Child Fetal Neonatal Ed.2002;87:F193-201.

382 Martines, J. C.,Habicht, J. P.,Ashworth, A.,Kirkwood, B. R. Weaning in southern Brazil: is there a "weanling's dilemma"?. J Nutr.1994;124:1189-98.

383 Matsuzaki,M.,Kuper,H.,Kulkarni,B.,Radhakrishna,K. V.,Viljakainen,H., Taylor,A. E.,Sullivan,R.,Bowen,L., Tobias,J. H.,Ploubidis,G. B.,Wells,J. C.,Prabhakaran,D.,Smith,G. D.,Ebrahim,S.,Ben-Shlomo,Y.,Kinra,S. Life-course determinants of bone mass in young adults from a transitional rural community in India: The Andhra Pradesh Children and Parents Study (APCAPS). American Journal of Clinical Nutrition.2014;99:1450-1459.

384 May, A. L.,Dietz, W. H. The Feeding Infants and Toddlers Study 2008: opportunities to assess parental, cultural, and environmental influences on dietary behaviors and obesity prevention among young children. J Am Diet Assoc.2010;110:S11-5.

385 Mazariegos,M.,Hambidge,K. M.,Westcott,J. E.,Solomons,N. W.,Raboy,V.,Das,A.,Goco,N.,Kindem,M.,Wright,L. L.,Krebs,N. F. Neither a zinc supplement nor phytate-reduced maize nor their combination enhance growth of 6-to 12-month-old Guatemalan infants. J Nutr.2010;140:1041-8. $386 \quad$ McGuire, E. Breastfeeding and high maternal body mass index. Breastfeed Rev.2013;21:7-14.

Design

Country

McNeill, G. Birth weight, feeding practices and weight-for-age of Punjabi children in the UK and in the rural Punjab. Hum
Nutr Clin Nutr.1985;39:69-72.

McNeill, G. Birth weight, feeding practices and weight-for-age of Punjabi children in the UK and in the rural Punjab. Hum
Nutr Clin Nutr.1985;39:69-72.

388 Mehta KC,Specker BL,Bartholmey S,Giddens J,Ho ML. Trial on timing of introduction to solids and food type on infant growth. Pediatrics.1998;102:569-73.

389 Mei, H.,Guo, B.,Yin, B.,Liang, X.,Adair, L., Thompson, A.,Zhang, J. Interactive Effects of Early Exclusive Breastfeeding and Pre-Pregnancy Maternal Weight Status on Young Children's BMI - A Chinese Birth Cohort. PLoS One.2015;10:e0144357.

390 Meldrum,S. J.,D'Vaz,N.,Simmer,K.,Dunstan,J. A.,Hird,K.,Prescott,S. L. Effects of high-dose fish oil supplementation during early infancy on neurodevelopment and language: a randomised controlled trial. Br J Nutr.2012;108:1443-54.

$391 \quad$ Melnik, B. Growth and puberty in German children: is there still a positive secular trend? Consumption of milk as a vital factor in growth development..Bettina Gohlke, Woelfle JF. volume 23/2009. Deutsches Aerzteblatt International.2009;106:656-656.

392 Mennella, J. A., Castor, S. M. Sensitive period in flavor learning: effects of duration of exposure to formula flavors on food likes during infancy. Clin Nutr.2012;31:1022-5.

393 Merten, S.,Dratva, J.,Ackermann-Liebrich, U. Do baby-friendly hospitals influence breastfeeding duration on a national level?. Pediatrics.2005;116:e702-8.

394 Michaelsen, K. F.,Johansen, J. S.,Samuelson, G.,Price, P. A.,Christiansen, C. Serum bone gamma-carboxyglutamic acid protein in a longitudinal study of infants: lower values in formula-fed infants. Pediatr Res.1992;31:401-5. 


\begin{tabular}{|c|c|c|}
\hline 396 & $\begin{array}{l}\text { Michaelsen,K. F.,Milman,N.,Samuelson,G. A longitudinal study of iron status in healthy Danish infants: effects of early iron } \\
\text { status, growth velocity and dietary factors. Acta Paediatr.1995;84:1035-44. }\end{array}$ & IV, DV \\
\hline 397 & Michaelsen,K. F. Cows' milk in complementary feeding. Pediatrics.2000;106:1302-3. & Design \\
\hline 398 & Michaelsen,K. F. Nutrition and growth during infancy. The Copenhagen Cohort Study. Acta Paediatr Suppl.1997;420:1-36. & Design, IV \\
\hline 399 & $\begin{array}{l}\text { Michels, K. B.,Willett, W. C.,Graubard, B. I.,Vaidya, R. L.,Cantwell, M. M.,Sansbury, L. B.,Forman, M. R. A longitudinal } \\
\text { study of infant feeding and obesity throughout life course. Int J Obes (Lond).2007;31:1078-85. }\end{array}$ & IV \\
\hline 400 & $\begin{array}{l}\text { Mihrshahi, S.,Battistutta, D.,Magarey, A.,Daniels, L. A. Determinants of rapid weight gain during infancy: baseline results } \\
\text { from the NOURISH randomised controlled trial. BMC Pediatr.2011;11:99. }\end{array}$ & Design \\
\hline 401 & $\begin{array}{l}\text { Millar, L.,Kremer, P.,de Silva-Sanigorski, A.,McCabe, M. P.,Mavoa, H.,Moodie, M.,Utter, J.,Bell, C.,Malakellis, M.,Mathews, } \\
\text { L.,Roberts, G.,Robertson, N.,Swinburn, B. A. Reduction in overweight and obesity from a 3-year community-based } \\
\text { intervention in Australia: the 'It's Your Move!' project. Obes Rev.2011;12 Suppl 2:20-8. }\end{array}$ & IV, Age \\
\hline 402 & $\begin{array}{l}\text { Mimouni-Bloch, A.,Kachevanskaya, A.,Mimouni, F. B.,Shuper, A., Raveh, E.,Linder, N. Breastfeeding may protect from } \\
\text { developing attention-deficit/hyperactivity disorder. Breastfeed Med.2013;8:363-7. }\end{array}$ & IV \\
\hline 403 & $\begin{array}{l}\text { Mittal, S.,Gupta, M. C. Evaluation of a supplementary feeding programme through take home system. J Trop } \\
\text { Pediatr.1980;26:50-3. }\end{array}$ & IV \\
\hline 404 & $\begin{array}{l}\text { Miura T,Fukuda M,Mizuno M,Ohte N. Need for public awareness regarding low birth weight and bottle feeding. Hypertens } \\
\text { Res.2016. }\end{array}$ & Design \\
\hline 405 & $\begin{array}{l}\text { Molgaard, C.,Larnkjaer, A.,Mark, A. B.,Michaelsen, K. F. Are early growth and nutrition related to bone health in } \\
\text { adolescence? The Copenhagen Cohort Study of infant nutrition and growth. Am J Clin Nutr.2011;94:1865s-1869s. }\end{array}$ & IV \\
\hline 406 & $\begin{array}{l}\text { Moller, L. M.,de Hoog, M. L.,van Eijsden, M.,Gemke, R. J.,Vrijkotte, T. G. Infant nutrition in relation to eating behaviour and } \\
\text { fruit and vegetable intake at age } 5 \text { years. Br J Nutr.2013;109:564-71. }\end{array}$ & DV \\
\hline 407 & $\begin{array}{l}\text { Monterrosa EC,Frongillo EA,Neufeld LM,Egan KA,Ramakrishnan U,Rasmussen KM. Maternal pre-pregnancy body mass } \\
\text { index is not associated with infant and young child feeding in low-income Mexican children 1-24 months old. Matern Child } \\
\text { Nutr.2015;11:215-28. }\end{array}$ & DV \\
\hline 408 & $\begin{array}{l}\text { Monterrosa,E. C.,Frongillo,E. A.,Vasquez-Garibay,E. M.,Romero-Velarde,E.,Casey,L. M.,Willows, N. D. Predominant } \\
\text { breast-feeding from birth to six months is associated with fewer gastrointestinal infections and increased risk for iron } \\
\text { deficiency among infants. J Nutr.2008;138:1499-504. }\end{array}$ & IV \\
\hline 409 & $\begin{array}{l}\text { Monti G,Viola S,Baro C,Cresi F,Tovo PA,Moro G,Ferrero MP,Conti A,Bertino E. Tolerability of donkey's milk in } 92 \text { highly- } \\
\text { problematic cow's milk allergic children. J Biol Regul Homeost Agents.2012;26:75-82. }\end{array}$ & IV \\
\hline 410 & $\begin{array}{l}\text { Moore,S. E.,Prentice,A. M.,Wagatsuma,Y.,Fulford,A. J.,Collinson,A. C.,Raqib,R.,Vahter,M.,Persson,L. A.,Arifeen,S. E. } \\
\text { Early-life nutritional and environmental determinants of thymic size in infants born in rural Bangladesh. Acta } \\
\text { Paediatr.2009;98:1168-75. }\end{array}$ & IV, DV \\
\hline 411 & Moreno M. Early infant feeding and obesity risk. JAMA Pediatr.2014;168:1084. & Design \\
\hline
\end{tabular}




\begin{tabular}{|c|c|c|}
\hline 412 & $\begin{array}{l}\text { Morgan JB,Mumford PM. A follow-up study of nutrition and anthropometry in pre-school children. Proc Nutr } \\
\text { Soc.1980;39:5a. }\end{array}$ & Design \\
\hline 413 & $\begin{array}{l}\text { Morgan, J. B.,Lucas, A.,Fewtrell, M. S. Does weaning influence growth and health up to } 18 \text { months?. Archives of Disease } \\
\text { in Childhood: Education and Practice Edition.2004;89:728-733. }\end{array}$ & Design \\
\hline 414 & $\begin{array}{l}\text { Morley,R.,Abbott,R.,Fairweather-Tait,S.,MacFadyen,U.,Stephenson,T.,Lucas,A. Iron fortified follow on formula from } 9 \text { to } 18 \\
\text { months improves iron status but not development or growth: a randomised trial. Arch Dis Child.1999;81:247-52. }\end{array}$ & IV \\
\hline 415 & $\begin{array}{l}\text { Morrow-Tlucak, M.,Haude, R. H.,Ernhart, C. B. Breastfeeding and cognitive development in the first } 2 \text { years of life. Soc Sci } \\
\text { Med.1988;26:635-9. }\end{array}$ & IV \\
\hline 416 & Morton,R. E.,Nysenbaum,A.,Price,K. Iron status in the first year of life. J Pediatr Gastroenterol Nutr.1988;7:707-12. & DV \\
\hline 417 & $\begin{array}{l}\text { Mumford, P.,Morgan, J. B. A longitudinal study of nutrition and growth of infants initially on the upper and lower centile for } \\
\text { weight and age. Int J Obes.1982;6:335-41. }\end{array}$ & IV, DV \\
\hline 418 & $\begin{array}{l}\text { Musaad, S. M.,Donovan, S. M.,Fiese, B. H. Parental perception of child weight in the first two years-of-life: a potential link } \\
\text { between infant feeding and preschoolers' diet. Appetite.2015;91:90-100. }\end{array}$ & Design, DV \\
\hline 419 & $\begin{array}{l}\text { Nagahara, K.,Dobashi, K.,Itabashi, K. Feeding choice has a gender-associated effect on infant growth. Pediatr } \\
\text { Int.2013;55:481-7. }\end{array}$ & IV \\
\hline 420 & $\begin{array}{l}\text { Nakao, R. M. Effects of an education program on the health and illness profile of rural breast-fed babies. Philipp J } \\
\text { Nurs.1988;58:12-8. }\end{array}$ & IV \\
\hline 421 & $\begin{array}{l}\text { Narese, F.,Puccio, G.,Mazzucco, W.,Falzone, A.,Venturella, V.,Narese, D.,Capra, E. Earlier appearance of the ossification } \\
\text { center of the femoral head in breast-fed versus formula-fed infants. Nutrition.2011;27:1108-11. }\end{array}$ & Design, IV \\
\hline 422 & $\begin{array}{l}\text { Nauta,A. J.,Garssen,J. Nutritional programming of immune defense against infections in early life. Nutricia Research, } \\
\text { Utrecht, Netherlands.2014;12:113-126. }\end{array}$ & Design \\
\hline 423 & $\begin{array}{l}\text { Newman,J. E.,Garces,A.,Mazariegos,M.,Michael Hambidge,K.,Manasyan,A., Tshefu,A.,Lokangaka,A.,Sami,N.,Carlo,W. } \\
\text { A.,Bose,C. L.,Pasha,O.,Goco,N.,Chomba,E.,Goldenberg,R. L.,Wright,L. L.,Koso-Thomas,M.,Krebs,N. F. Theory-driven } \\
\text { process evaluation of a complementary feeding trial in four countries. Health Educ Res.2014;29:297-305. }\end{array}$ & Design, DV \\
\hline 424 & $\begin{array}{l}\text { Ng, S. C.,Chong, Y. S.,Rauff, M.,Myo, Z. M.,Nurfarah, C.,Deurenberg, P. R. The influence of breast feeding compared to } \\
\text { formula feeding on infant adiposity. Ann Acad Med Singapore.2004;33:S75. }\end{array}$ & Design, IV \\
\hline 425 & $\begin{array}{l}\text { Nguyen, N. D.,Allen, J. R.,Peat, J. K.,Schofield, W. N.,Nossar, V.,Eisenbruch, M.,Gaskin, K. J. Growth and feeding } \\
\text { practices of Vietnamese infants in Australia. Eur J Clin Nutr.2004;58:356-62. }\end{array}$ & IV, DV \\
\hline 426 & $\begin{array}{l}\text { Nielsen GA,Thomsen BL,Michaelsen KF. Influence of breastfeeding and complementary food on growth between } 5 \text { and } 10 \\
\text { months. Acta Paediatr.1998;87:911-7. }\end{array}$ & Design \\
\hline 427 & $\begin{array}{l}\text { Niinikoski, H.,Lagstrom, H.,Jokinen, E.,Siltala, M.,Ronnemaa, T.,Viikari, J.,Raitakari, O. T.,Jula, A.,Marniemi, J.,Nanto- } \\
\text { Salonen, K.,Simell, O. Impact of repeated dietary counseling between infancy and } 14 \text { years of age on dietary intakes and } \\
\text { serum lipids and lipoproteins: the STRIP study. Circulation.2007;116:1032-40. }\end{array}$ & IV \\
\hline
\end{tabular}


429 Novotny, R.,Coleman, P.,Tenorio, L.,Davison, N.,Camacho, T.,Ramirez, V.,Vijayadeva, V.,Untalan, P.,Tudela, M. D. Breastfeeding is associated with lower body mass index among children of the Commonwealth of the Northern Mariana Islands. J Am Diet Assoc.2007;107:1743-6.

430 Ntouva, A.,Rogers, I.,MacAdam, A.,Emmett, P. Weaning practices and iron status of exclusively breast fed infants. Journa of Human Nutrition \& Dietetics.2011;24:297-298 2p.

431 Nwaru BI,Takkinen HM,Niemela O,Kaila M,Erkkola M,Ahonen S,Haapala AM,Kenward MG,Pekkanen J,Lahesmaa R,Kere J,Simell O,Veijola R, Ilonen J,Hyoty H,Knip M,Virtanen SM. Timing of infant feeding in relation to childhood asthma and allergic diseases. J Allergy Clin Immunol.2013;131:78-86.

432 Obatolu, V. A. Growth pattern of infants fed with a mixture of extruded malted maize and cowpea. Nutrition.2003;19:174-8. Oddy, W. H.,Kendall, G. E.,Blair, E.,De Klerk, N. H.,Stanley, F. J.,Landau, L. I.,Silburn, S.,Zubrick, S. Breast feeding and cognitive development in childhood: a prospective birth cohort study. Paediatr Perinat Epidemiol.2003;17:81-90.

434 Oddy, W. H.,Robinson, M.,Kendall, G. E.,Li, J.,Zubrick, S. R.,Stanley, F. J. Breastfeeding and early child development: a prospective cohort study. Acta Paediatr.2011;100:992-9.

435 Oddy, W. H.,Sherriff, J. L. Breastfeeding, body mass index, asthma and atopy in children. Asia Pac J Public Health.2003;15 Suppl:S15-7.

436 O'Donovan,S. M.,O'B Hourihane J,Murray,D. M.,Kenny,L. C., Khashan,A. S.,Chaoimh,C. N.,Irvine,A. D.,Kiely,M. Neonatal adiposity increases the risk of atopic dermatitis during the first year of life. J Allergy Clin Immunol.2015.

437 Oelofse,A.,Van Raaij,J. M.,Benade,A. J.,Dhansay,M. A.,Tolboom,J. J.,Hautvast,J. G. The effect of a micronutrient-fortified complementary food on micronutrient status, growth and development of 6- to 12-month-old disadvantaged urban South African infants. Int J Food Sci Nutr.2003;54:399-407.

438 Ong, K. K.,Emmett, P. M.,Noble, S.,Ness, A.,Dunger, D. B. Dietary energy intake at the age of 4 months predicts postnatal weight gain and childhood body mass index. Pediatrics.2006;117:e503-8.

439 Ong, K. K.,Preece, M. A.,Emmett, P. M.,Ahmed, M. L.,Dunger, D. B. Size at birth and early childhood growth in relation to maternal smoking, parity and infant breast-feeding: longitudinal birth cohort study and analysis. Pediatr Res.2002;52:8637.

440 Onyango, A. W.,Borghi, E.,de Onis, M.,Casanovas Mdel, C.,Garza, C. Complementary feeding and attained linear growth among 6-23-month-old children. Public Health Nutr.2014;17:1975-83.

441 Ou, X.,Andres, A.,Cleves, M. A.,Pivik, R. T.,Snow, J. H.,Ding, Z.,Badger, T. M. Sex-specific association between infant diet and white matter integrity in 8-y-old children. Pediatr Res.2014;76:535-43.

442 Ounsted, M. K.,Moar, V. A.,Scott, A. Large-for-dates babies at the age of four years: health, handicap and developmental status. Early Hum Dev.1983;9:9-19. 


\begin{tabular}{|c|c|c|}
\hline 443 & $\begin{array}{l}\text { Pachucki MA. Food pattern analysis over time: unhealthful eating trajectories predict obesity. Int J Obes } \\
\text { (Lond).2012;36:686-94. }\end{array}$ & Age \\
\hline 444 & $\begin{array}{l}\text { Parry, J. E.,Ip, D. K.,Chau, P. Y.,Wu, K. M.,Tarrant, M. Predictors and consequences of in-hospital formula } \\
\text { supplementation for healthy breastfeeding newborns. J Hum Lact.2013;29:527-36. }\end{array}$ & IV, DV \\
\hline 445 & Parsons, T. J.,Power, C.,Manor, O. Infant feeding and obesity through the lifecourse. Arch Dis Child.2003;88:793-4. & IV \\
\hline 446 & $\begin{array}{l}\text { Patsourou, A.,Konstantinides, T.,Mantadakis, E.,Tsalkidis, A.,Zarras, C.,Balaska, A.,Simopoulos, K.,Chatzimichael, A. } \\
\text { Growth of exclusively breastfed and self-weaned children of Greece aged 0-36 months. Breastfeed Med.2012;7:521-5. }\end{array}$ & IV \\
\hline 447 & $\begin{array}{l}\text { Paul IM,Savage JS,Anzman SL,Beiler JS,Marini ME,Stokes JL,Birch LL. Preventing obesity during infancy: a pilot study. } \\
\text { Obesity (Silver Spring).2011;19:353-61. }\end{array}$ & IV \\
\hline 448 & Paul, A.,Whitehead, R. Infant feeding: the weighting game. Community Outlook.1986:11-7. & Design \\
\hline 449 & Paul, S. P.,Smith, B. A.,Taylor, T. M.,Walker, J. Take with a grain of salt. Clin Chem.2013;59:348-51. & Design \\
\hline 450 & $\begin{array}{l}\text { Peat,J. K.,Mihrshahi,S.,Kemp,A. S.,Marks,G. B., Tovey,E. R.,Webb,K.,Mellis,C. M.,Leeder,S. R. Three-year outcomes of } \\
\text { dietary fatty acid modification and house dust mite reduction in the Childhood Asthma Prevention Study. J Allergy Clin } \\
\text { Immunol.2004;114:807-13. }\end{array}$ & IV, DV \\
\hline 451 & $\begin{array}{l}\text { Penny,M. E.,Creed-Kanashiro,H. M.,Robert,R. C.,Narro,M. R.,Caulfield,L. E.,Black,R. E. Effectiveness of an educational } \\
\text { intervention delivered through the health services to improve nutrition in young children: a cluster-randomised controlled } \\
\text { trial. Lancet.2005;365:1863-72. }\end{array}$ & IV \\
\hline 452 & $\begin{array}{l}\text { Penrod,J. C.,Anderson,K.,Acosta,P. B. Impact on iron status of introducing cow's milk in the second six months of life. J } \\
\text { Pediatr Gastroenterol Nutr.1990;10:462-7. }\end{array}$ & IV, DV \\
\hline 453 & $\begin{array}{l}\text { Perez-Escamilla, R.,Cohen, R. J.,Brown, K. H.,Rivera, L. L.,Canahuati, J.,Dewey, K. G. Maternal anthropometric status and } \\
\text { lactation performance in a low-income Honduran population: evidence for the role of infants. Am J Clin Nutr.1995;61:528- } \\
\text { 34. }\end{array}$ & IV, DV \\
\hline 454 & Persson LA. Infant feeding and growth--a longitudinal study in three Swedish communities. Ann Hum Biol.1985;12:41-52. & IV \\
\hline 455 & $\begin{array}{l}\text { Persson,L. A.,Lundstrom,M.,Lonnerdal,B.,Hernell,O. Are weaning foods causing impaired iron and zinc status in 1-year-old } \\
\text { Swedish infants? A cohort study. Acta Paediatr.1998;87:618-22. }\end{array}$ & IV, DV \\
\hline 456 & $\begin{array}{l}\text { Peters,R. L.,Allen,K. J.,Dharmage,S. C.,Lodge,C. J.,Koplin,J. J.,Ponsonby,A. L.,Wake,M.,Lowe,A. J.,Tang,M. } \\
\text { L.,Matheson,M. C.,Gurrin,L. C. Differential factors associated with challenge-proven food allergy phenotypes in a } \\
\text { population cohort of infants: a latent class analysis. Clin Exp Allergy.2015;45:953-63. }\end{array}$ & DV \\
\hline 457 & $\begin{array}{l}\text { Pfluger M,Winkler C,Hummel S,Ziegler AG. Early infant diet in children at high risk for type } 1 \text { diabetes. Horm Metab } \\
\text { Res.2010;42:143-8. }\end{array}$ & IV \\
\hline 458 & $\begin{array}{l}\text { Pham,V. P.,Nguyen,V. H.,Salvignol,B.,Treche,S.,Wieringa,F. T.,Dijkhuizen,M. A.,Nguyen,C. K.,Pham,D. } \\
\text { T.,Schwartz,H.,Berger,J. A six-month intervention with two different types of micronutrient-fortified complementary foods }\end{array}$ & Country \\
\hline
\end{tabular}


459 Phu,P. V.,Hoan,N. V.,Salvignol,B., Treche,S.,Wieringa,F. T.,Khan,N. C., Tuong,P. D.,Berger,J. Complementary foods fortified with micronutrients prevent iron deficiency and anemia in Vietnamese infants. J Nutr.2010;140:2241-7.

460 Piemontese, P.,Gianni, M. L.,Braegger, C. P.,Chirico, G.,Gruber, C.,Riedler, J.,Arslanoglu, S.,van Stuijvenberg, M.,Boehm,

G.,Jelinek, J.,Roggero, P. Tolerance and safety evaluation in a large cohort of healthy infants fed an innovative prebiotic formula: a randomized controlled trial. PLoS One.2011;6:e28010.

461 Pimpin, L., Jebb, S., Johnson, L.,Wardle, J.,Ambrosini, G. L. Dietary protein intake is associated with body mass index and weight up to 5 y of age in a prospective cohort of twins. Am J Clin Nutr.2016;103:389-97.

462 Pivik, R. T.,Andres, A.,Badger, T. M. Effects of diet on early stage cortical perception and discrimination of syllables differing in voice-onset time: a longitudinal ERP study in 3 and 6 month old infants. Brain Lang.2012;120:27-41.

463 Pivik, R. T.,Dykman, R. A.,Jing, H.,Gilchrist, J. M.,Badger, T. M. The influence of infant diet on early developmental changes in processing human voice speech stimuli: ERP variations in breast and milk formula-fed infants at 3 and 6 months after birth. Dev Neuropsychol.2007;31:279-335.

464 Piwoz, E. G.,Black, R. E.,Lopez de Romana, G.,Creed de Kanashiro, H.,Brown, K. H. The relationship between infants' preceding appetite, illness, and growth performance and mothers' subsequent feeding practice decisions. Soc Sci Med.1994;39:851-60.

465 Piwoz, E. G.,Creed de Kanashiro, H.,Lopez de Romana, G.,Black, R. E.,Brown, K. H. Within- and between-individual variation in energy intakes by low-income Peruvian infants. Eur J Clin Nutr.1994;48:333-40.

466 Piwoz,E. G.,Lopez de Romana,G.,Creed de Kanashiro,H.,Black,R. E.,Brown,K. H. Indicators for monitoring the growth of peruvian infants: weight and length gain vs attained weight and length. Am J Public Health.1994;84:1132-8.

467 Plagemann, A.,Harder, T.,Kohlhoff, R.,Fahrenkrog, S.,Rodekamp, E.,Franke, K.,Dudenhausen, J. W. Impact of early neonatal breast-feeding on psychomotor and neuropsychological development in children of diabetic mothers. Diabetes Care.2005;28:573-8.

468 Plonka, K. A.,Pukallus, M. L.,Barnett, A.,Holcombe, T. F.,Walsh, L. J., Seow, W. K. A controlled, longitudinal study of home visits compared to telephone contacts to prevent early childhood caries. Int J Paediatr Dent.2013;23:23-31.

469 Poh,Bee Koon,Ng,Boon Koon,Siti Haslinda,Mohd Din,Nik Shanita,Safii,Wong,Jyh Eiin,Budin,Siti Balkis,Ruzita,Abd Talib,Ng,Lai Oon,Khouw,Ilse,Norimah,A. Karim. Nutritional status and dietary intakes of children aged 6 months to 12 years: findings of the Nutrition Survey of Malaysian Children (SEANUTS Malaysia). British Journal of Nutrition.2013;110:S21-35 1p.

$470 \quad$ Polańska, K.,Muszyński, P.,Sobala, W.,Dziewirska, E.,Merecz-Kot, D.,Hanke, W. Maternal lifestyle during pregnancy and child psychomotor development - Polish Mother and Child Cohort study. Early Human Development.2015;91:317-325.

471 Pollitt, E.,Gorman, K. S.,Engle, P. L.,Rivera, J. A., Martorell, R. Nutrition in early life and the fulfillment of intellectual potential. J Nutr.1995;125:1111s-1118s.

472 Pollitt, E.,Watkins, W. E.,Husaini, M. A. Three-month nutritional supplementation in Indonesian infants and toddlers

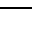

DV 


\begin{tabular}{|c|c|c|}
\hline 473 & Potur, A. H.,Kalmaz, N. An investigation into feeding errors of 0-4-month-old infants. J Trop Pediatr.1995;41:120-2. & $\begin{array}{l}\text { Design, IV, } \\
\text { DV }\end{array}$ \\
\hline 474 & Potur, A. H.,Kalmaz, N. An investigation into feeding errors of 0-4-month-old infants. J Trop Pediatr.1996;42:173-5. & $\begin{array}{l}\text { Design, IV, } \\
\text { DV }\end{array}$ \\
\hline 475 & $\begin{array}{l}\text { Prentice P,Koulman A,Matthews L,Acerini CL,Ong KK,Dunger DB. Lipidomic analyses, breast- and formula-feeding, and } \\
\text { growth in infants. J Pediatr.2015;166:276-81.e6. }\end{array}$ & IV \\
\hline 476 & $\begin{array}{l}\text { Pridham, K. F. Infant feeding and anticipatory care: supporting the adaptation of parents to their new babies. Matern Child } \\
\text { Nurs J.1981;10:111-26. }\end{array}$ & Design \\
\hline 477 & $\begin{array}{l}\text { Priego, T.,Sanchez, J.,Pico, C.,Ahrens, W.,Bammann, K.,De Henauw, S.,Fraterman, A.,Iacoviello, L.,Lissner, L.,Molnar, } \\
\text { D.,Moreno, L. A.,Siani, A.,Tornaritis, M.,Veidebaum, T.,Palou, A. Influence of breastfeeding on blood-cell transcript-based } \\
\text { biomarkers of health in children. Pediatr Obes.2014;9:463-70. }\end{array}$ & IV \\
\hline 478 & $\begin{array}{l}\text { Prodam, F.,Roccio, M.,Trovato, L.,Ricotti, R.,Moia, S.,Giglione, E.,Petri, A.,Walker, G. E.,Bellone, S.,Bona, G. Adiponectin } \\
\text { oligomers are similarly distributed in adequate-for-gestational-age obese children irrespective of feeding in their first year. } \\
\text { Pediatr Res.2015;77:808-13. }\end{array}$ & IV, DV \\
\hline 479 & $\begin{array}{l}\text { Puri, R.,Chawla, P.,Sharma, M.,Pershad, D. Impact of an on-going supplementary feeding programme on the mental } \\
\text { abilities of children. Indian J Pediatr.1984;51:653-7. }\end{array}$ & IV \\
\hline 480 & $\begin{array}{l}\text { Purwestri, R. C.,Scherbaum, V.,Inayati, D. A.,Wirawan, N. N.,Suryantan, J.,Bloem, M. A.,Pangaribuan, R. V.,Stuetz, } \\
\text { W.,Hoffmann, V.,Qaim, M.,Biesalski, H. K.,Bellows, A. C. Supplementary feeding with locally-produced Ready-to-Use Food } \\
\text { (RUF) for mildly wasted children on Nias Island, Indonesia: comparison of daily and weekly program outcomes. Asia Pac J } \\
\text { Clin Nutr.2012;21:374-9. }\end{array}$ & $\begin{array}{l}\text { Health } \\
\text { status, IV }\end{array}$ \\
\hline 481 & $\begin{array}{l}\text { Qureshi, B.,Morgan, J. B.,Kimer, A. C.,Donaldson, D.,Dickerson, J. W. Feeding practices and birth weights of infants in } \\
\text { Southall, Middlesex. J R Soc Health.1988;108:77-80. }\end{array}$ & IV, DV \\
\hline 482 & $\begin{array}{l}\text { Radhakrishna,K. V.,Hemalatha,R.,Geddam,J. J.,Kumar,P. A.,Balakrishna,N.,Shatrugna,V. Effectiveness of zinc } \\
\text { supplementation to full term normal infants: a community based double blind, randomized, controlled, clinical trial. PLoS } \\
\text { One.2013;8:e61486. }\end{array}$ & IV \\
\hline 483 & $\begin{array}{l}\text { Ramokolo, V.,Lombard, C.,Chhagan, M.,Engebretsen, I. M.,Doherty, T.,Goga, A. E.,Fadnes, L. T.,Zembe, W.,Jackson, D. } \\
\text { J.,Van den Broeck, J. Effects of early feeding on growth velocity and overweight/obesity in a cohort of HIV unexposed } \\
\text { South African infants and children. Int Breastfeed J.2015;10:14. }\end{array}$ & IV \\
\hline 484 & $\begin{array}{l}\text { Rao,S.,Rajpathak,V. Breastfeeding and weaning practices in relation to nutritional status of infants. Indian } \\
\text { Pediatr.1992;29:1533-9. }\end{array}$ & IV, DV \\
\hline 485 & Rapley, G. Talking about weaning. Community Pract.2011;84:40-1. & Design \\
\hline 486 & $\begin{array}{l}\text { Rask- } \\
\text { Nissila,L.,Jokinen,E.,Terho,P.,Tammi,A.,Hakanen,M.,Ronnemaa,T.,Viikari,J.,Seppanen,R.,Valimaki,I.,Helenius,H.,Simell,O. }\end{array}$ & IV \\
\hline
\end{tabular}


487 Ravelli, A. C., van der Meulen, J. H.,Osmond, C.,Barker, D. J.,Bleker, O. P. Infant feeding and adult glucose tolerance, lipid profile, blood pressure, and obesity. Arch Dis Child.2000;82:248-52.

488 Reifsnider, E. Reversing growth deficiency in children: the effect of a community-based intervention. J Pediatr Health Care.1998;12:305-12.

489 Requejo,A. M.,Navia,B.,Ortega,R. M.,Lopez-Sobaler,A. M.,Quintas,E.,Gaspar,M. J.,Osorio,O. The age at which meat is first included in the diet affects the incidence of iron deficiency and ferropenic anaemia in a group of pre-school children from Madrid. Int J Vitam Nutr Res.1999;69:127-31.

490 Richards, M.,Wadsworth, M.,Rahimi-Foroushani, A.,Hardy, R.,Kuh, D.,Paul, A. Infant nutrition and cognitive development in the first offspring of a national UK birth cohort. Dev Med Child Neurol.1998;40:163-7.

491 Rifas-Shiman SL,Sherry B,Scanlon K,Birch LL,Gillman MW,Taveras EM. Does maternal feeding restriction lead to childhood obesity in a prospective cohort study?. Arch Dis Child.2011;96:265-9.

492 Rios-Castillo, I.,Cerezo, S.,Corvalan, C.,Martinez, M.,Kain, J. Risk factors during the prenatal period and the first year of life associated with overweight in 7-year-old low-income Chilean children. Matern Child Nutr.2015;11:595-605.

493 Rivera,J. A.,Habicht,J. P. Effect of supplementary feeding on the prevention of mild-to-moderate wasting in conditions of endemic malnutrition in Guatemala. Bull World Health Organ.2002;80:926-32.

494 Roberts, D. W. Growth of breast fed and bottle fed infants. N Z Med J.1980;92:45-6.

495 Robinson, S. M.,Simmonds, S. J.,Jameson, K. A., Syddall, H. E.,Dennison, E. M., Cooper, C.,Sayer, A. A. Muscle strength in older community-dwelling men is related to type of milk feeding in infancy. J Gerontol A Biol Sci Med Sci.2012;67:990-6.

496 Robinson, S.,Ntani, G.,Simmonds, S.,Syddall, H.,Dennison, E.,Sayer, A. A.,Barker, D.,Cooper, C. Type of milk feeding in infancy and health behaviours in adult life: findings from the Hertfordshire Cohort Study. Br J Nutr.2013;109:1114-22.

497 Rogan, W. J.,Gladen, B. C. Breast-feeding and cognitive development. Early Hum Dev.1993;31:181-93.

498 Rolland-Cachera,M. F.,Maillot,M.,Deheeger,M.,Souberbielle,J. C.,Peneau,S.,Hercberg,S. Association of nutrition in early life with body fat and serum leptin at adult age. Int J Obes (Lond).2013;37:1116-22.

499 Rosado,J. L.,Lopez,P.,Garcia,O. P.,Alatorre,J.,Alvarado,C. Effectiveness of the nutritional supplement used in the Mexican Oportunidades programme on growth, anaemia, morbidity and cognitive development in children aged $12-24$ months. Public Health Nutr.2011;14:931-7.

500 Routi, T.,Ronnemaa, T.,Lapinleimu, H.,Salo, P.,Viikari, J.,Leino, A., Valimaki, I.,Jokinen, E., Simell, O. Effect of weaning on serum lipoprotein(a) concentration: the STRIP baby study. Pediatr Res.1995;38:522-7.

501 Rowland, M. G. The "why" and "when" of introducing food to infants: growth in young breast-fed infants and some nutritional implications. Am J Clin Nutr.1985;41:459-63. 
503 Rudnicka, A. R.,Owen, C. G.,Richards, M.,Wadsworth, M. E.,Strachan, D. P. Effect of breastfeeding and sociodemographic

IV factors on visual outcome in childhood and adolescence. Am J Clin Nutr.2008;87:1392-9.

504 Rudy,C. A. Vegetarian diets for children. Pediatr Nurs.1984;10:329-33.

Design

505 Ruel, M. T.,Rivera, J.,Habicht, J. P.,Martorell, R. Differential response to early nutrition supplementation: long-term effects on height at adolescence. Int J Epidemiol.1995;24:404-12.

506 Russell, C. G., Taki, S.,Azadi, L.,Campbell, K. J.,Laws, R.,Elliott, R.,Denney-Wilson, E. A qualitative study of the infant feeding beliefs and behaviours of mothers with low educational attainment. BMC Pediatr.2016;16:69.

507 Ryan, A. S.,Gussler, J. D. Biocultural factors affecting infant feeding and growth. Med Anthropol.1985;9:93-5.

DV

Design

508 Rzehak, P.,Sausenthaler, S.,Koletzko, S.,Reinhardt, D.,von Berg, A., Kramer, U.,Berdel, D.,Bollrath, C.,Grubl, A.,Bauer, C. P.,Wichmann, H. E.,Heinrich, J. Long-term effects of hydrolyzed protein infant formulas on growth--extended follow-up to 10 y of age: results from the German Infant Nutritional Intervention (GINI) study. Am J Clin Nutr.2011;94:1803s-1807s.

509 Saco-Pollitt, C., Triana, N.,Harahap, H.,Husaini, M.,Jahari, A. B.,Pollitt, E. The eco-cultural context of the undernourished children in a study on the effects of early supplementary feeding in Indonesia. Eur J Clin Nutr.2000;54 Suppl 2:S11-5.

510 Sacrey, L. A., Karl, J. M.,Whishaw, I. Q. Development of rotational movements, hand shaping, and accuracy in advance and withdrawal for the reach-to-eat movement in human infants aged 6-12 months. Infant Behav Dev.2012;35:543-60.

511 Saha, K. K.,Frongillo, E. A.,Alam, D. S.,Arifeen, S. E.,Persson, L. A.,Rasmussen, K. M. Appropriate infant feeding practices result in better growth of infants and young children in rural Bangladesh. Am J Clin Nutr.2008;87:1852-9.

512 Samuel, T. M.,Thomas, T.,Bhat, S.,Kurpad, A. V. Are infants born in baby-friendly hospitals being exclusively breastfed until 6 months of age?. Eur J Clin Nutr.2012;66:459-65.

513 Saner G,Dagoglu T,Uzkan I,Neyzi O. Promotion of breastfeeding in the postpartum mother. Turk J Pediatr.1985;27:63-8.

$514 \quad$ Sanger, R. G.,Bystrom, E. B. Breast feeding: does it affect oral facial growth?. Dent Hyg (Chic).1982;56:44-7.

515 Santos, I. S.,Matijasevich, A.,Assuncao, M. C.,Valle, N. C.,Horta, B. L.,Goncalves, H. D.,Gigante, D. P.,Martines, J.

C.,Pelto, G.,Victora, C. G. Promotion of Weight Gain in Early Childhood Does Not Increase Metabolic Risk in Adolescents: A 15-Year Follow-Up of a Cluster-Randomized Controlled Trial. J Nutr.2015;145:2749-55.

516 Santos,I.,Victora,C. G.,Martines,J.,Goncalves,H.,Gigante,D. P.,Valle,N. J.,Pelto,G. Nutrition counseling increases weight gain among Brazilian children. J Nutr.2001;131:2866-73.

517 Satter, Ma,Jabin, Sa,Abedin, N.,Mf, Mf,Parvin, R.,Dhali, M.,Amin, Mz. Development and Evaluation of Weaning Foods Using Locally Available Nutritious Fruits in Bangladesh. Malaysian Journal of Nutrition.2014;20:83-92.

V

济



breastfed and formula-fed infants in the first six months of life. Adv Exp Med Biol.2004;554:501-4.

519 Savino, F.,Sorrenti, M.,Benetti, S.,Lupica, M. M.,Liguori, S. A.,Oggero, R. Resistin and leptin in breast milk and infants in early life. Early Hum Dev.2012;88:779-82.

$520 \quad$ Sawley, L. Infant feeding. Nursing (Lond).1989;3:18-23. children in north India. J Health Popul Nutr.2014;32:217-26.

522 Scaglioni, S.,Agostoni, C.,Notaris, R. D.,Radaelli, G.,Radice, N.,Valenti, M.,Giovannini, M.,Riva, E. Early macronutrient intake and overweight at five years of age. Int J Obes Relat Metab Disord.2000;24:777-81.

523 Scheiwe, A.,Hardy, R.,Watt, R. G. Four-year follow-up of a randomized controlled trial of a social support intervention on infant feeding practices. Matern Child Nutr.2010;6:328-37.

525 Schmidt,M. K.,Muslimatun,S.,West,C. E.,Schultink,W.,Gross,R.,Hautvast,J. G. Nutritional status and linear growth of Indonesian infants in west java are determined more by prenatal environment than by postnatal factors. J Nutr.2002;132:2202-7.

526 Schroeder, D. G.,Martorell, R.,Rivera, J. A.,Ruel, M. T.,Habicht, J. P. Age differences in the impact of nutritional supplementation on growth. J Nutr.1995;125:1051s-1059s.

527 Schroeder, N.,Rushovich, B.,Bartlett, E.,Sharma, S.,Gittelsohn, J.,Caballero, B. Early Obesity Prevention: A Randomized Trial of a Practice-Based Intervention in 0-24-Month Infants. J Obes.2015;2015:795859.

528 Schwartz, R.,Vigo, A.,de Oliveira, L. D.,Justo Giugliani, E. R. The Effect of a Pro-Breastfeeding and Healthy Complementary Feeding Intervention Targeting Adolescent Mothers and Grandmothers on Growth and Prevalence of Overweight of Preschool Children. PLoS One.2015;10:e0131884.

529 Scott, J. A.,Binns, C. W.,Graham, K. I.,Oddy, W. H. Predictors of the early introduction of solid foods in infants: results of a cohort study. BMC Pediatr.2009;9:60.

530 Scott, J. A.,Dashti, M.,Al-Sughayer, M.,Edwards, C. A. Timing and Determinants of the Introduction of Complementary Foods in Kuwait: Results of a Prospective Cohort Study. J Hum Lact.2015;31:467-73.

531 Scully, T. Obesity. Nature.2014;508:S49.

IV

IV

Design

Country

$$
\text { IV }
$$

IV

IV

DV

\section{DV}

Design

532 Seal, N.,Broome, M. E. Prepregnancy Body Mass Index and Feeding Practices in Relation to Infants' Growth. J Nurse Pract.2013;9.

533 Seksaria,S. A., Sheth,M. K. Mass media as a means to bring about behavioral changes in infant and young child feeding practices amongst tribal mothers of Chikhli taluka, Gujarat. Indian Journal of Public Health Research and Development.2015;6:113-118. 

among Guatemalan infants. Adv Exp Med Biol.2004;554:299-301.

535 Senarath, U.,Godakandage, S. S.,Jayawickrama, H.,Siriwardena, I.,Dibley, M. J. Determinants of inappropriate complementary feeding practices in young children in Sri Lanka: secondary data analysis of Demographic and Health Survey 2006-2007. Matern Child Nutr.2012;8 Suppl 1:60-77.

536 Sethi, V.,Kashyap, S.,Seth, V. Effect of nutrition education of mothers on infant feeding practices. Indian J Pediatr.2003;70:463-6.

537 Sezer,R. G.,Aydemir,G.,Akcan,A. B.,Bayoglu,D. S.,Guran,T.,Bozaykut,A. Effect of breastfeeding on serum zinc levels and growth in healthy infants. Breastfeed Med.2013;8:159-63.

538 Shaternikov,V. A.,Fateeva,E. M.,Chernikov,M. N. Protein nutrition in early infancy and subsequent periods: its effect on further development. Bibl Nutr Dieta.1982:95-111.

539 Shehadeh, N.,Weitzer-Kish, H.,Shamir, R.,Shihab, S.,Weiss, R. Impact of early postnatal weight gain and feeding patterns on body mass index in adolescence. J Pediatr Endocrinol Metab.2008;21:9-15.

540 Shi,L.,Zhang,J.,Wang,Y.,Caulfield,L. E.,Guyer,B. Effectiveness of an educational intervention on complementary feeding practices and growth in rural China: a cluster randomised controlled trial. Public Health Nutr.2010;13:556-65.

541 Shim, J. E.,Kim, J.,Mathai, R. A. Associations of infant feeding practices and picky eating behaviors of preschool children. J Am Diet Assoc.2011;111:1363-8.

542 Simell, O.,Niinikoski, H.,Viikari, J.,Rask-Nissila, L., Tammi, A.,Ronnemaa, T. Cardiovascular disease risk factors in young children in the STRIP baby project. Special Turku coronary Risk factor Intervention Project for children. Ann Med.1999;31 Suppl 1:55-61.

543 Simondon, K. B., Gartner, A.,Berger, J.,Cornu, A., Massamba, J. P.,San Miguel, J. L.,Ly, C.,Missotte, I.,Simondon, F., Traissac, P.,Delpeuch, F.,Maire, B. Effect of early, short-term supplementation on weight and linear growth of 4-7-mo-old infants in developing countries: a four-country randomized trial. Am J Clin Nutr.1996;64:537-45.

$544 \quad$ Singhal A,Cole TJ,Fewtrell M,Kennedy K,Stephenson T,Elias-Jones A,Lucas A. Promotion of faster weight gain in infants born small for gestational age: is there an adverse effect on later blood pressure?. Circulation.2007;115:213-20.

546 Skau,J. K., Touch,B.,Chhoun,C.,Chea,M.,Unni,U. S.,Makurat,J.,Filteau,S.,Wieringa,F. T.,Dijkhuizen,M. A.,Ritz,C.,Wells,J.

547 Skledar, M. T.,Milosevic, M. Breastfeeding and time of complementary food introduction as predictors of obesity in children. Cent Eur J Public Health.2015;23:26-31.

548 Sloan, S., Gildea, A., Stewart, M.,Sneddon, H.,Iwaniec, D. Early weaning is related to weight and rate of weight gain in infancy. Child Care Health Dev.2008;34:59-64. 
549 Snijders, B. E., Thijs, C.,van Ree, R.,van den Brandt, P. A. Age at first introduction of cow milk products and other food products in relation to infant atopic manifestations in the first 2 years of life: the KOALA Birth Cohort Study.

Pediatrics.2008;122:e115-22.

550 Soto-Ramirez, N.,Karmaus, W.,Zhang, H.,Davis, S.,Agarwal, S.,Albergottie, A. Modes of infant feeding and the occurrence of coughing/wheezing in the first year of life. J Hum Lact.2013;29:71-80.

$551 \quad$ Sparks, J. W. Fetal growth and diet. Mead Johnson Symp Perinat Dev Med.1984:21-7

Design

552 Specker BL,Beck A,Kalkwarf H,Ho M. Randomized trial of varying mineral intake on total body bone mineral accretion during the first year of life. Pediatrics.1997;99:E12.

553 Spence,A. C.,Campbell,K. J.,Crawford,D. A.,McNaughton,S. A.,Hesketh,K. D. Mediators of improved child diet quality following a health promotion intervention: the Melbourne InFANT Program. Int J Behav Nutr Phys Act.2014;11:137.

554 Sreedhara, M. S.,Banapurmath, C. R. A study of nutritional status of infants in relation to their complementary feeding practices. Current Pediatric Research.2014;18:39-41.

555 Stahl, M. D.,Guida, D. A. Slow weight gain in the breast-fed infant: management options. Pediatr Nurs.1984;10:117-20, 164.

$556 \quad$ Stang,J. Improving the eating patterns of infants and toddlers. J Am Diet Assoc.2006;106:S7-9.

557 Stifter, C. A.,Anzman-Frasca, S.,Birch, L. L.,Voegtline, K. Parent use of food to soothe infant/toddler distress and child weight status. An exploratory study. Appetite.2011;57:693-9.

558 Strbak, V.,Skultetyova, M.,Hromadova, M.,Randuskova, A.,Macho, L. Late effects of breast-feeding and early weaning: seven-year prospective study in children. Endocr Regul.1991;25:53-7.

559 Stuff, J. E.,Garza, C.,Boutte, C.,Fraley, J. K.,Smith, E. O.,Klein, E. R.,Nichols, B. L. Sources of variance in milk and caloric intakes in breast-fed infants: implications for lactation study design and interpretation. Am J Clin Nutr.1986;43:361-6.

560 Stuff, J. E.,Nichols, B. L. Nutrient intake and growth performance of older infants fed human milk. J Pediatr.1989;115:95968

561 Stunkard, A. J.,Berkowitz, R. I.,Schoeller, D.,Maislin, G.,Stallings, V. A. Predictors of body size in the first 2 y of life: a highrisk study of human obesity. Int J Obes Relat Metab Disord.2004;28:503-13.

562 Stunkard, A. J.,Berkowitz, R. I.,Stallings, V. A.,Schoeller, D. A. Energy intake, not energy output, is a determinant of body size in infants. Am J Clin Nutr.1999;69:524-30.

563 Super, C. M.,Herrera, M. G.,Mora, J. O. Long-term effects of food supplementation and psychosocial intervention on the physical growth of Colombian infants at risk of malnutrition. Child Dev.1990;61:29-49.

564 Svahn,J. C.,Feldl,F.,Raiha,N. C.,Koletzko,B.,Axelsson,I. E. Different quantities and quality of fat in milk products given to young children: effects on long chain polyunsaturated fatty acids and trans fatty acids in plasma. Acta Paediatr.2002;91:20-9. 


\begin{tabular}{|c|c|c|}
\hline 565 & $\begin{array}{l}\text { Taitz, L. S.,Lukmanji, Z. Alterations in feeding patterns and rates of weight gain in South Yorkshire infants, } 1971-1977 . \\
\text { Hum Biol.1981;53:313-20. }\end{array}$ & IV, Date \\
\hline 566 & Taitz, L. Feeding children in the first year of life. Midwife Health Visitor \& Community Nurse.1990;26:81-84. & Design \\
\hline 567 & Tann, S. P.,Wheeler, E. F. Food intakes and growth of young Chinese children in London. Community Med.1980;2:20-4. & IV, DV \\
\hline 568 & $\begin{array}{l}\text { Tantracheewathorn,S.,Lohajaroensub,S. Incidence and risk factors of iron deficiency anemia in term infants. J Med Assoc } \\
\text { Thai.2005;88:45-51. }\end{array}$ & IV, DV \\
\hline 569 & $\begin{array}{l}\text { Tanzer F,Gumuser C. A study of the growth of } 200 \text { newborn babies for a period of } 6 \text { months according to the type of } \\
\text { nutrition. Ann Trop Paediatr.1989;9:54-8. }\end{array}$ & IV \\
\hline 570 & $\begin{array}{l}\text { Tarrant, M.,Fong, D. Y.,Wu, K. M.,Lee, I. L.,Wong, E. M.,Sham, A.,Lam, C.,Dodgson, J. E. Breastfeeding and weaning } \\
\text { practices among Hong Kong mothers: a prospective study. BMC Pregnancy Childbirth.2010;10:27. }\end{array}$ & DV \\
\hline 571 & $\begin{array}{l}\text { Taveras EM,Blackburn K,Gillman MW,Haines J,McDonald J,Price S,Oken E. First steps for mommy and me: a pilot } \\
\text { intervention to improve nutrition and physical activity behaviors of postpartum mothers and their infants. Matern Child } \\
\text { Health J.2011;15:1217-27. }\end{array}$ & IV \\
\hline 572 & $\begin{array}{l}\text { Tawia, S. Breastfeeding, brain structure and function, cognitive development and educational attainment. Breastfeed } \\
\text { Rev.2013;21:15-20. }\end{array}$ & Design \\
\hline 573 & Tawia, S. Childhood obesity and being breastfed. Breastfeed Rev.2013;21:42-8. & Design \\
\hline 574 & $\begin{array}{l}\text { Taylor,A.,Redworth,E. W.,Morgan,J. B. Influence of diet on iron, copper, and zinc status in children under } 24 \text { months of } \\
\text { age. Biol Trace Elem Res.2004;97:197-214. }\end{array}$ & DV \\
\hline 575 & $\begin{array}{l}\text { Thakur, R.,Singh, M. G.,Chaudhary, S.,Manuja, N. Effect of mode of delivery and feeding practices on acquisition of oral } \\
\text { Streptococcus mutans in infants. Int J Paediatr Dent.2012;22:197-202. }\end{array}$ & DV \\
\hline 576 & $\begin{array}{l}\text { Theron, M.,Amissah, A.,Kleynhans, I. C.,Albertse, E.,Maclntyre, U. E. Inadequate dietary intake is not the cause of stunting } \\
\text { amongst young children living in an informal settlement in Gauteng and rural Limpopo Province in South Africa: the } \\
\text { NutriGro study. Public Health Nutr.2007;10:379-89. }\end{array}$ & Design \\
\hline 577 & $\begin{array}{l}\text { Thomson, J. L.,Tussing-Humphreys, L. M.,Goodman, M. H. Delta Healthy Sprouts: a randomized comparative } \\
\text { effectiveness trial to promote maternal weight control and reduce childhood obesity in the Mississippi Delta. Contemp Clin } \\
\text { Trials.2014;38:82-91. }\end{array}$ & Design, IV \\
\hline 578 & $\begin{array}{l}\text { Thorisdottir, B.,Gunnarsdottir, I.,Thorisdottir, A. V.,Palsson, G. I.,Halldorsson, T. I., Thorsdottir, I. Nutrient intake in infancy } \\
\text { and body mass index at six years in two population-based cohorts recruited before and after revision of infant dietary } \\
\text { recommendations. Ann Nutr Metab.2013;63:145-51. }\end{array}$ & IV \\
\hline 579 & $\begin{array}{l}\text { Thorsdottir, I.,Gunnarsdottir, I.,Palsson, G. I. Birth weight, growth and feeding in infancy: relation to serum lipid } \\
\text { concentration in 12-month-old infants. Eur J Clin Nutr.2003;57:1479-85. }\end{array}$ & IV, DV \\
\hline 580 & $\begin{array}{l}\text { Timby, N.,Domellof, E.,Hernell, O.,Lonnerdal, B.,Domellof, M. Neurodevelopment, nutrition, and growth until } 12 \text { mo of age } \\
\text { in infants fed a low-energy, low-protein formula supplemented with bovine milk fat globule membranes: a randomized }\end{array}$ & IV \\
\hline
\end{tabular}


$581 \quad$ Townsend, E.,Pitchford, N. J. Baby knows best? The impact of weaning style on food preferences and body mass index in early childhood in a case-controlled sample. BMJ Open.2012;2:e000298.

582 Tripathy, R.,Das, R. N.,Das, M. M.,Parija, A. C. Growth in the first year in children following IAP Policy on Infant Feeding. Indian Pediatr.2000;37:1051-9.

$583 \quad$ Tulldahl, J.,Pettersson, K.,Andersson, S. W.,Hulthen, L. Mode of infant feeding and achieved growth in adolescence: early feeding patterns in relation to growth and body composition in adolescence. Obes Res.1999;7:431-7.

584 Umer, A.,Hamilton, C.,Britton, C. M.,Mullett, M. D.,John, C.,Neal, W.,Lilly, C. L. Association between Breastfeeding and Childhood Obesity: Analysis of a Linked Longitudinal Study of Rural Appalachian Fifth-Grade Children. Child Obes.2015;11:449-55.

585 Unni, J. C.,Richard, J. Growth and morbidity of breast-fed and artificially-fed infants in urban south Indian families. J Trop Pediatr.1988;34:179-81.

586 Vail, B.,Prentice, P.,Dunger, D. B.,Hughes, I. A.,Acerini, C. L.,Ong, K. K. Age at Weaning and Infant Growth: Primary Analysis and Systematic Review. Journal of Pediatrics.2015;167:317-324.e1.

587 Valman, H. B. The first year of life: feeding and feeding problems. Br Med J.1980;280:457-60.

588 van der Willik, E. M.,Vrijkotte, T. G.,Altenburg, T. M.,Gademan, M. G.,Kist-van Holthe, J. Exclusively breastfed overweight
infants are at the same risk of childhood overweight as formula fed overweight infants. Arch Dis Child.2015;100:932-7.

IV infants are at the same risk of childhood overweight as formula fed overweight infants. Arch Dis Child.2015;100: E.,Innis, S. M. Growth-curve standards and the assessment of early excess weight gain in infancy.

589 van Dijk, C. E.,Innis, S. M. Growth-curve standards and the assessment of early excess weight gain in infancy.
Pediatrics.2009;123:102-8.

$590 \quad$ van Eijsden, M.,Meijers, C. M.,Jansen, J. E.,de Kroon, M. L.,Vrijkotte, T. G. Cultural variation in early feeding pattern and maternal perceptions of infant growth. Br J Nutr.2015;114:481-8.

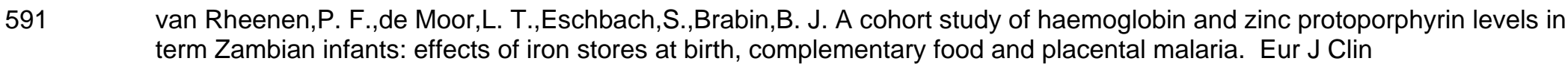

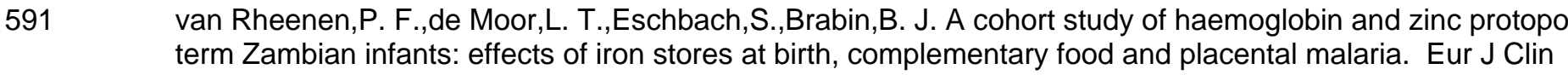
Nutr.2008;62:1379-87. van $\mathrm{t} \mathrm{Hof} \mathrm{Msc,} \mathrm{M.} \mathrm{A.} \mathrm{The} \mathrm{influence} \mathrm{of} \mathrm{breastfeeding} \mathrm{and} \mathrm{complementary} \mathrm{foods} \mathrm{on} \mathrm{growth} \mathrm{until} \mathrm{three} \mathrm{years} \mathrm{of} \mathrm{age} \mathrm{in} \mathrm{the}$

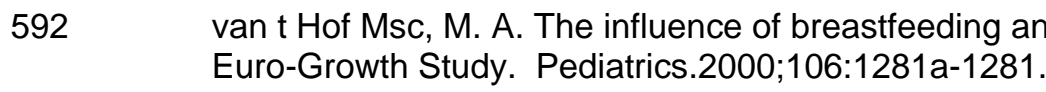

593 Vazir,S.,Engle,P.,Balakrishna,N.,Griffiths,P. L.,Johnson,S. L.,Creed-Kanashiro,H.,Fernandez Rao,S.,Shroff,M. R.,Bentley,M. E. Cluster-randomized trial on complementary and responsive feeding education to caregivers found improved dietary intake, growth and development among rural Indian toddlers. Matern Child Nutr.2013;9:99-117.

594 Veena SR,Krishnaveni GV,Srinivasan K,Wills AK,Hill JC,Kurpad AV,Muthayya S,Karat SC,Nalinakshi M,Fall CH. Infant feeding practice and childhood cognitive performance in South India. Arch Dis Child.2010;95:347-54.

595 Veena, S. R.,Krishnaveni, G. V.,Wills, A. K.,Hill, J. C., Karat, S. C.,Fall, C. H. Glucose tolerance and insulin resistance in Indian children: relationship to infant feeding pattern. Diabetologia.2011;54:2533-7. 

Metab.2014;27:1181-7.

597 Venancio, S. I.,Saldiva, S. R.,Mondini, L.,Levy, R. B.,Escuder, M. M. Early interruption of exclusive breastfeeding and associated factors, state of Sao Paulo, Brazil. J Hum Lact.2008;24:168-74.

598 Verd S,Barriuso L,Gich I,Gutierrez A,Nadal-Amat J,Carreras E. Risk of early breastfeeding cessation among symmetrical, small for gestational age infants. Ann Hum Biol.2013;40:146-51.

599 Victora, C. G.,Matijasevich, A.,Santos, I. S.,Barros, A. J.,Horta, B. L.,Barros, F. C. Breastfeeding and feeding patterns in three birth cohorts in Southern Brazil: trends and differentials. Cad Saude Publica.2008;24 Suppl 3:S409-16.

600 Victora,C. G.,Vaughan,J. P.,Martines,J. C.,Barcelos,L. B. Is prolonged breast-feeding associated with malnutrition?. Am J Clin Nutr.1984;39:307-14.

601 Villalpando, S. Feeding mode, infections, and anthropometric status in early childhood. Pediatrics.2000;106:1282-3.

\begin{tabular}{|c|c|c|}
\hline 598 & $\begin{array}{l}\text { Verd S,Barriuso L,Gich I,Gutierrez A,Nadal-Amat J,Carreras E. Risk of early breastfeeding cessation among symmetrical, } \\
\text { small for gestational age infants. Ann Hum Biol.2013;40:146-51. }\end{array}$ & $\begin{array}{l}\text { Health } \\
\text { status, DV }\end{array}$ \\
\hline 599 & $\begin{array}{l}\text { Victora, C. G.,Matijasevich, A.,Santos, I. S.,Barros, A. J.,Horta, B. L.,Barros, F. C. Breastfeeding and feeding patterns in } \\
\text { three birth cohorts in Southern Brazil: trends and differentials. Cad Saude Publica.2008;24 Suppl 3:S409-16. }\end{array}$ & IV, DV \\
\hline 600 & $\begin{array}{l}\text { Victora,C. G.,Vaughan,J. P.,Martines,J. C.,Barcelos,L. B. Is prolonged breast-feeding associated with malnutrition?. Am J } \\
\text { Clin Nutr.1984;39:307-14. }\end{array}$ & IV \\
\hline 601 & Villalpando, S. Feeding mode, infections, and anthropometric status in early childhood. Pediatrics.2000;106:1282-3. & Design \\
\hline 602 & $\begin{array}{l}\text { Virtanen, S. M.,Laara, E.,Hypponen, E.,Reijonen, H.,Rasanen, L.,Aro, A.,Knip, M.,Ilonen, J.,Akerblom, H. K. Cow's milk } \\
\text { consumption, HLA-DQB1 genotype, and type } 1 \text { diabetes: a nested case-control study of siblings of children with diabetes. } \\
\text { Childhood diabetes in Finland study group. Diabetes.2000;49:912-7. }\end{array}$ & DV \\
\hline 603 & $\begin{array}{l}\text { Virtanen, S. M.,Rasanen, L.,Ylonen, K.,Aro, A.,Clayton, D.,Langholz, B.,Pitkaniemi, J.,Savilahti, E.,Lounamaa, } \\
\text { R.,Tuomilehto, J.,et al.,. Early introduction of dairy products associated with increased risk of IDDM in Finnish children. The } \\
\text { Childhood in Diabetes in Finland Study Group. Diabetes.1993;42:1786-90. }\end{array}$ & DV \\
\hline 604 & $\begin{array}{l}\text { Vobecky,J. S.,Vobecky,J.,Shapcott,D.,Demers,P. P. Nutrient intake patterns and nutritional status with regard to relative } \\
\text { weight in early infancy. Am J Clin Nutr.1983;38:730-8. }\end{array}$ & IV \\
\hline 605 & $\begin{array}{l}\text { Wandel, M.,Fagerli, R. Aa,Olsen, P. T.,Borch-Iohnsen, B.,Ek, J. Iron status and weaning practices among Norwegian and } \\
\text { immigrant infants. Nutrition Research.1996;16:251-265. }\end{array}$ & Design \\
\hline 606 & $\begin{array}{l}\text { Wang RJ,Trehan I,LaGrone LN,Weisz AJ,Thakwalakwa CM, Maleta KM,Manary MJ. Investigation of food acceptability and } \\
\text { feeding practices for lipid nutrient supplements and blended flours used to treat moderate malnutrition. J Nutr Educ } \\
\text { Behav.2013;45:258-63. }\end{array}$ & $\begin{array}{l}\text { Health } \\
\text { status, } \\
\text { Country }\end{array}$ \\
\hline 607 & $\begin{array}{l}\text { Watt, R. G., Tull, K. I.,Hardy, R.,Wiggins, M.,Kelly, Y.,Molloy, B.,Dowler, E.,Apps, J.,McGlone, P. Effectiveness of a social } \\
\text { support intervention on infant feeding practices: randomised controlled trial. J Epidemiol Community Health.2009;63:156- } \\
62 .\end{array}$ & IV, DV \\
\hline 608 & $\begin{array}{l}\text { Weber, M.,Grote, V.,Closa-Monasterolo, R.,Escribano, J.,Langhendries, J. P.,Dain, E.,Giovannini, M.,Verduci, } \\
\text { E.,Gruszfeld, D.,Socha, P.,Koletzko, B. Lower protein content in infant formula reduces BMI and obesity risk at school age: } \\
\text { follow-up of a randomized trial. Am J Clin Nutr.2014;99:1041-51. }\end{array}$ & IV \\
\hline 609 & $\begin{array}{l}\text { Weijs, P. J.,Kool, L. M.,van Baar, N. M.,van der Zee, S. C. High beverage sugar as well as high animal protein intake at } \\
\text { infancy may increase overweight risk at } 8 \text { years: a prospective longitudinal pilot study. Nutr J.2011;10:95. }\end{array}$ & IV \\
\hline 610 & Wen, L. M.,Baur, L. A.,Simpson, J. M.,Xu, H.,Hayes, A. J.,Hardy, L. L.,Williams, M.,Rissel, C. Sustainability of Effects of an & IV \\
\hline
\end{tabular}


Early Childhood Obesity Prevention Trial Over Time: A Further 3-Year Follow-up of the Healthy Beginnings Trial. JAMA Pediatr.2015;169:543-51.

611 West, C. E.,Hernell, O.,Andersson, Y.,Sjostedt, M.,Hammarstrom, M. L. Probiotic effects on T-cell maturation in infants during weaning. Clin Exp Allergy.2012;42:540-9.

612 Westphal, R.,Phillips, G.,Irwig, L. M. Infant care and feeding in an urban black population. S Afr Med J.1981;60:778-81.

613 Weyermann, M.,Rothenbacher, D.,Brenner, H. Duration of breastfeeding and risk of overweight in childhood: a prospective birth cohort study from Germany. Int J Obes (Lond).2006;30:1281-7.

614 Wharf,S. G.,Fox,T. E.,Fairweather-Tait,S. J.,Cook,J. D. Factors affecting iron stores in infants 4-18 months of age. Eur J Design Clin Nutr.1997;51:504-9.

615 Whitehead, R. G.,Paul, A. A.,Ahmed, E. A. Weaning practices in the United Kingdom and variations in anthropometric development. Acta Paediatr Scand Suppl.1986;323:14-23.

616 Whitehead, R. G.,Paul, A. A. Infant growth and human milk requirements. A fresh approach. Lancet.1981;2:161-3.

Design, IV

617 Whitten, C. F.,Stewart, R. A. The effect of dietary sodium in infancy on blood pressure and related factors. Studies of

IV infants fed salted and unsalted diets for five months at eight months and eight years of age. Acta Paediatr Scand Suppl.1980;279:1-17.

618 Wiberger, M.,Eiben, G.,Lissner, L.,Mehlig, K.,Papoutsou, S.,Hunsberger, M. Children consuming milk cereal drink are at increased risk for overweight: The IDEFICS Sweden study, on behalf of the IDEFICS Consortium. Scand J Public Health.2014;42:518-24.

619 Wigg, N. R., Tong, S.,McMichael, A. J.,Baghurst, P. A., Vimpani, G.,Roberts, R. Does breastfeeding at six months predict cognitive development?. Aust N Z J Public Health.1998;22:232-6.

620 Wijga,A.,Vyas,U.,Vyas,A.,Sharma,V.,Pandya,N.,Nabarro,D. Feeding, illness and nutritional status of young children in rural Gujarat. Hum Nutr Clin Nutr.1983;37:255-69.

621 Williams, D. M.,Martin, R. M.,Davey Smith, G.,Alberti, K. G.,Ben-Shlomo, Y.,McCarthy, A. Associations of infant nutrition with insulin resistance measures in early adulthood: evidence from the Barry-Caerphilly Growth (BCG) study. PLoS One.2012;7:e34161.

622 Williams, J.,Wolff, A.,Daly, A.,MacDonald, A.,Aukett, A.,Booth, I. W. Iron supplemented formula milk related to reduction in psychomotor decline in infants from inner city areas: randomised study. Bmj.1999;318:693-7.

623 Winick, M. The role of early nutrition in subsequent development and optimal future health. Bull $\mathrm{N} Y$ Acad Med.1989;65:1020-5.

624 Winkelstein,M. L. Overfeeding in infancy: the early introduction of solid foods. Pediatr Nurs.1984;10:205-8, 236.

Design

DV, Date

IV

IV

Design, IV

IV, DV

Wölfle, J. Growth and puberty in German children: is there still a positive secular trend? In reply..Consumption of milk as a vital factor in growth development. Melnik B, Dtsch Arzetebl 2009, volume 206. Deutsches Aerzteblatt International.2009;106:656-656. 
627 Wright, C. M.,Parkinson, K.,Scott, J. Breast-feeding in a UK urban context: who breast-feeds, for how long and does it matter?. Public Health Nutr.2006;9:686-91.

628 Wright, M. J.,Bentley, M. E.,Mendez, M. A.,Adair, L. S. The interactive association of dietary diversity scores and breastfeeding status with weight and length in Filipino infants aged 6-24 months. Public Health Nutr.2015;18:1762-73.

629 Yew, K. S.,Webber, B.,Hodges, J.,Carter, N. J. Clinical inquiries: are there any known health risks to early introduction of solids to an infant's diet?. J Fam Pract.2009;58:219-20.

630 Young RJ,Antonson DL,Ferguson PW,Murray ND,Merkel K,Moore TE. Neonatal and infant feeding: effect on bone density at 4 years. J Pediatr Gastroenterol Nutr.2005;41:88-93.

631 Yousafzai, A. K.,Rasheed, M. A.,Rizvi, A.,Armstrong, R.,Bhutta, Z. A. Effect of integrated responsive stimulation and nutrition interventions in the Lady Health Worker programme in Pakistan on child development, growth, and health outcomes: a cluster-randomised factorial effectiveness trial. Lancet.2014;384:1282-93.

632 Ystrom, E. Breastfeeding cessation and symptoms of anxiety and depression: a longitudinal cohort study. BMC Pregnancy Childbirth.2012;12:36.

633 Zadik Z,Borondukov E,Zung A,Reifen R. Adult height and weight of breast-fed and bottle-fed Israeli infants. J Pediatr Gastroenterol Nutr.2003;37:462-7.

634 Zaman, S.,Jalil, F.,Saleemi, M. A.,Mellander, L.,Ashraf, R. N.,Hanson, L. A. Changes in feeding patterns affect growth in children 0-24 months of age living in socioeconomically different areas of Lahore, Pakistan. Adv Exp Med Biol.2002;503:49-56.

635 Zaman,S.,Ashraf,R. N.,Martines,J. Training in complementary feeding counselling of healthcare workers and its influence on maternal behaviours and child growth: a cluster-randomized controlled trial in Lahore, Pakistan. J Health Popul Nutr.2008;26:210-22.

636 Zavaleta,N.,Kvistgaard,A. S.,Graverholt,G.,Respicio,G.,Guija,H.,Valencia,N.,Lonnerdal,B. Efficacy of an MFGM-enriched complementary food in diarrhea, anemia, and micronutrient status in infants. J Pediatr Gastroenterol Nutr.2011;53:561-8.

637 Zhang,J.,Shi,L.,Chen,D. F.,Wang,J.,Wang,Y. Effectiveness of an educational intervention to improve child feeding practices and growth in rural China: updated results at 18 months of age. Matern Child Nutr.2013;9:118-29.

Country

Design

Design

Country

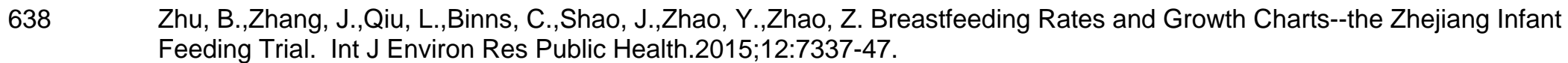

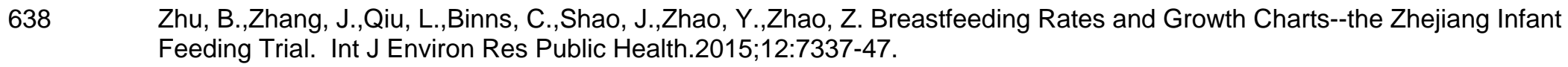
Ziegler, E. E.,Fields, D. A.,Chernausek, S. D.,Steenhout, P.,Grathwohl, D.,Jeter, J. M.,Nelson, S. E.,Haschke, F. Adequacy of Infant Formula With
Nutr.2015;61:596-603.

640 Ziegler,E. E.,Fomon,S. J.,Nelson,S. E.,Rebouche,C. J.,Edwards,B. B.,Rogers,R. R.,Lehman,L. J. Cow milk feeding in infancy: further observations on blood loss from the gastrointestinal tract. J Pediatr.1990;116:11-8. 

in 4-y-old Anglo- and Mexican-Americans. Am J Clin Nutr.1992;55:1104-8.

642 Zutavern, A.,Brockow, I.,Schaaf, B.,von Berg, A.,Diez, U.,Borte, M.,Kraemer, U.,Herbarth, O.,Behrendt, H.,Wichmann, H.

E.,Heinrich, J. Timing of solid food introduction in relation to eczema, asthma, allergic rhinitis, and food and inhalant

sensitization at the age of 6 years: results from the prospective birth cohort study LISA. Pediatrics.2008;121:e44-52 